\title{
Climate Change and Water-Related Infectious Diseases
}

\author{
Gordon Nichols ${ }^{1,2,3, *}$, Iain Lake ${ }^{3}$ and Clare Heaviside 1,4,5 $^{\text {, }}$ \\ 1 Centre for Radiation Chemicals and Environmental Hazards, Public Health England, Chilton, \\ Oxon OX11 0RQ, UK; clare.heaviside@gmail.com \\ 2 European Centre for Environment and Human Health, University of Exeter Medical School, \\ C/O Knowledge Spa RCHT, Truro, Cornwall TR1 3HD, UK \\ 3 School of Environmental Sciences, UEA, Norwich NR4 7TJ, UK; i.lake@uea.ac.uk \\ 4 School of Geography, Earth and Environmental Sciences, University of Birmingham, Edgbaston, \\ Birmingham B15 2TT, UK \\ 5 Department of Social and Environmental Health Research, London School of Hygiene and Tropical \\ Medicine, 15-17 Tavistock Place, London WC1H 9SH, UK \\ * Correspondence: Gordon.nichols@me.com
}

Received: 31 May 2018; Accepted: 10 September 2018; Published: 2 October 2018

\begin{abstract}
Background: Water-related, including waterborne, diseases remain important sources of morbidity and mortality worldwide, but particularly in developing countries. The potential for changes in disease associated with predicted anthropogenic climate changes make water-related diseases a target for prevention. Methods: We provide an overview of evidence on potential future changes in water-related disease associated with climate change. Results: A number of pathogens are likely to present risks to public health, including cholera, typhoid, dysentery, leptospirosis, diarrhoeal diseases and harmful algal blooms (HABS). The risks are greatest where the climate effects drive population movements, conflict and disruption, and where drinking water supply infrastructure is poor. The quality of evidence for water-related disease has been documented. Conclusions: We highlight the need to maintain and develop timely surveillance and rapid epidemiological responses to outbreaks and emergence of new waterborne pathogens in all countries. While the main burden of waterborne diseases is in developing countries, there needs to be both technical and financial mechanisms to ensure adequate quantities of good quality water, sewage disposal and hygiene for all. This will be essential in preventing excess morbidity and mortality in areas that will suffer from substantial changes in climate in the future.
\end{abstract}

Keywords: climate change; waterborne disease; natural environment; risks; public health; cryptosporidiosis; cholera; leptospirosis; Legionnaires' disease

\section{Introduction}

The effect of human activity on observed changes to the climate system over recent decades is widely acknowledged and is a global cause for concern. Anthropogenic (man-made) climate change has led to a rise in annual global mean temperatures since pre-industrial times, with more rapid increases since the mid-1900s [1]. As well as changing weather patterns, increasing average temperatures and, potentially of more concern, is the increase in the frequency of extreme weather events which can have enormous human cost [2]. Climate change is seen as an example of a tragedy of the Commons [3], whereby it is in the interests of individuals to benefit from human activity but the overall impact on all people collectively will be negative unless there is an agreed intervention. It is generally the case that the largest impacts on health are realised in developing regions of the world such as the tropics, whereas the greatest contributors to greenhouse gas emissions are often developed countries 
which do not suffer the consequences of extreme events to the same extent [4]. Due to the lifetime of greenhouse gases such as carbon dioxide in the atmosphere, and the timescales associated with ocean warming, even if global $\mathrm{CO}_{2}$ emissions were curtailed immediately, the effects on the earth's climate, including increasing temperatures and sea level rise would continue for a number of decades before starting to plateau [2]. However, this should be seen as a general call to action to reduce emissions as soon as possible, given that the impacts are likely to extend beyond current conditions and there are indications that economic investment now will be likely to reduce costs later [5]. There is also a need to develop adaptations to cope with changes in climate. Recent research highlighting the health benefits of limiting future temperature rises to the more ambitious target of $1.5{ }^{\circ} \mathrm{C}$ rather than $2{ }^{\circ} \mathrm{C}$, in line with the Paris agreement of 2016, further emphasises the need to limit emissions [6].

Climate change affects health in a number of ways, and the impacts vary both geographically and between different populations. A growing and ageing population in much of the world means that the proportion of the population who are vulnerable to the effects of climate change will increase in the future [7]. The most direct impacts from climate change are from the effects of high temperatures, and from acute impacts relating to extreme events such as storms, floods and heatwaves. These physical or meteorological stressors can produce direct health effects, such as physical injury, illness, or mental health impacts due to the consequences of the aftermath. In places where infrastructure or adaptation measures are poor, the impacts will be more severe [2]. In addition to these types of impact on health, climate change is likely to modify or mediate existing health effects and exacerbate inequalities through a number of indirect pathways. These more indirect effects on health occur through climate interactions with ecosystems, water, biodiversity and land use changes. Climate change can lead to environmental degradation; can affect food and water availability and quality; and increase risks to health from pathogens, vectors and infectious diseases [8]. Civil conflict or mass movement of people may be partly driven by environmental degradation and can further increase risks to health. There is evidence to suggest that climate change can be a driver for civil war $[9,10]$.

Waterborne and water-related diseases are sensitive to environmental conditions, some or all of which are likely to be affected by climate change. For example, climate change is likely to lead to changes in the frequency of heavy rainfall events, storms and drought periods [2], melting of polar ice and glaciers, warming and thermal expansion of the oceans causing sea level rise [11], and melting of permafrost, which may contribute to further warming [12]. Changes in interactions between the water cycle and the climate system will modify the risk from waterborne diseases from these physical impacts, as well as from the resulting risk of famine, water shortages, decreased water quality, increasing habitat for mosquitoes, alterations to seasonality of diseases and contaminated recreational waters. However, health impacts of waterborne disease over the longer term may be secondary to other health effects associated with other water issues (e.g., shortage, flooding, famine, the economy, sea level rise and war).

Tackling the climate change problem has focussed on mitigating the effects of greenhouse gas emissions through the Intergovernmental Panel on Climate Change (IPCC), through cross government international agreements on reducing carbon emissions and by providing reliable scientific evidence and reports. While the approach has generally been to reduce worldwide greenhouse gas emissions, the reductions are likely to be slow and work on adaptation strategies to deal with the climate change associated with overall increases in temperature is also being undertaken.

\section{Climate Change and the Water Cycle}

Even cursory examination of the evidence shows the importance of water in relation to climate change. The impact of water in the decline of civilisations has been examined and reviewed [13]. Climate change is likely to affect the water cycle across the globe [14] with potential influences on surface and groundwater quality; it will lead to changes in atmospheric water vapour content, changes in cloud types and cover, and changes in the frequency of severe storms. Over time, it is likely that there will be increased melting of glaciers and icecaps [15] and ocean warming (and associated thermal 
expansion) that will cause sea levels to rise [16]. It remains possible that the release of permafrost methane may contribute to further warming $[12,17]$. These changes in atmospheric conditions and moisture content are expected to result in an increase in floods, famine, hurricanes and tropical storms, drought [18], wild fires, chronic water shortages, decreased water quality, periods with increased mosquito vectors, alterations to the seasonality of diseases, contaminated recreational waters and rising sea levels. Most assessments of the risks to health from climate change are conducted over time periods ranging from the present to 80 years. However, there are potentially much larger risks over longer timescales, particularly if there is a substantial sea level rise, and prolonged periods with much-increased average and peak temperatures [19].

Although scientific understanding of how climate may affect weather patterns has increased enormously over the past few years, especially in relation to extreme weather, the consequences for, and influences on, water quality (e.g., microbiological quality) are far less studied [20]. Changes in water arise from interactions with the weather, affecting ecosystems, changing the flow of nutrients and pathogens in catchments, and influencing water quality. Climate change may influence the microbiological quality of river water, which may present risks to bathers [21]. A modelling approach involving Quantitative Microbial Risk Assessment found that although climate change increased the fluxes of a number of pathogens, the overall change in risk was limited. Part of this was due to the dilution effect of increasing rainfall. As risks are likely to be location specific, wider generalisations are difficult. The approach used in such studies could be transferred to other locations. In summary the IPCC states that in overall terms, climate change is projected to reduce the quality of raw waters [22].

\section{Climate Change and Drinking Water-Related Infectious Diseases}

The history of water-related disease dates back to the classical period when Empedocles is reported to have introduced drainage of a swamp (a public health intervention) to reduce disease [23]. The ability of waterborne diseases to cause large outbreaks that, in the case of typhoid and cholera, have a high morbidity and mortality, makes them important historically. A classification of water-related infections was drawn up by Bradley (Bradley's classification [24]) and has been adapted by others [25-27]. A modified-version groups diseases into waterborne; water access related; water based; water-related insect vectors; and engineered water systems, although this revision still excludes some water-related diseases (Table 1).

Drinking water is the most important waterborne disease risk because the contamination of large mains supplies can cause large outbreaks [28-32], and because small rural supplies are commonly contaminated [33,34] which, in developing countries, can lead to substantial infant mortality. Bottled water is usually safe, particularly natural mineral waters that are derived from deep wells or other secure sources, but outbreaks may occasionally occur. The water supplies on ships, trains and aircraft can be subject to contamination where the supply chain breaks down [35]. There are always potential risks when people drink untreated natural waters. The supply of clean water can become critical in areas of war, disaster, famine, drought, water shortage and flooding, and refugee supplies often need to be established rapidly to prevent outbreaks [36-41].

While climate change may affect the microbiological quality of water and water-related diseases, the arguments indicate notable uncertainty over what the specific impacts will be, and when and where they will be most acute. However, to assess the likely impacts upon the health of humans, there is a need to examine the resilience of society to changing water quality. Developing an understanding of these capabilities and adaptation potentials is key to assessing the likely influence of climate change. 
Table 1. Criteria for water-related diseases [24-26,42].

\begin{tabular}{|c|c|c|}
\hline Class & Sub-Class & Examples \\
\hline \multirow{12}{*}{ Waterborne infection } & Infectious through drinking water & $\begin{array}{l}\text { Cryptosporidium spp., Giardia spp., Vibrio cholerae, } \\
\text { Dracunculus medinensis }\end{array}$ \\
\hline & Infectious through recreational water & $\begin{array}{l}\text { Cryptosporidium, Adenovirus, Leptospira spp., } \\
\text { Naegleria fowleri }\end{array}$ \\
\hline & $\begin{array}{l}\text { Infectious through inhalation (engineered } \\
\text { systems) }\end{array}$ & Legionella pneumophila \\
\hline & Infectious through contact & Pseudomonas aeruginosa \\
\hline & Infectious through contamination of wounds & $\begin{array}{l}\text { Mycobacterium marinum, Vibrio vulnificus, } \\
\text { Aeromonas hydrophila }\end{array}$ \\
\hline & $\begin{array}{l}\text { Infectious through growth in equipment and } \\
\text { water systems }\end{array}$ & Mycobacterium avium complex \\
\hline & Infectious through growth in soil or water & Acanthamoeba spp., Burkholderia pseudomallei \\
\hline & Infectious through growth in coastal waters & Vibrio spp. \\
\hline & $\begin{array}{l}\text { Infectious from food contamination with } \\
\text { water/soil }\end{array}$ & Clostridium botulinum \\
\hline & Infectious through water contamination of food & $\begin{array}{l}\text { Cyclospora cayetanensis, Cryptosporidium spp., } \\
\text { Salmonella Typhi }\end{array}$ \\
\hline & Infections through near-drowning & Aeromonas hydrophila \\
\hline & Infectious through injection of non-sterile water & Clostridium botulinum, Clostridium novyi \\
\hline \multirow[t]{5}{*}{$\begin{array}{l}\text { Waterborne chemical or } \\
\text { toxin }\end{array}$} & Potent toxins through inhalation & Ostreopsis spp. (HABS) \\
\hline & Potent toxins through seafood & $\begin{array}{l}\text { Dinoflagellate and diatom fish and shellfish } \\
\text { poisoning (HABS) }\end{array}$ \\
\hline & Potent toxins through drinking & Cyanobacterial blooms (HABS) \\
\hline & Potent toxins through dialysis & Cyanobacterial blooms (HABS) \\
\hline & Potent toxins through recreational exposure & Cyanobacterial blooms (HABS) \\
\hline \multirow{3}{*}{$\begin{array}{l}\text { Water washed (poor } \\
\text { access) }\end{array}$} & Hygiene related & $\begin{array}{l}\text { Shigella spp., Chlamydia trachomatis, scabies, } \\
\text { pneumonia }\end{array}$ \\
\hline & Infections related to drought & Coccidioides immitis \\
\hline & Infections related to flooding & Leptospira spp. \\
\hline \multirow{3}{*}{ Water based } & $\begin{array}{l}\text { Parasite lifecycle requiring water and transmitted } \\
\text { by water }\end{array}$ & Schistosoma spp., Dracunculus medinensis \\
\hline & $\begin{array}{l}\text { Parasite lifecycle requiring water and transmitted } \\
\text { by food }\end{array}$ & $\begin{array}{l}\text { Fasciola spp., Opisthorchis sinensis, Heterophyes } \\
\text { heterophyes }\end{array}$ \\
\hline & Parasite lifecycle transmitted by waterborne route & $\begin{array}{l}\text { Dracunculus medinensis, Spirometra spp., } \\
\text { Echinococcus spp., Sarcocystis spp., Toxoplasma } \\
\text { gondii }\end{array}$ \\
\hline $\begin{array}{l}\text { Water-related insect } \\
\text { vectors }\end{array}$ & Vector breeding in water & Dengue virus, Onchocerca spp., Trypanosoma spp. \\
\hline Waste water related & Parasites maturing in waste water & Ascaris lumbricoides, Cyclospora cayetanensis \\
\hline \multirow{2}{*}{$\begin{array}{l}\text { Diseases related to } \\
\text { damp }\end{array}$} & Toxicosis related to food stored damp & Mycotoxins (aflatoxin, patulin, ochratoxin) \\
\hline & Disease related to living in damp conditions & Mycotoxins \\
\hline
\end{tabular}

One of the major pathways through which contaminated water affects individuals is though drinking water. In terms of management, these supplies range from unimproved sources where the individual is effectively consuming raw water, to large, managed supplies where multiple barriers exist to prevent microbiological contamination of water supplies. Climate change has a number of potential influences upon water treatment, and higher temperatures are known to enhance biological methods of water treatment [43]. However, countering this effect are a number of other factors linked to more extreme weather, such as increased rainfall and water turbidity $[44,45]$ which may increase risks to microbiological water quality in some locations. A review of the impacts of climate change on surface water contamination concluded that it was likely to increase the risk associated with drinking 
water supplied mainly during extreme climatic events [46]. Pathogen risk was argued to rise mainly due to elevated temperatures and extreme rainfall, especially in temperate countries.

Ensuring appropriate water infrastructure, regular monitoring and appropriate management techniques, such as Water Safety Plans, are likely to be increasingly important to address changing risks. In the future rapid testing (e.g., PCR based) [47] and new treatment technologies (e.g., nanomaterials) [48] may play an increasing role in addressing climate change challenges. The ability to respond to changing risks will vary according to the resources available. In terms of supplies less able to adapt to a changing water quality, we highlight small water supplies, private water supplies as well as supplies in lower income areas as potentially being at greatest risk.

\section{Settings Other Than Drinking Water, and the Range of Water-Related Diseases}

Drinking water is not the only route through which potentially contaminated water may affect individuals; bathing water is another important pathway. As argued above, modelling is challenging, and this is especially the case given the multiple number of potential exposure points. Water quality modelling is currently possible, and could be extended to include climate change. Warning the public about water risks in relation to bathing water is one way to address changing risks associated with climate change [49].

Infections can be related to exposure to natural and man-made recreational waters. These include thermal waters (amoebae, Legionella) [50], inland recreational fresh waters, ponds and lakes (cyanobacteria, Pseudomonas aeruginosa [51], enteric pathogens, Leptospira spp., Trichobilharzia spp. [52], Schistosoma spp. [53], Vibrio spp.) [54], wild swimming (enteric pathogens), coastal waters including sea sports, sea water pools, bathing beaches (dinoflagellates and diatoms, jelly-fish larvae, toxic seaweed, enteric pathogens) and the beach environment, including run-off from fields and sewers, beach sand, and so forth. Recreational exposure to man-made fresh water pools includes treated swimming pools (Cryptosporidium), natural pools (enteric pathogens), spa baths (P. aeruginosa [55], Legionella spp.), water parks (Cryptosporidium spp.), foot wash and foot spas (Mycobacterium spp. [56] and P. aeruginosa [57]) and inflatables (P. aeruginosa, Aeromonas hydrophila [58]).

Infections from working in water can include Schistosoma spp., Burkholderia pseudomallei [59] and wound infections from water (Vibrio vulnificus [60], Mycobacterium spp., [61] B. pseudomallei [62]). Water transmission in man-made systems and equipment includes hospital/medical uses of water, water for dialysis and hydration (cyanobacteria), water for washing and decontamination, hospital water systems, water transmission in intensive care (P. aeruginosa) [63-66], contaminated equipment including endoscope washers (Mycobacterium spp.) [67], humidifiers, taps and wash basins, showers (Legionella spp.) and water births [68-71]. A variety of industrial waters can contribute to respiratory infection, including cooling towers and thermally polluted waters (Legionella spp.).

The disposal of waste can contribute to water contamination, particularly chemical contamination, but also pathogens. Sewage disposal is the main source of human faecal contamination in developed countries and sewage treatment is designed to reduce this to a minimum. However, animal waste probably represents a larger input to the natural environment as a result of defecation on fields and run-off. In developing countries, human faeces are commonly deposited in the natural environment at defaecation sites or middens where the 'night soil' matures over time and some pathogens require this to become infectious (Ascaris lumbricoides [72], Cyclospora cayetanensis). There are also potential risks associated with water passing through waste burial sites, particularly mass graves associated with plague, smallpox or anthrax, and from water running from leather processing sites (Bacillus anthracis).

Water is important in agriculture and food production, and irrigation may be conducted with water that is not of potable quality. Where this is done for salad items and soft fruit that are eaten without further treatment, then outbreaks can occur [73,74]. Contaminated water used for washing and food processing can also cause outbreaks. Food retailers require water on the premises in order for staff to wash their hands. Water-related foodborne disease (water-based) includes helminths and other macro-parasites, ciguatera, shellfish dinoflagellate toxins and similar toxins [75]. As shellfish 
filter large volumes of water, there are common outbreaks associated with faecal pathogens (especially norovirus and Vibrio cholerae [76], Vibrio parahaemolyticus [76] and Vibrio vulnificus [76]). Many processed drinks and foods contain water, and infections are prevented by source water protection, filtration, heat treatment or preservative treatment and a matrix that prevents pathogenic organisms from multiplying.

Where water is in short supply, water washed diseases may occur [14]. This can be in desert areas where lack of water and chronic water shortages, together with flies resulting from poor waste disposal, can allow the transmission of enteric (shigellosis) and eye infections (Chlamydia trachomatis).

Vector borne diseases (mosquito-borne, tick-borne, fly-borne, triatomid bug) can be strongly influenced by weather and geographic parameters, are likely to change in distribution as a result of climate change and are difficult to predict accurately [77], but are not examined further in this paper.

\section{Methods and Reviews Related to Water Quality and Health}

Systematic review (SR) and meta-analysis (MA) are methods which have been used extensively to elucidate the relationships between microbiological contamination and ill health. As climate change will impact water contamination, an examination of systematic reviews relating to water quality has been undertaken. A SR of the effectiveness of interventions to reduce the health impact of climate change around the world, found a weak evidence base and gaps in dealing with extreme weather events [78]. This follows a previous SR [79]. The seasonal differences in faecal contamination of source waters used for supplying drinking water have been examined in a SR [80]. They found increased contamination in the wet season. A general review of wider evidence for pathogens being waterborne and the impacts of climate are included in the review of pathogens (Table A1, Appendix A).

\section{Flooding}

Flooding causes local or widespread disruption of normal life and makes waste disposal difficult. A SR of waterborne infections and climate change found evidence of outbreaks and increased sporadic disease following flooding [37], and included cholera and other diarrhoeal diseases. Other reviews have found similar results [36] and the health impacts of flooding showed that monitoring, mitigation and communication had the potential to reduce loss of life [81]. Tsunami related flooding can have a disproportionate impact on women, children and the elderly [82]. The impact of flooding is generally greater in developing rural countries with poor infrastructure compared to developed countries where people in flooded properties can be readily moved to non-flooded areas for a temporary period and provided with potable water. This is particularly true of coastal areas [83]. After Hurricane Katrina, there was an outbreak of norovirus deriving from populations being held in a stadium [84] and an increase in Vibrio infections resulting from coastal waters [85]. An increase in flood related disease might be expected under climate change with altered weather patterns and more severe weather events. Early warning systems with effective disease surveillance, prevention and response are important in preventing infectious diseases following flooding [86].

\section{Drought}

Drought can be a hidden risk with the potential to cause a public health disaster [87]. A SR of the health effects of drought found the main categories included: Nutrition-related effects; water-related disease (including Escherichia coli, cholera and algal bloom); airborne and dust-related disease (including coccidioidomycosis); vector borne disease (including malaria, dengue and West Nile Virus); mental health effects; and other health effects [88]. A review in Canada found that drought can affect respiratory and mental health, with illnesses related to exposure to toxins, food, water and vector-borne diseases [89]. Drought-related health impacts vary widely and depend upon drought severity, population vulnerability, health and sanitation infrastructure, and available resources with which to mitigate impacts as they occur. Population resilience is affected by socio-economic environment. A SR has examined the likely impacts of climate change on water quality and disease in the Mekong delta basin [90]. 


\section{Disasters}

The water needs for disaster recovery identified relations between the amount of water provided and the diarrhoea and mortality rates, but emphasised the inadequacy of the data [91]. As responses to climate related emergencies influence subsequent morbidity and mortality, it is important to understand the impact of water, sanitation and hygiene (WASH) interventions on health outcomes in humanitarian crises. The current evidence base is limited, and is unsuitable for determining associative or causal relationships [92]. People living with HIV have a higher morbidity where there is contaminated water, poor hygiene and sanitation. Programs to improve these also improved morbidity [93].

\section{Climate Impacts on Water, Sanitation and Hygiene (WASH)}

Understanding the climate change impacts on water-related diseases requires an understanding of water, sanitation and hygiene. Much of the burden of waterborne disease appears to result from small and rural supplies, although there may be under-ascertainment of outbreaks in urban areas with mains supplies due to limited disease surveillance. This is important in an examination of the burden of waterborne disease and future changes as a result of altered weather patterns. Waterborne disease burden methodologies used in developed countries to attribute acute gastrointestinal infection (AGI) to drinking water, include simple point estimates, quantitative microbial risk assessment, Monte Carlo simulations based on assumptions and epidemiological data from the literature [94]. In developing countries, inadequate water and sanitation are associated with risk of diarrhoeal disease [95], particularly in young children, and raised maternal mortality occurs in households with poor sanitation and a poor water environment [96]. The microbiological quality of household water correlates with health outcomes (diarrhoea and trachoma) [97], although improved sources do not always provide water that is completely free of faecal contamination. Point of use devices can be effective [98], however, contamination of water between source and point of use remains a continuing problem [99]. An examination of interventions to reduce diarrhoea in less developed countries found, that while interventions were generally effective, the heterogeneity between studies made the exact conditions causing disease reductions difficult to assess [100], and others found a dearth of methodologically sound studies [101]. There were also inadequacies in behavioural models and frameworks for intervening in WASH specific interventions [102]. The impacts of WASH on child diarrhoeal morbidity has been examined in a number of studies [103] and there was a general lack of good quality studies of diarrhoea morbidity in children in India [104]. While water treatment (e.g., chlorine water treatment at point of use) can be effective, most studies are short term [105]. An examination of water distribution system deficiencies demonstrated that study blinding can be important [106]. Expecting to obtain good information on the risks from water-related infections under climate change, in the absence of reliable, experimental evidence for effectiveness of interventions, seems naïve.

Of 293 outbreaks linked to water supplies in Canada and the US, failure of existing treatment and lack of water treatment were the leading causes [107]. Temporary water outages and chronic outages in intermittently operated systems can be associated with gastrointestinal infection [106]. The Walkerton outbreak of E. coli O157 and Campylobacter in Canada highlighted the role that heavy rainfall can play in outbreaks [108,109]. However, this was also linked to poor management. There are many studies that have examined the role of rainfall before an outbreak. It is generally seen that heavy rain is more common before many outbreaks, suggesting the source water is compromised [32,36,110-112]. The association between waterborne outbreaks with a period of prolonged low rainfall in the four weeks before an outbreak may also indicate a vulnerability to weather [32], although this was not seen in other studies. There is a strong need for water utilities to build water safety plans that factor in likely changes in climate over future scenarios, while retaining an understanding of historical weather events. Behaviour change interventions for water and sanitation in developing countries have looked at risk factors, attitudinal factors, normative factors, ability factors, and self-regulation factors [113]. 
Social marketing for water and sanitation products showed this improves health threat awareness and provides a solution to reducing disease burden [114]. Good water sourcing, treatment, distribution, storage and clean point of use remain the key to community health. Water and sanitation in schools is an important area where improvements can facilitate improved educational achievement [115].

There is a need for robust epidemiological studies that quantify the health risks associated with both small, private water systems, and large community supplies. More information is needed on pathogen quantification, susceptibility of vulnerable sub-populations, the influence of extreme weather events, the proportions of the population served by different water sources and the treatment level, source water quality and condition of the distribution system infrastructure. The exposure to faecal contamination in potable water has been estimated, suggesting that there may be a substantial under-estimate of disease burden [116].

\section{Which Water-Related Pathogens Are Important?}

A wide range of pathogens are known to be transmitted through water (Table A1, Appendix A). Historically, some diseases, such as cholera, dysentery and typhoid have been very important from a public health perspective, causing extensive morbidity and mortality. Many of the diseases are a problem where there is limited infrastructure, as in developing countries or rural regions of developed countries and can be sensitive to social disruption and infrastructure damage. It is important to understand the future health impacts of climate change and to understand where the most important disease burdens will be. Waterborne diseases can be sensitive to emergence, but this is generally related to the discovery of new infectious agents or identification methods (e.g., cryptosporidiosis, microsporidiosis, legionellosis, hepatitis E) rather than newly emergent diseases. However, some classical waterborne pathogens may emerge in new areas with climate change (e.g., cholera), and Legionnaires' disease, which is predominately derived from contaminated water systems in the built environment, may increase as a result of raised temperatures.

An examination of 24 analytical studies assessing the association between extreme precipitation or temperature and drinking water-related waterborne infections, found that most studies showed a positive association with increased precipitation or temperature. A few studies showed an association with decreased precipitation and several in which there was no association [117]. Infections included cholera, typhoid, paratyphoid, campylobacter, shigella, hepatitis A, cryptosporidiosis, giardiasis and waterborne outbreaks.

\subsection{Schistosomiasis}

Schistosoma are transmitted as a result of cercaria burrowing through the skin of people working or bathing in contaminated waters. The cercaria develop in infected snails. Although temperature, precipitation and humidity are known to influence the development of schistosome parasites, as well as their intermediate snail hosts (Biomphalaria spp.; Oncomelania spp.) [118-121] and their internal defence system [122], modelling climate change impacts on disease can have mixed results [123,124]. Some scenarios show predicted increases and decreases [125], with degrees of uncertainty [126,127]. Increases in parasite growth related to temperature can be offset by increased snail mortality at higher temperatures [127]. Schistosoma eradication campaigns may be impacted by changes in snail distribution, migrant workers and weather [128]. The impact of water and sanitation on schistosomiasis has shown that access to safe water and adequate sanitation is important in reducing schistosomiasis $[129,130]$.

\subsection{Guinea Worm}

Dracunculus medinensis is transmitted by drinking water contaminated with copepods that contain the parasite larvae, and infections are easily controlled with simple measures. This disease is moving rapidly towards eradication under the supervision of the Carter Centre, with the World Health Organisation, UNICEF and CDC [131,132]. Although climate is likely to influence disease, the biggest 
problems in elimination have been organising surveillance in conflict areas [133], and the recent demonstration of a transmission cycle in dogs, particularly in Chad [134].

\subsection{Nematodes}

Ascaris, Trichuris and hookworms are soil transmitted nematodes, and transmission is related to inadequate methods for faecal/wastewater disposal. Risk of Necator infections were linked to rainfall in East Timor [135]. For Ascaris lumbricoides, higher temperatures in the coolest quarter of the year resulted in reduced risk. There is little evidence to suggest that changes in climate might greatly increase disease transmission and evidence that helminth control measures, if effectively undertaken, might cause substantial reductions in disease. A SR of spatial and temporal distribution of soil transmitted helminths was used to determine changing disease burden and predict treatment needs for eradication [136]. Another soil helminth SR and MA identified reductions in disease associated with WASH activities, but emphasised the limited nature of the studies, which were mostly observational [137].

\subsection{Protozoa}

Waterborne cryptosporidiosis is common, even in developed countries because the parasite's oocysts are resistant to chlorine, which is the main chemical treatment used for disinfecting both drinking water and indoor recreational waters, including swimming pools [138]. The oocysts are common in natural waters and can be present in source waters. A SR and MA of the impacts of weather on surface waters indicated that contamination with Cryptosporidium and Giardia was 2.61 and 2.87 higher during and after heavy rainfall [139]. A SR was used to examine the risks of endemic cryptosporidiosis, and found increased risk associated with the unsafe use of water [140]. This makes the need for risk assessment necessary. Cryptosporidiosis outbreaks may well increase if there are more frequent incidents of severe weather. In many countries, surveillance involving the laboratory identification of isolates is absent or suboptimal. Without good surveillance, outbreaks will be missed, and the prevention of these not dealt with. A SR of Toxoplasma outbreaks showed longer incubation following exposure to contaminated water compared to meat related exposures [141]. A SR of intestinal protozoal infections found significantly lower odds of infection in people with treated water [142]. Giardia transmission is not as well understood as Cryptosporidium, mostly because typing approaches have been suboptimal and routine surveillance in developed countries has focussed on the link to travel, rather than indigenous sources of infection [143]. Hygiene linked to water is important and occurrence in developing countries shows no relationship to rainfall [144]. However, the infection is common, and determining any change due to climate may be difficult. Both Giardia and Cryptosporidium are common in developing countries, and include a variety of species and types, and it has been suggested that climate change will increase malnutrition and contamination of water sources [145].

Naegleria fowleri infections are commonly associated with thermally polluted waters and cases might increase with raised temperatures. However, many of the reported infections are associated with geothermal waters that will not be greatly impacted by climate change.

\subsection{Cholera and Other Diarrhoeal Diseases}

Cholera remains one of the major diarrhoeal disease concerns with climate change. There has been a long history of associations between seasonality and weather as contributing factors in outbreaks. Cholera is also readily inserted into disaster situations and can contribute to morbidity and mortality. Examination of the weather relationship in El Niño years to the occurrence of cholera suggests that weather might be able to be used for predicting outbreaks in East Africa [146]. However, the assumptions in models are not necessarily always proven in practice [147-149]. As pandemics of cholera have occurred in the past, there is a strong need to reduce the risks of another pandemic arising out of a disaster situation. Changes in seawater temperature may contribute to changes in disease incidence [150]. The impact of water, sanitation and hygiene interventions are important in the 
control of cholera [151]. Home water treatment and storage interventions can reduce diarrhoea and cholera [152]. This study demonstrated the dearth of good evidence. A SR looked at the environmental determinants of cholera in inland Africa [147]. They found that spread was linked to displaced populations and the poor water and sanitation associated with these settings. A similar review of coastal cholera by the same authors found that cholera seasonality is driven by rainfall-induced contamination of unprotected water sources [148].

The impact of a changing climate is most important when it comes to the quality of drinking water and diarrhoeal diseases, particularly in developing countries [37]. There are relationships between many of the bacterial infections and temperature, and evidence of links to heavy rainfall and flooding [32,110,117]. The sources of exposure may be agricultural [153] or from sewage, and the different sources contain different pathogens, with human viruses rarely being detected in animal waste [154]. Engagement with the water sector is important in reducing risks.

\subsection{Legionella}

Legionnaires' disease is commonly associated with thermally polluted waters [155]. Due to the relationship between temperature and the occurrence of Legionella spp. in water, one might expect an increase in cases or outbreaks associated with climate change. Studies indicate that temperature and humidity [156,157], or vapour pressure [158], may play a role in the occurrence of sporadic disease. Due to concerns about the multiplication of Legionella spp. at the consumer endpoint (taps and showers) the European Drinking Water Directive has been modified to include a risk assessment for this pathogen. A SR on cooling towers related to Legionnaires' disease provided quite detailed advice on risks and their mitigation [159]. As climate changes becomes more apparent, there may be improvements in our understanding of previously unrecognised transmission routes from the natural environment.

\subsection{Leptospira spp.}

Leptospirosis outbreaks are commonly linked to flooding in rural developing countries. This relates to the dislocation of small mammal populations [160-162]. It is expected that an increase in flooding will contribute to more leptospirosis cases. Floods are one of the most important drivers of leptospirosis on islands and in Asia [163].

\subsection{Pseudomonas aeruginosa}

The ability of Pseudomonas to grow in water is dependent on being able to extract nutrients from the surfaces it is growing on, and to bloom within the body of the water. This includes outbreaks of folliculitis associated with spa pools and is dependent on temperature. One must therefore expect some increase associated with increased temperatures. A SR of Pseudomonas aeruginosa in hospitals found evidence that the water systems can be the source of this organism, and that contamination mostly occurs at the distal end [164]. Water resource management is important in control of this [165]. P. aeruginosa infections are common, and numbers related to water use may increase with a changing climate.

\subsection{Harmful Algal Blooms (HABs)}

Harmful algal blooms have the potential to increase with changes in climate [75]. The neurotoxin producing dinoflagellate and diatom plankton mainly cause disease through shellfish poisoning and Ciguatera poisoning in fish, but can also be responsible for the mass deaths of fish. Monitoring of shellfish waters can facilitate shellfish bed closures as a means of controlling exposure through food, while ciguatera is mostly controlled by not eating carnivorous reef fish. Blooms can cause respiratory symptoms in people on affected bathing beaches. Freshwater cyanobacteria are a potential risk through untreated potable water, and the toxic products can cause liver disease. In developed countries, these problems should be dealt with by water utilities. 


\subsection{Shiga-Toxin Producing E. coli (STEC)}

As water is commonly contaminated with the faeces of agricultural animals, ways of reducing E. coli $\mathrm{O} 157$ excretion by cattle have been examined [166]. Further work on preventing haemolytic uremic syndrome found that vaccine use on animals reduced carriage, but the study emphasised the importance of public health measures [167]. Patients were consistently found to have exposure to rodents, behavioural and sanitation related risk factors.

\subsection{Norovirus}

An examination of norovirus transmission routes showed higher attack rates in foodborne than waterborne transmission, and higher rates in surface derived than groundwater derived waters [168]. Given the very common occurrence of this pathogen, any change will possibly depend more on progress in vaccinations rather than an impact from climate change. However, outbreaks may occur when large populations are kept in confined areas during an emergency [84].

\subsection{Trachoma}

Chlamydia trachomatis is the cause of trachoma, a disease of the eyes related to water shortage. Water can be important in reducing trachoma, where the F and E of the SAFE strategy (surgery, antibiotics, facial cleanliness and environmental improvement) were strongly linked to disease reduction [169]. Another trachoma SR found the studies too limited to demonstrate the impact of $\mathrm{F}$ and $\mathrm{E}$ [170]. The SAFE interventions are dramatically reducing disease but could be disrupted in chaotic situations associated with climate change.

\section{Preparing for Climate Change}

The principal reason for drinking water infections is the absence of reliable infrastructure. For rural communities worldwide, this includes the source waters used for drinking, the methods used to transport it from source to household, safe storage within the household, any treatment used and hygiene and sewage disposal changes. The principal underlying factor is poverty. Improving water treatment needs to be accompanied by improvements in sewage disposal and hygiene training. Climate change will not alter these underlying principles. What could change is the frequency of water shortages, population movements, conflict, refugee camps and so on, and a deterioration in the hygienic quality of water that people receive. Good planning associated with disasters can reduce the risks of waterborne diseases [41]. Any increase in disease associated with disasters in developing countries can have knock-on effects in developed ones.

With climate change, it is important to build knowledge of the mechanisms by which changes in weather can influence individual pathogens, and how these may subsequently affect human health. Not all problems associated with diarrhoeal diseases are as a result of outbreaks and it is important to understand the drivers for sporadic disease, and the disease burdens associated with the range of common pathogens. Good surveillance is necessary in order to detect clusters and outbreaks at an early stage, so that they can be investigated and controlled in a timely way, and so that future outbreaks can be prevented.

Most enteric pathogens are very seasonal, with bacterial pathogens (e.g., Salmonella spp., Campylobacter spp., STEC) predominating in the summer months, while viral gastroenteritis predominantly peaks in the winter (e.g., norovirus, rotavirus) [171]. The analytical examination of weather drivers has relied on time series approaches, that have limitations due to the collinearity between, for example temperature and seasonality, making it difficult to get definitive evidence of the causal mechanisms and to predict the impact of changes in climate. A review of mathematical approaches to demonstrating weather influences on waterborne infections has been undertaken [172]. The studies grouped into two clusters: Process-based models (PBM) and time series and spatial epidemiology (TS-SE). A review of analytical epidemiology studies looked at the quality of evidence 
for associations with rainfall, temperature, and so on, and waterborne disease identified the difficulties with developing optimum approaches [117]. A more systematic examination of the seasonality of a full range of pathogens [171] may widen our understanding of those that are linked to climate fluctuations. There are also a range of less analytical approaches that can contribute to a better understanding of waterborne pathogens and future risks (Table A1, Appendix A). Further development of tools to separate the effects of weather from other influences on seasonality needs to be undertaken, utilising surveillance data from a wider geographic area and linking local cases to local weather.

\section{Conclusions}

There have been a number of previous reviews and publications highlighting potential impacts of climate change and water-related illness in water-related or waterborne disease [37,38,117,172-182]. Some approaches examine the technological means to best represent the data $[42,175,177,178,183]$, some examine outbreaks [28,32] and others focus on effects of the hydrological cycle in particular regions [28,110,174,179], while others have adopted a systematic review approach [37]. This paper has examined a full range of water-related pathogens, providing an evidence base for regarding them as water-related and indicating which studies have provided evidence. In addition to a changing climate, the world will continue to experience an increasing human population, with ever greater inter-connectivity through travel and information technology. Animal infections will continue to contribute to zoonotic disease and we should expect new pathogens to continue to arise. With climate change we need to watch for the rise in cholera worldwide. Although this is predominantly a disease of the poor and is not generally a problem in developed countries that have safe drinking water, it still has the potential to cause pandemic disease if there is general chaos, as can be found in disaster situations. The growth of Vibrio cholera in coastal waters means there can be changes in exposure with alterations in rainfall and temperature [150]. There remains a strong need for timely surveillance and rapid epidemiological response to outbreaks and new waterborne pathogens. The needs of developing countries in relation to waterborne diseases are both technical and financial, and ensuring adequate quantities of good quality water will be essential in preventing excess morbidity and mortality in areas that will suffer from substantial changes in climate in the future.

Author Contributions: G.N. initiated the paper and reviewed the evidence for waterborne disease and climate change. C.H. provided the climate change overview and I.L. the interface between waterborne diseases and climate change. All three contributed to the manuscript production and producing a final text.

Acknowledgments: The research was funded in part by the National Institute for Health Research Health Protection Research Unit (NIHR HPRU) in Environmental Change and Health at the London School of Hygiene and Tropical Medicine in partnership with Public Health England (PHE), and in collaboration with the University of Exeter, University College London, and the Met Office; the UK Medical Research Council (MRC) and UK Natural Environment Research Council (NERC) for the MEDMI Project (https://www.data-mashup.org.uk). Some of the work was conducted while seconded from HPA/PHE to the European Centre for Disease Prevention and Control (ECDC). The views expressed are those of the authors not necessarily those of the NHS, the NIHR, the Department of Health and Social Care or Public Health England. IL is part funded by the National Institute for Health Research Health Protection Research Unit (NIHR HPRU) in Gastrointestinal Infections at University of Liverpool in partnership with Public Health England (PHE), in collaboration with University of East Anglia, University of Oxford and the Institute of Food Research.

Conflicts of Interest: The authors declare no conflicts of interest in respect of this work.

\section{Abbreviations}

$\begin{array}{ll}\text { CA } & \text { Cost analysis } \\ \text { CEO } & \text { Circumstantial evidence only } \\ \text { CSS } & \text { Cross sectional survey } \\ \text { EACI } & \text { Ecological association between climate and infections } \\ \text { EACO } & \text { Ecological association between climate and outbreaks } \\ \text { EACWQ } & \text { Ecological association between climate and water quality } \\ \text { FTA } & \text { Fault Tree Analysis } \\ \text { GAMTS } & \text { Generalised additive model time series }\end{array}$


GDSE

GLM

HSM

LR

MLM

MM

MMF

MMO

MMST

NBM

MSRA

NE

OI

PMCC

POCS

PORA

POTA

POWE

PRA

RAI

RCS

RCCS

RILO

ROS

RRM

RSA

RSE

SA

SCS

SFA

TSAT

QMRA

WMCS

WMR

Gastrointestinal and dermatological symptoms and exposure

Generalised linear model

Hindsight suitability model

Literature review

Multi-level modelling

Mathematical modelling

Microbiological monitoring of flooding

Microbiological monitoring of outbreaks

Microbiological monitoring with salinity and temperature

Negative binomial model

Multiple stepwise regression analysis

No published evidence

Outbreak investigation

pairwise-matched case-control study

Prospective observational cohort study

Post outbreak rainfall analysis

Post outbreak temperature analysis

Post outbreak water examination

Poisson regression analysis

Review of animal infections

Retrospective cohort study

Retrospective case-crossover study

Rodent investigation linked to outbreak

Retrospective outbreak surveillance

Rainfall runoff model

Rainy season association

Recreational swimming exposure

Spatial analysis

Sporadic case series

Seasonal factor analysis

Time series analysis of temperature

Quantitative microbial risk assessment

Water microbiology and case series

Water microbiology and rainfall 


\section{Appendix A}

Table A1. Evidence of water related, waterborne, water-based, water contamination of equipment, water washed, water-based food contamination, water toxicosis, respiratory aerosol transmitted organisms, those that might be subject to climate change and the types of evidence.

\begin{tabular}{|c|c|c|c|c|c|}
\hline Pathogen & How Climate Might Affect Disease Occurrence & $\begin{array}{l}\text { Strength of } \\
\text { Evidence for } \\
\text { Water Related } \\
\text { Infections }\end{array}$ & $\begin{array}{l}\text { Human } \\
\text { Waterborne } \\
\text { Outbreaks or } \\
\text { Infections }\end{array}$ & $\begin{array}{l}\text { Type of } \\
\text { Infection } \\
\text { Route }\end{array}$ & $\begin{array}{l}\text { Study Linking } \\
\text { Weather/Climate } \\
\text { and Infection }\end{array}$ \\
\hline Acanthamoeba & $\begin{array}{l}\text { A. polyphaga linked to contact lens washing and hygiene important. Infections linked to } \\
\text { flooding (presumed contamination of potable water). Water contamination links. }\end{array}$ & Strong & [183-194] & Waterborne & $\begin{array}{l}\text { PMCC [195]; LR } \\
{[196]}\end{array}$ \\
\hline Adenovirus & $\begin{array}{l}\text { Subgroups A-E cause upper respiratory infections, conjunctivitis, febrile illness, sore throat } \\
\text { and swollen glands. The enteric subgroup F adenoviruses Ad } 40 \text { and Ad } 41 \text { cause } \\
\text { gastroenteritis in children. Contamination of groundwater used as a drinking water source } \\
\text { and from faecal or respiratory contamination of untreated recreational waters. Swimming } \\
\text { pool outbreaks. }\end{array}$ & Moderate & {$[184,197-201]$} & Waterborne & $\begin{array}{l}\text { POWE [202]; OI } \\
{[203]}\end{array}$ \\
\hline Aeromonas spp. & $\begin{array}{l}\text { Can cause wound infections and are thought to be a cause of diarrhoea. Point source } \\
\text { diarrhoea outbreaks do not occur and evidence of their role in diarrhoeal disease is equivocal. } \\
\text { They are commonly found in raw foods, sewage and source waters, and can bloom in } \\
\text { drinking water distribution systems. Seasonality similar to Salmonella. }\end{array}$ & Weak & $\begin{array}{l}\text { No waterborne } \\
\text { outbreaks } \\
\text { [204]. }\end{array}$ & Waterborne & $\mathrm{NE}$ \\
\hline Arcobacter spp. & $\begin{array}{l}\text { A. butzleri is a Campylobacter-like bacteria that is associated with watery diarrhoea. A. } \\
\text { skirrowii can cause persistent diarrhoea. A. cryaerophilus is a third species found in human } \\
\text { infections. Arcobacter spp. can be isolated from animals, birds, food, water and the } \\
\text { environment. Arcobacter infections are uncommon and there is no evidence of the impact of } \\
\text { weather on infections. Three waterborne outbreaks but no evidence Arcobacter was the } \\
\text { cause. }\end{array}$ & Weak & {$[202,205]$} & Waterborne & $\mathrm{NE}$ \\
\hline Ascaris & $\begin{array}{l}\text { A. lumbricoides ova in 'night soil' need to mature at ambient temperatures before they are } \\
\text { infectious. Rain can wash infectious oocysts into water sources used for irrigating salad } \\
\text { vegetables. Transmission through irrigation of salad vegetables. }\end{array}$ & Weak & {$[206-208]$} & Water based & $\mathrm{NE}$ \\
\hline Astrovirus & $\begin{array}{l}\text { Astroviruses cause diarrhoea in children under five years old. Viruses are excreted in faeces, } \\
\text { and they will be present in sewage. Contact with contaminated recreational waters may be a } \\
\text { risk factor. Outbreaks often mixed. Outbreak linked to flood water contamination of shellfish } \\
\text { with several viruses. }\end{array}$ & Weak & {$[31,209-212]$} & Waterborne & POWE [213] \\
\hline $\begin{array}{l}\text { Burkholderia } \\
\text { pseudomallei }\end{array}$ & $\begin{array}{l}\text { Waterborne outbreaks in Australia with circumstantial \& epidemiological evidence for water } \\
\text { as the source. Infections and outbreaks linked to tropical storms, rainfall and drought. }\end{array}$ & Strong & [214-224] & Waterborne & POWE $[216,222]$ \\
\hline Burkholderia cepacia & $\begin{array}{l}\text { Contamination of indoor water systems, predominantly in hospitals; contaminated sterile } \\
\text { solutions, [225-229] disinfectant solution and taps can occur. Clinical circumstantial \& } \\
\text { epidemiological evidence but no link to weather parameters. }\end{array}$ & Strong & $\begin{array}{l}{[225,227,230-} \\
245]\end{array}$ & Waterborne & $\mathrm{NE}$ \\
\hline
\end{tabular}


Table A1. Cont.

\begin{tabular}{|c|c|c|c|c|c|}
\hline Pathogen & How Climate Might Affect Disease Occurrence & $\begin{array}{l}\text { Strength of } \\
\text { Evidence for } \\
\text { Water Related } \\
\text { Infections }\end{array}$ & $\begin{array}{l}\text { Human } \\
\text { Waterborne } \\
\text { Outbreaks or } \\
\text { Infections }\end{array}$ & $\begin{array}{l}\text { Type of } \\
\text { Infection } \\
\text { Route }\end{array}$ & $\begin{array}{l}\text { Study Linking } \\
\text { Weather/Climate } \\
\text { and Infection }\end{array}$ \\
\hline $\begin{array}{l}\text { Balamuthia } \\
\text { mandrillaris }\end{array}$ & $\begin{array}{l}\text { Occurs in soil and causes amoebic meningoencephalitis. Limited evidence of occurrence in } \\
\text { thermal water sources and hot water systems [246-248]. }\end{array}$ & Weak & {$[185,246,249]$} & Waterborne & $\mathrm{NE}$ \\
\hline Balantidium coli & $\begin{array}{l}\text { A ciliated protozoan organism found in wild and domestic pigs. It causes dysentery in man } \\
\text { and other primates. The routes of transmission are not clear. Rare infection thought to be } \\
\text { drinking water-borne but little supporting evidence. }\end{array}$ & Weak & {$[187,250-252]$} & Waterborne & $\mathrm{NE}$ \\
\hline Blastocystis hominis & $\begin{array}{l}\text { An amoeba that can be detected in patients with diarrhoea. Limited evidence of family } \\
\text { outbreak [253] but no waterborne outbreaks. Its significance as a human pathogen is unclear } \\
\text { [254-256]. Transmission is probably by contaminated food and water. Little evidence of } \\
\text { waterborne transmission. No weather links. }\end{array}$ & Weak & $\begin{array}{l}{[187,190,257-} \\
259]\end{array}$ & Waterborne & $\mathrm{NE}$ \\
\hline Bocavirus & $\begin{array}{l}\text { Human bocavirus (HBoV) is comparatively newly discovered and is thought to be spread } \\
\text { from person to person by the respiratory and faecal-oral routes. The virus has been detected } \\
\text { in respiratory samples, faeces and blood. It has been commonly detected in children with } \\
\text { upper or lower respiratory infections. Infection has been seen worldwide. No evidence of } \\
\text { waterborne infection or infections linked to water, although it has been detected in sewage } \\
\text { [260]. }\end{array}$ & None & None & Unknown & $\mathrm{NE}$ \\
\hline Campylobacter spp. & $\begin{array}{l}\text { The commonest bacterial cause of diarrhoea. Most infections are sporadic, but waterborne } \\
\text { outbreaks linked to camp sites, travelling abroad, hospitals and large communities. Infection } \\
\text { is commonly derived from contaminated poultry and water for the chicken flocks may be } \\
\text { one source of contamination. Campylobacter spp. are spiral/curved organisms when isolated } \\
\text { from patients, and change to a more resistant coccal stage when present in water. Most } \\
\text { human infections are caused by C. jejuni, C. coli and C. lari. Campylobacter fetus subsp. fetus, } \\
\text { can cause human infections, with septicaemia and gall bladder infection being more common } \\
\text { than with the other species. C. upsaliensis, C. hyointestinalis subsp. lawsonii and C. } \\
\text { hyointestinalis subsp. hyointestinalis are occasionally isolated from diarrhoeal patients. } \\
\text { Infection through contaminated drinking water-heavy rainfall }\end{array}$ & $\begin{array}{l}\text { Strong, } \\
\text { outbreaks } \\
\text { represent a small } \\
\text { percentage of } \\
\text { cases }\end{array}$ & [261-268] & Waterborne & $\begin{array}{l}\text { PORA }[109,269] \\
\text { EACI }[270]\end{array}$ \\
\hline Chilomastix mesnili & $\begin{array}{l}\text { A flagellated protozoan that is thought to have limited pathogenicity. Parasite present in } \\
\text { wastewater. It is probably transmitted by contaminated food and water, and can be found in } \\
\text { patients with diarrhoea. Weak circumstantial evidence of water transmission [271-274]. No } \\
\text { link to climate. }\end{array}$ & Weak & $\mathrm{NE}$ & Unknown & $\mathrm{NE}$ \\
\hline $\begin{array}{l}\text { Chlamydia } \\
\text { trachomatis }\end{array}$ & $\begin{array}{l}\text { Trachoma, caused by } C \text {. trachomatis, is associated with a lack of water. Transmission by flies is } \\
\text { reduced by face washing. }\end{array}$ & Strong & $\mathrm{NE}$ & $\begin{array}{l}\text { Water } \\
\text { washed }\end{array}$ & $\mathrm{NE}$ \\
\hline $\begin{array}{l}\text { Chryseobacterium/ } \\
\text { Elizabethkingial } \\
\text { Flavobacterium }\end{array}$ & $\begin{array}{l}\text { E. meningoseptica, (syn. C. meningoseptica, F. meningoseptica). Contamination of washed } \\
\text { wounds. Water aerator colonisation and ICU infection—no identified climate association. }\end{array}$ & $\begin{array}{l}\text { Weak, } \\
\text { circumstantial }\end{array}$ & {$[275-277]$} & Waterborne & $\mathrm{NE}$ \\
\hline
\end{tabular}


Table A1. Cont.

\begin{tabular}{|c|c|c|c|c|c|}
\hline Pathogen & How Climate Might Affect Disease Occurrence & $\begin{array}{l}\text { Strength of } \\
\text { Evidence for } \\
\text { Water Related } \\
\text { Infections }\end{array}$ & $\begin{array}{l}\text { Human } \\
\text { Waterborne } \\
\text { Outbreaks or } \\
\text { Infections }\end{array}$ & $\begin{array}{l}\text { Type of } \\
\text { Infection } \\
\text { Route }\end{array}$ & $\begin{array}{l}\text { Study Linking } \\
\text { Weather/Climate } \\
\text { and Infection }\end{array}$ \\
\hline $\begin{array}{l}\text { Coronavirus } \\
\text { (SARS) }\end{array}$ & $\begin{array}{l}\text { Has caused severe respiratory illness and can be excreted in faeces. Survives in sewage for } 2 \\
\text { days at } 20^{\circ} \mathrm{C} \text { and } 14 \text { days at } 4{ }^{\circ} \mathrm{C} \text { [278]. Possible contamination of bathing waters during } \\
\text { outbreak. Possible aerosolisation in buildings. }\end{array}$ & Weak & $\mathrm{NE}$ & Unknown & $\mathrm{NE}$ \\
\hline $\begin{array}{l}\text { Cryptosporidium } \\
\text { spp. }\end{array}$ & $\begin{array}{l}\text { Cause diarrhoea in young mammals and in humans but cannot grow in the environment. } \\
\text { Large waterborne outbreaks have been reported throughout the world. Oocysts are excreted } \\
\text { in faeces and sewage. Many species (C. hominis, C. parvum, C. meleagridis, C. cuniculus, C. } \\
\text { ubiquitum, C. viatorum, C. canis, C. felis, C. suis, C. scrofarum, C. bovis, and C. muris) and } \\
\text { genotypes of C. parvum) can cause human disease. Rainfall can contribute to drinking water } \\
\text { contamination from both human and animal faeces [279]. }\end{array}$ & Strong & $\begin{array}{l}{[28,138,187} \\
190,271-274 \\
280-285]\end{array}$ & Waterborne & $\begin{array}{l}\text { SA [286] SFA [287]; } \\
\text { OI [288-292]; } \\
\text { POWE [202]; FTA } \\
\text { [293]; RSA [294] }\end{array}$ \\
\hline Cyanobacteria & $\begin{array}{l}\text { Grow as blooms or mats, mostly within fresh water bodies. There are a large variety of } \\
\text { species, many producing potent toxins that can cause acute and chronic disease in mammals, } \\
\text { including man. The toxins include microcystins, nodularins, anatoxins, Saxitoxins, } \\
\text { aplysiatoxins, cylindrospremopsins, beta-methyl-amino-L-alanine (BMAA) and } \\
\text { lipopolysaccharides. Algal blooms are more commonly found in eutrophic (eutrophic waters } \\
\text { have a high concentration of nutrients) inland waters. Human health risks arise if the water } \\
\text { is consumed untreated, if people bathe or participate in water contact sports in waters with a } \\
\text { scum or heavy bloom and if contaminated water is used in renal dialysis. There have been } \\
\text { some notable outbreaks associated with cyanobacterial toxins with a high mortality rate in } \\
\text { dialysis patients. There are also associations between exposure to cyanobacterial toxins and } \\
\text { long-term health risks including cancer. The risks from BMAA linked to neurological disease } \\
\text { are unclear. Climate influence on algal blooms. Human recreational and drinking water } \\
\text { exposures. }\end{array}$ & $\begin{array}{l}\text { Strong for } \\
\text { outbreaks linked } \\
\text { to peritoneal } \\
\text { dialysis. }\end{array}$ & {$[295,296]$} & $\begin{array}{l}\text { Water } \\
\text { toxicosis }\end{array}$ & $\mathrm{CEO}$ \\
\hline $\begin{array}{l}\text { Cyanobacteria- } \\
\text { Anabena spp. }\end{array}$ & $\begin{array}{l}\text { Found in eutrophic waters. Has caused liver damage and deaths in waterfowl, sheep, cattle } \\
\text { and other agricultural animals. Vibrio cholerae has been found to survive for long periods } \\
\text { inside A. variabilis. Toxin producing species include A. flos-aquae, A. lemmermannii, A. } \\
\text { circinalis, A. millerii and A. planctonica. }\end{array}$ & Weak & $\mathrm{NE}$ & $\begin{array}{l}\text { Potential } \\
\text { water } \\
\text { toxicosis }\end{array}$ & $\mathrm{NE}$ \\
\hline $\begin{array}{l}\text { Cyanobacteria- } \\
\text { Aphanisomenon } \\
\text { spp. }\end{array}$ & $\begin{array}{l}\text { Produce the toxins anatoxin-a, saxitoxins and cylindrospermopsin. Toxin producing species } \\
\text { includes A. ovalisporum. }\end{array}$ & None & $\mathrm{NE}$ & $\begin{array}{l}\text { Potential } \\
\text { water } \\
\text { toxicosis }\end{array}$ & $\mathrm{NE}$ \\
\hline $\begin{array}{l}\text { Cyanobacteria- } \\
\text { Anacystis spp. }\end{array}$ & A. nidulans can produce lipopolysaccharide toxin. & None & $\mathrm{NE}$ & $\begin{array}{l}\text { Potential } \\
\text { water } \\
\text { toxicosis }\end{array}$ & $\mathrm{NE}$ \\
\hline
\end{tabular}


Table A1. Cont.

\begin{tabular}{|c|c|c|c|c|c|}
\hline Pathogen & How Climate Might Affect Disease Occurrence & $\begin{array}{l}\text { Strength of } \\
\text { Evidence for } \\
\text { Water Related } \\
\text { Infections }\end{array}$ & $\begin{array}{l}\text { Human } \\
\text { Waterborne } \\
\text { Outbreaks or } \\
\text { Infections }\end{array}$ & $\begin{array}{l}\text { Type of } \\
\text { Infection } \\
\text { Route }\end{array}$ & $\begin{array}{l}\text { Study Linking } \\
\text { Weather/Climate } \\
\text { and Infection }\end{array}$ \\
\hline $\begin{array}{l}\text { Cyanobacteria- } \\
\text { Cylindrospermopsis } \\
\text { raciborskii }\end{array}$ & $\begin{array}{l}\text { Found in eutrophic waters and produces anatoxin-a. Palm Island Mystery Disease in } \\
\text { Queensland, Australia caused } 140 \text { children to be hospitalised with a variety of symptoms } \\
\text { including malaise, anorexia, vomiting, headache, liver enlargement, bloody diarrhoea and } \\
\text { kidney damage. Water from a dam contaminated with C. raciborskii was thought to have been } \\
\text { responsible. }\end{array}$ & Strong & {$[297,298]$} & $\begin{array}{l}\text { Water } \\
\text { toxicosis }\end{array}$ & $\mathrm{NE}$ \\
\hline $\begin{array}{l}\text { Cyanobacteria- } \\
\text { Lyngbya majuscule }\end{array}$ & $\begin{array}{l}\text { A marine cyanobacteria that produces a variety of toxic metabolites including apratoxin A, } \\
\text { Palau'amide, 15-norlyngbyapeptin A and lyngbyabellin D, a quinoline alkaloid, } \\
\text { malyngamide T and the potent neurotoxins antillatoxin, antillatoxin B, and kalkitoxin. } \\
\text { Debromoaplysiatoxin has been isolated from Lyngbya gracilis also has dermonecrotic activity } \\
\text { and may be the dermatitis-producing substance in L. majuscula, the causative agent of } \\
\text { "swimmers' itch" outbreaks in Hawaiian waters. }\end{array}$ & Moderate & [299] & $\begin{array}{l}\text { Water } \\
\text { toxicosis }\end{array}$ & $\mathrm{NE}$ \\
\hline $\begin{array}{l}\text { Cyanobacteria- } \\
\text { Microcystis spp. }\end{array}$ & $\begin{array}{l}\text { M. aeruginosa is a common cyanobacteria found in eutrophic waters. It can cause hepatic } \\
\text { failure and diarrhoea in man and other animals. An association was found between drinking } \\
\text { water from a reservoir contaminated with M. aeruginosa and raised liver enzymes in a } \\
\text { population in New South Wales, Australia. Other toxic species include } M \text {. viridis and } M \text {. } \\
\text { botrys. }\end{array}$ & Strong & [300-302] & $\begin{array}{l}\text { Water } \\
\text { toxicosis }\end{array}$ & GDSE [303] \\
\hline $\begin{array}{l}\text { Cyanobacteria- } \\
\text { Nodularia spp. }\end{array}$ & $\begin{array}{l}\text { N. spumigena can cause poisoning of cattle and sheep which drink contaminated water. The } \\
\text { nodularin toxin is hepatotoxic. }\end{array}$ & Weak & NE & $\begin{array}{l}\text { Potential } \\
\text { water } \\
\text { toxicosis }\end{array}$ & $\mathrm{NE}$ \\
\hline $\begin{array}{l}\text { Cyanobacteria- } \\
\text { Nostoc spp. }\end{array}$ & $\begin{array}{l}\text { Produce microcystins and the beta-methyl-amino-L-alanine (BMAA) that has been } \\
\text { implicated as the cause of neurodegenerative disease among the Chamorro people of Guam } \\
\text { (Guam disease). Evidence not conclusive. }\end{array}$ & Weak & $\mathrm{NE}$ & $\begin{array}{l}\text { Potential } \\
\text { water } \\
\text { toxicosis }\end{array}$ & $\mathrm{NE}$ \\
\hline $\begin{array}{l}\text { Cyanobacteria- } \\
\text { Oscillatoria spp. }\end{array}$ & $\begin{array}{l}\text { Produce anatoxin-a which can cause neurotoxicity leading to respiratory failure. } \\
\text { Consumption of water contaminated with the toxin has been associated with liver cancer in } \\
\text { China and acute respiratory failure and death in dogs. Includes O. agardhii, O. nitroviridis and } \\
\text { O. limosa. }\end{array}$ & Moderate & NE & $\begin{array}{l}\text { Potential } \\
\text { water } \\
\text { toxicosis }\end{array}$ & $\mathrm{NE}$ \\
\hline $\begin{array}{l}\text { Cyanobacteria- } \\
\text { Planktothrix spp. }\end{array}$ & $\begin{array}{l}\text { Produces microcystins, anatoxin-a and homoanatoxin-a. The main toxin producing species } \\
\text { are P. agardhii, P. mougeotii and P. formosa. }\end{array}$ & None & $\mathrm{NE}$ & $\begin{array}{l}\text { Potential } \\
\text { water } \\
\text { toxicosis }\end{array}$ & $\mathrm{NE}$ \\
\hline $\begin{array}{l}\text { Cyanobacteria- } \\
\text { Phormidium spp. }\end{array}$ & $\begin{array}{l}\text { P. favosum is a cyanobacterium that produces anatoxin-a and has been associated with } \\
\text { neurotoxicosis in dogs. Toxin producing species include } P \text {. bijugatum, } P \text {. molle, } P \text {. papyraceum, } \\
\text { P. uncinatum and } P \text {. autumnale. Toxin producing strains have been found in water from } \\
\text { reservoirs in Australia. }\end{array}$ & None & $\mathrm{NE}$ & $\begin{array}{l}\text { Potential } \\
\text { water } \\
\text { toxicosis }\end{array}$ & $\mathrm{NE}$ \\
\hline
\end{tabular}


Table A1. Cont.

\begin{tabular}{|c|c|c|c|c|c|}
\hline Pathogen & How Climate Might Affect Disease Occurrence & $\begin{array}{l}\text { Strength of } \\
\text { Evidence for } \\
\text { Water Related } \\
\text { Infections }\end{array}$ & $\begin{array}{l}\text { Human } \\
\text { Waterborne } \\
\text { Outbreaks or } \\
\text { Infections }\end{array}$ & $\begin{array}{l}\text { Type of Infection } \\
\text { Route }\end{array}$ & $\begin{array}{l}\text { Study Linking } \\
\text { Weather/Climate } \\
\text { and Infection }\end{array}$ \\
\hline $\begin{array}{l}\text { Cyanobacteria- } \\
\text { Raphidiopsis }\end{array}$ & $\begin{array}{l}\text { R. mediterranea can produce the toxins homoanatoxin-a, anatoxin-a, and non-toxic } \\
\text { 4-hydroxyhomoanatoxin-a. }\end{array}$ & None & NE & $\begin{array}{l}\text { Potential water } \\
\text { toxicosis }\end{array}$ & NE \\
\hline $\begin{array}{l}\text { Cyanobacteria- } \\
\text { Trichodesmium }\end{array}$ & $\begin{array}{l}\text { T. erythraeum is a marine cyanobacteria that is reported to produce a neurotoxin. This } \\
\text { organism contributes to some ciguatera toxin accumulation in fish. }\end{array}$ & Moderate & NE & $\begin{array}{l}\text { Potential water } \\
\text { toxicosis }\end{array}$ & NE \\
\hline $\begin{array}{l}\text { Cyanobacteria- } \\
\text { Umezakia natans }\end{array}$ & Produces the toxin cylindrospermopsin. & None & NE & $\begin{array}{l}\text { Potential water } \\
\text { toxicosis }\end{array}$ & NE \\
\hline $\begin{array}{l}\text { Cyclospora } \\
\text { cayetanensis }\end{array}$ & $\begin{array}{l}\text { Contaminated water applied to salads and soft fruits through irrigation/spraying. } \\
\text { Repeated outbreaks linked to Mexico. }\end{array}$ & Strong & $\begin{array}{l}{[189,190,271-} \\
274,304,305]\end{array}$ & $\begin{array}{l}\text { Waterborne, Water } \\
\text { contaminated food }\end{array}$ & NE \\
\hline $\begin{array}{l}\text { Dinoflagellates } \\
\text { and diatoms }\end{array}$ & $\begin{array}{l}\text { These are protozoan organisms that can produce a range of potent toxins. They occur } \\
\text { predominantly in saltwater and, under the right conditions, can produce blooms that } \\
\text { cause 'red tides' that can cause toxic effects in fish and other sea-life. The toxins can } \\
\text { accumulate within shellfish, causing paralytic shellfish poisoning (PSP), diarrhoretic } \\
\text { shellfish poisoning (DSP), neurotoxic shellfish poisoning (NSP), Amnesic Shellfish } \\
\text { Poisoning (ASP). Some of the toxins can also accumulate through passing up the food } \\
\text { chain to give carnivorous fish that are toxic (ciguatera toxin). Coastal blooms causing } \\
\text { respiratory symptoms, ciguatera and shellfish poisoning. Blooms of dinoflagellates are } \\
\text { linked to weather and nutrients. }\end{array}$ & Strong & [306-324] & $\begin{array}{l}\text { Toxin contamination } \\
\text { of marine foods }\end{array}$ & CEO [325] \\
\hline $\begin{array}{l}\text { Diatom-Nitzschia } \\
\text { spp., } \\
\text { Pseudo-nitzschia } \\
\text { spp. \& Amphora } \\
\text { spp. Amnesic } \\
\text { Shellfish } \\
\text { Poisoning }\end{array}$ & $\begin{array}{l}\text { Pseudo-nitzschia spp. And Nitzschia navis-varingica are diatoms that cause Amnesic } \\
\text { Shellfish Poisoning through the production of domoic acids. Symptoms include } \\
\text { dizziness, nausea, vomiting, cramps, diarrhoea, dizziness, headache, seizures, } \\
\text { disorientation, short-term memory loss, respiratory difficulty and coma. The toxins are } \\
\text { regularly detected in UK waters and shellfish. Blooms of Pseudo-nitzschia australis have } \\
\text { been implicated in deaths of fish and sea lions. Other species include P. calliantha, } P \text {. } \\
\text { delicatissima, P. fraudulenta, P. galaxiae, P. multiseries, P. multistriata, P. pungens, P. seriata, } \\
P \text {. turgidula. Amphora coffeaeformis is a diatom that produces domoic acid, but its role in } \\
\text { human disease is unclear. }\end{array}$ & Moderate & [326-329] & $\begin{array}{l}\text { Toxin contamination } \\
\text { of marine foods }\end{array}$ & NE \\
\hline
\end{tabular}


Table A1. Cont.

\begin{tabular}{|c|c|c|c|c|c|}
\hline Pathogen & How Climate Might Affect Disease Occurrence & $\begin{array}{l}\text { Strength of } \\
\text { Evidence for } \\
\text { Water Related } \\
\text { Infections }\end{array}$ & $\begin{array}{l}\text { Human } \\
\text { Waterborne } \\
\text { Outbreaks or } \\
\text { Infections }\end{array}$ & $\begin{array}{l}\text { Type of } \\
\text { Infection } \\
\text { Route }\end{array}$ & $\begin{array}{l}\text { Study Linking } \\
\text { Weather/Climate } \\
\text { and Infection }\end{array}$ \\
\hline $\begin{array}{l}\text { Dinoflagellate- } \\
\text { Alexandrium spp., } \\
\text { Pyrodinium spp. \& } \\
\text { Gymnodinium spp. } \\
\text { Paralytic Shellfish } \\
\text { Poisoning }\end{array}$ & $\begin{array}{l}\text { Cause Paralytic Shellfish Poisoning (PSP) through toxin accumulation in bivalve molluscs. } \\
\text { They can also cause mass fish kills. Species include A. acatenella, A. andersonii, A. balechii, A. } \\
\text { catenella, A. fundyense, A. hiranoi, A. minutum, A. monilatum, A. ostenfeldi and A. tamiyavanichii. } \\
\text { The toxins include saxitoxin and neosaxitoxin, spirolide, goniodomin A. Change in algal } \\
\text { blooms with climate. Transmission through shellfish. Gymnodinium catenatum produces red } \\
\text { tides and high mortality in fishes and can also cause Paralytic Shellfish Poisoning (PSP). } \\
\text { Pyrodinium bahamense var. compressa can produce red tides has been implicated in PSP. }\end{array}$ & Strong & [189] & $\begin{array}{l}\text { Toxin } \\
\text { contamination } \\
\text { of marine } \\
\text { foods }\end{array}$ & $\mathrm{NE}$ \\
\hline $\begin{array}{l}\text { Dinoflagellate- } \\
\text { Dinophysis spp. \& } \\
\text { Procentrum spp. } \\
\text { Diarrhoretic } \\
\text { Shellfish } \\
\text { Poisoning }\end{array}$ & $\begin{array}{l}\text { Cause Diarrhoretic Shellfish Poisoning (DSP) through accumulation of the toxins in bivalve } \\
\text { molluscs. The toxins include okadaic acid, dinophysistoxin-1 (DTX1), dinophysistoxin-2 } \\
\text { (DTX2) and pectenotoxin-2 (PTX2). The implicated species include D. acuminata, D. acuta, D. } \\
\text { caudata, D. fortii, D. miles, D. mitra, D. norvegica, D. rapa, D. rotundata, D. sacculus and D. tripos. } \\
\text { Procentrum arenarium, P. belizeanum, P. cassubicum, P. faustiae, P. hoffmannianum, P. lima, } P \text {. } \\
\text { maculosum produce one or more toxins including okadaic acid, DTX1, DTX-2, prorocentrolide } \\
\text { and fast acting toxins (FAT). Other species with less evidence of toxicity include } P \text {. } \\
\text { borbonicum, } P \text {. concavum, P. emarginatum, P. minimum, P. emarginatum, P. minimum, } P \text {. } \\
\text { mexicanum, P. arabianum. }\end{array}$ & Strong & $\begin{array}{l}{[318,319,330,} \\
331]\end{array}$ & $\begin{array}{l}\text { Toxin } \\
\text { contamination } \\
\text { of marine } \\
\text { foods }\end{array}$ & $\mathrm{NE}$ \\
\hline $\begin{array}{l}\text { Dinoflagellate- } \\
\text { Karenia spp. } \\
\text { Neurotoxic } \\
\text { Shellfish } \\
\text { Poisoning }\end{array}$ & $\begin{array}{l}\text { The species K. bicuneiformis, K. brevis, K. brevisulcata, K. concordia, K. cristata, K. mikimotoi, K. } \\
\text { papilionacea, K. selliformis, K. umbella produce red tides and can cause Neurotoxic Shellfish } \\
\text { Poisoning (NSP). They also cause high mortality in fishes, invertebrates, marine animals and } \\
\text { plants, and human respiratory distress, eye and skin irritations. Most species produce } \\
\text { brevetoxin in culture. K. brevis is synonymous with Gymnodinium brevis and Ptychodiscus } \\
\text { brevis. }\end{array}$ & Moderate & [309] & $\begin{array}{l}\text { Toxin } \\
\text { contamination } \\
\text { of marine } \\
\text { foods }\end{array}$ & $\mathrm{NE}$ \\
\hline $\begin{array}{l}\text { Dinoflagellate- } \\
\text { Protoperidinium } \\
\text { Azaspiracid } \\
\text { Shellfish } \\
\text { Poisoning }\end{array}$ & $\begin{array}{l}\text { P. crassipes produces azaspiracid, which gives DSP-like symptoms of Azaspiracid Shellfish } \\
\text { Poisoning in humans but a mixture of DSP-and neurotoxin-like effects in mice. }\end{array}$ & None & {$[332]$} & $\begin{array}{l}\text { Toxin } \\
\text { contamination } \\
\text { of marine } \\
\text { foods }\end{array}$ & $\mathrm{NE}$ \\
\hline $\begin{array}{l}\text { Dinoflagellate- } \\
\text { Gambierdiscus spp. } \\
\text { \& Gonyaulax } \\
\text { tamarensis. } \\
\text { Ciguatera food } \\
\text { poisoning }\end{array}$ & $\begin{array}{l}\text { Produce ciguatoxin or maitotoxin that can pass up the food chain and accumulate in } \\
\text { dangerous amounts in certain species of carnivorous fish and shellfish accumulate the toxins } \\
\text { as they pass up the food chain. Ciguatera food poisoning produces gastrointestinal, } \\
\text { neurological, and cardiovascular symptoms including diarrhoea, vomiting, abdominal pain, } \\
\text { reversal of temperature sensation, muscular aches, dizziness, anxiety, sweating, and a } \\
\text { numbness and tingling of the mouth and digits. Toxic species of Gambierdiscus include G. } \\
\text { pacificus, G. australes, G. yasumotoi and G. polynesiensis and Gonyaulax tamarensis. }\end{array}$ & Strong & {$[333-344]$} & $\begin{array}{l}\text { Toxin } \\
\text { contamination } \\
\text { of marine } \\
\text { foods }\end{array}$ & $\mathrm{NE}$ \\
\hline
\end{tabular}


Table A1. Cont.

\begin{tabular}{|c|c|c|c|c|c|}
\hline Pathogen & How Climate Might Affect Disease Occurrence & $\begin{array}{l}\text { Strength of } \\
\text { Evidence for } \\
\text { Water Related } \\
\text { Infections }\end{array}$ & $\begin{array}{l}\text { Human } \\
\text { Waterborne } \\
\text { Outbreaks or } \\
\text { Infections }\end{array}$ & $\begin{array}{l}\text { Type of } \\
\text { Infection } \\
\text { Route }\end{array}$ & $\begin{array}{l}\text { Study Linking } \\
\text { Weather/Climate } \\
\text { and Infection }\end{array}$ \\
\hline $\begin{array}{l}\text { Dinoflagellate- } \\
\text { Ostreopsis spp. }\end{array}$ & $\begin{array}{l}\text { Ostreopsis lenticularis is the presumed vector of ciguatera poisoning in the Caribbean. The } \\
\text { toxin accumulates through the food chain and can be present in toxic amounts in carnivorous } \\
\text { fish. O. siamensis produces ostreocin D, a palytoxin analogue and has been implicated in } \\
\text { clupeotoxism, a fatal toxicosis through ingestion of clupeoid fish (sardines, anchovies and } \\
\text { herring). O. lenticularis produces ostreotoxin- } 1 \text { and -3, palytoxin analogues (polyethers), } \\
\text { mascarenotoxin-A and -B. O. mascarenensis is possibly responsible for palytoxin poisoning, } \\
\text { which in humans results in cramps, nausea, diarrhoea, etc, after eating of crabs and certain } \\
\text { fish. O. ovata is also be a toxin producer and has been associated with toxic effects of bathing } \\
\text { in a bloom of this organism (nausea, breathing difficulties, high fever, stomach cramps, } \\
\text { irritation of the eyes, vomiting and diarrhea) in Italy. }\end{array}$ & Strong & {$[308,345]$} & $\begin{array}{l}\text { Toxin } \\
\text { contamination } \\
\text { of marine } \\
\text { foods; } \\
\text { Potential } \\
\text { water } \\
\text { toxicosis }\end{array}$ & NE \\
\hline $\begin{array}{l}\text { Dinoflagellate- } \\
\text { Hematodinium spp. }\end{array}$ & $\begin{array}{l}\text { Cause Bitter Crab Disease and Pink Crab Disease in crabs, making them unpalatable. There } \\
\text { is little evidence for a health risk associated with the consumption of infected crabs. }\end{array}$ & None & $\mathrm{NE}$ & $\begin{array}{l}\text { Potential } \\
\text { water } / \text { food } \\
\text { toxicosis }\end{array}$ & $\mathrm{NE}$ \\
\hline $\begin{array}{l}\text { Dinoflagellate- } \\
\text { Heterocapsa spp. }\end{array}$ & $\begin{array}{l}\text { H. circularisquama forms red tides and can cause mass fish kills. Their role in human disease } \\
\text { remains unclear. }\end{array}$ & & $\mathrm{NE}$ & $\begin{array}{l}\text { Potential } \\
\text { water } / \text { food } \\
\text { toxicosis }\end{array}$ & NE \\
\hline $\begin{array}{l}\text { Dinoflagellate- } \\
\text { Pfiesteria spp. }\end{array}$ & $\begin{array}{l}\text { Pfiesteria piscicida is a dinoflagellate that resides in estuarine waters and is responsible for } \\
\text { mass fish kills. It has been associated with skin and neurological problems in humans } \\
\text { exposed to the toxins, but this work has been challenged. Pfiesteria shumwayae causes mass } \\
\text { fish kills in estuarine waters. No human illness has yet been associated with this organism. }\end{array}$ & Weak & $\mathrm{NE}$ & Unknown & $\mathrm{NE}$ \\
\hline $\begin{array}{l}\text { Dinoflagellate- } \\
\text { Protoceratium } \\
\text { reticulatum }\end{array}$ & $\begin{array}{l}\text { P. reticulatum produces yessotoxin which may accumulate in bivalves and is toxic to mice. Its } \\
\text { role in human disease is unclear. }\end{array}$ & None & $\mathrm{NE}$ & Unknown & NE \\
\hline $\begin{array}{l}\text { Dracunculus } \\
\text { medinensis }\end{array}$ & $\begin{array}{l}\text { Dracunculus medinensis life cycle involves the water flea Cyclops. It is the cause of } \\
\text { dracontiasis. Human infection results from the consumption of water contaminated with } \\
\text { infected water fleas. The adult worm emerges on the foot or leg, and rhabditoid larvae are } \\
\text { released into the water where they re-infect water fleas. There is a WHO lead worldwide } \\
\text { programme to eradicate Guinea Worm. Rainfall contamination of source waters. Infection } \\
\text { associated with water scarcity and start of rainy season. }\end{array}$ & Strong & {$[346-351]$} & Waterborne & RSA $[352,353]$ \\
\hline $\begin{array}{l}\text { Entamoeba } \\
\text { histolytica }\end{array}$ & $\begin{array}{l}\text { Causes invasive amoebic dysentery, with abscess formation in the liver and other body sites. } \\
\text { Colonisation may occur through water contaminated with the cysts, often in developing } \\
\text { countries where it is endemic. People infected with this organism have usually been } \\
\text { travelling abroad recently. E. histolytica is visually similar but genetically distinct from } E \text {. } \\
\text { dispar. A few waterborne outbreaks. }\end{array}$ & Moderate & $\begin{array}{l}{[187,189,190,} \\
258,271-274 \\
354,355]\end{array}$ & Waterborne & $\mathrm{NE}$ \\
\hline
\end{tabular}


Table A1. Cont.

\begin{tabular}{|c|c|c|c|c|c|}
\hline Pathogen & How Climate Might Affect Disease Occurrence & $\begin{array}{l}\text { Strength of } \\
\text { Evidence for } \\
\text { Water Related } \\
\text { Infections }\end{array}$ & $\begin{array}{l}\text { Human } \\
\text { Waterborne } \\
\text { Outbreaks or } \\
\text { Infections }\end{array}$ & $\begin{array}{l}\text { Type of } \\
\text { Infection } \\
\text { Route }\end{array}$ & $\begin{array}{l}\text { Study Linking } \\
\text { Weather/Climate } \\
\text { and Infection }\end{array}$ \\
\hline $\begin{array}{l}\text { Other Entamoeba } \\
\text { spp. }\end{array}$ & $\begin{array}{l}\text { Entamoeba coli, E. dispar and E. moshnikovii can colonise the human intestinal tract and is } \\
\text { incapable of causing the invasive form of amoebic dysentery, and is not thought to be an } \\
\text { enteric pathogen. Endolimax nana, Enteromonas hominis, Retortomonas intestinalis, Iodamoeba } \\
\text { butschlii, Pentatrichomonas hominis, Trichomonas hominis are thought to be non-pathogenic. } \\
\text { They are probably transmitted by contaminated food and water, and can be found in patients } \\
\text { with diarrhoea. No evidence of rainfall impact. }\end{array}$ & Weak & $\mathrm{NE}$ & Unknown & NE \\
\hline Echinococcus spp. & $\begin{array}{l}\text { Main species E. granulosus and E.multilocularis and rarer species E. vogeli and E.oligarthrus. E. } \\
\text { granulosus forms hydatids (fluid filled vacuoles) in wild ruminants, sheep, pigs, cattle and } \\
\text { man, E. g. equinus in horses but not man, E. g. canadensis in caribou, reindeer and man and E. } \\
\text { g. borealis cervids and man. E. multilocularis has subspecies including E. m. multilocularis in } \\
\text { Europe and E. m. sibiricencis in North America. E. vogeli in South American Bush dogs with } \\
\text { hydatids in rodents. E. oligarthrus in wild cats with hydatids in rodents. Infection results from } \\
\text { consumption of Echinococcus ova and has been linked to the consumption of contaminated } \\
\text { drinking water and direct contamination from dogs or foxes. Strong epidemiological } \\
\text { association with drinking water contamination. Rainfall may contribute to contamination. }\end{array}$ & Strong & [356-363] & Waterborne & $\mathrm{NE}$ \\
\hline $\begin{array}{l}\text { Enterobius } \\
\text { vermicularis }\end{array}$ & $\begin{array}{l}\text { No waterborne outbreaks but sporadic infection related to drinking water quality. No } \\
\text { weather associations. }\end{array}$ & Weak & [364-366] & Waterborne & NE \\
\hline $\begin{array}{l}\text { Enteroviruses } \\
\text { including } \\
\text { coxsackie, ECHO, } \\
\text { polio }\end{array}$ & Gross contamination of drinking water leading to enterovirus outbreaks. & Moderate & {$[197,367-373]$} & Waterborne & $\begin{array}{l}\text { OI [373], QMRA } \\
\text { [374] }\end{array}$ \\
\hline $\begin{array}{l}\text { Enterovirus- } \\
\text { Coxsackievirus A } \\
\text { and B }\end{array}$ & $\begin{array}{l}\text { Cause mycocarditis, pericarditis, skin rash, meningitis, respiratory infections and fever and } \\
\text { are transmitted through the faecal-oral route. Coxsackie A can cause hand, foot and mouth } \\
\text { disease, herpangina (fever, sore throat, pain on swallowing, anorexia and vomiting) and } \\
\text { conjunctivitis. Coxsackie B can cause pleurodynia (chest pain) and severe infections in } \\
\text { neonates. Outbreaks of Bornholm disease do not show evidence of being waterborne. }\end{array}$ & Weak & NE & $\begin{array}{l}\text { Not } \\
\text { waterborne }\end{array}$ & NE \\
\hline $\begin{array}{l}\text { Enterovirus- } \\
\text { Echovirus }\end{array}$ & $\begin{array}{l}\text { These enteric viruses usually manifest themselves as a maculopapular skin rash but can also } \\
\text { cause meningitis. There are a number of serotypes. }\end{array}$ & Weak & [375-377] & Waterborne & NE \\
\hline $\begin{array}{l}\text { Enterovirus- } \\
\text { Parechovirus }\end{array}$ & $\begin{array}{l}\text { Parechovirus type } 1(\mathrm{PeV} 1) \text { and type } 2(\mathrm{PeV} 2) \text { were previously known as echovirus } 22 \text { and } \\
\text { echovirus } 23 \text {, but there are six types. Infections can include meningoencephalitis, fever and } \\
\text { myositis and may play a role in intra-uterine fetal deaths. Parechoviruses have been isolated } \\
\text { from some patients with gastroenteritis. PeV1 has been associated with otitis media and } \\
\text { cough. }\end{array}$ & Weak & NE & Unknown & NE \\
\hline
\end{tabular}


Table A1. Cont.

\begin{tabular}{|c|c|c|c|c|c|}
\hline Pathogen & How Climate Might Affect Disease Occurrence & $\begin{array}{l}\text { Strength of } \\
\text { Evidence for } \\
\text { Water Related } \\
\text { Infections }\end{array}$ & $\begin{array}{l}\text { Human } \\
\text { Waterborne } \\
\text { Outbreaks or } \\
\text { Infections }\end{array}$ & $\begin{array}{l}\text { Type of } \\
\text { Infection } \\
\text { Route }\end{array}$ & $\begin{array}{l}\text { Study Linking } \\
\text { Weather/Climate } \\
\text { and Infection }\end{array}$ \\
\hline $\begin{array}{l}\text { Enteroviruses- } \\
\text { Poliovirus }\end{array}$ & $\begin{array}{l}\text { There are three poliovirus types that have been eradicated from the UK. The WHO is } \\
\text { organising the worldwide eradication of poliovirus. Wildtype WPV2 poliovirus was last } \\
\text { observed in October 1999. Strategies for eradication include expanded use of type } 1 \\
\text { monovalent oral poliovirus vaccine (mOPV1) to eliminate WPV1 transmission before WPV3 } \\
\text { and targeted use of type } 3 \text { monovalent vaccine mOPV3 in selected areas. }\end{array}$ & Weak & $\mathrm{NE}$ & Unknown & NE \\
\hline Escherichia coli & $\begin{array}{l}\text { Escherichia coli contain both non-pathogenic organisms and strains that are an important } \\
\text { cause of diarrhoeal disease (termed enterovirulent } E \text {. coli). Several classes have been defined } \\
\text { based on the possession of distinct virulence factors. These are the enteropathogenic (EPEC), } \\
\text { enterotoxigenic (ETEC), enteroinvasive (EIEC) and Vero cytotoxigenic (VTEC), } \\
\text { enteroaggregative (EAggEC) and diffusely adherent (DAEC) strains of E. coli. In developing } \\
\text { countries food and contaminated water are important vehicles for transmission of E. coli. } \\
\text { These are less common in developed countries where there are higher standards of general } \\
\text { hygiene. }\end{array}$ & Strong & {$[35,378-390]$} & Waterborne & NE \\
\hline $\begin{array}{l}\text { Escherichia coli- } \\
\text { enteropathogenic } \\
\text { (EPEC) }\end{array}$ & $\begin{array}{l}\text { The classical enteropathogenic E. coli (EPEC) belong to a small number of serotypes and } \\
\text { cause sporadic cases and outbreaks of diarrhoea in children, usually under the age of } 2 \text { years. } \\
\text { A wider range of EPEC strains have caused sporadic cases and outbreaks affecting adults. }\end{array}$ & Weak & {$[378]$} & Waterborne & $\mathrm{NE}$ \\
\hline $\begin{array}{l}\text { Escherichia coli- } \\
\text { enterotoxigenic } \\
\text { (ETEC) }\end{array}$ & Common cause of traveller's diarrhoea that can be transmitted by water. & Strong & {$[35,379-383]$} & Waterborne & NE \\
\hline $\begin{array}{l}\text { Escherichia coli- } \\
\text { enteroinvasive } \\
\text { (EIEC) }\end{array}$ & Transmission through poor hygiene or contaminated food or water. & Moderate & [384] & Waterborne & NE \\
\hline $\begin{array}{l}\text { Escherichia coli- } \\
\text { Shiga } \\
\text { cytotoxigenic } \\
\text { (STEC; VTEC; } \\
\text { EHEC) }\end{array}$ & Infection through contaminated drinking water-heavy rainfall. & Strong & [385-390] & Waterborne & CA [391]; OI [109] \\
\hline $\begin{array}{l}\text { Escherichia coli- } \\
\text { enteroaggregative } \\
\text { (EAggEC) }\end{array}$ & $\begin{array}{l}\text { Enteroaggregative E. coli (EAggEC) cause sporadic cases and outbreaks affecting all ages and } \\
\text { like Enterotoxigenic E. coli (ETEC) are a major cause of travellers' diarrhoea. }\end{array}$ & Moderate & [392] & Waterborne & $\mathrm{NE}$ \\
\hline $\begin{array}{l}\text { Escherichia coli- } \\
\text { diffusely adherent } \\
\text { (DAEC) }\end{array}$ & Transmission poorly understood. & $\mathrm{NE}$ & $\mathrm{NE}$ & Unknown & $\mathrm{NE}$ \\
\hline
\end{tabular}


Table A1. Cont.

\begin{tabular}{|c|c|c|c|c|c|}
\hline Pathogen & How Climate Might Affect Disease Occurrence & $\begin{array}{l}\text { Strength of } \\
\text { Evidence for } \\
\text { Water Related } \\
\text { Infections }\end{array}$ & $\begin{array}{l}\text { Human } \\
\text { Waterborne } \\
\text { Outbreaks or } \\
\text { Infections }\end{array}$ & $\begin{array}{l}\text { Type of } \\
\text { Infection } \\
\text { Route }\end{array}$ & $\begin{array}{l}\text { Study Linking } \\
\text { Weather/Climate } \\
\text { and Infection }\end{array}$ \\
\hline Fasciola gigantica & $\begin{array}{l}\text { A liver fluke (helminth) that is common in cattle in the Middle East, Africa and Asia. The } \\
\text { parasite requires a snail as an intermediate host, and man is infected through the } \\
\text { consumption of aquatic plants contaminated with the metacercaria. }\end{array}$ & Moderate & [393] & Water based & NE \\
\hline Fasciola hepatica & $\begin{array}{l}\text { A liver fluke (helminth) that is common in herbivores that graze in wet pasture. The parasite } \\
\text { requires a snail as an intermediate host, and man is occasionally infected through the } \\
\text { consumption of aquatic plants, particularly watercress, contaminated with the metacercaria. }\end{array}$ & Strong & [394] & Water based & RAI [395-499] \\
\hline Fasciolopsis buski & $\begin{array}{l}\text { An intestinal fluke (helminth) that is common in areas of Indonesia and Northern Thailand } \\
\text { and the Far East. The parasite requires a snail as an intermediate host, and man is infected } \\
\text { through the consumption of aquatic plants, particularly water chestnuts and water caltrop, } \\
\text { contaminated with the metacercaria. }\end{array}$ & Moderate & [400] & Water based & $\mathrm{NE}$ \\
\hline Giardia spp. & $\begin{array}{l}\text { Grows attached to the small intestinal lining and causes malabsorption in people. The } \\
\text { parasite can be isolated from the faeces of wild and domestic animals, and waterborne } \\
\text { outbreaks are usually associated with recreational water use. The parasite cyst, which is } \\
\text { found in faeces, is moderately resistant to chlorine. The modes of transmission remain } \\
\text { unclear. Giardia can be transmitted through recreational and drinking water, although } \\
\text { hygiene is also important. }\end{array}$ & Strong & $\begin{array}{l}{[28,143,271-} \\
274,281,283 \\
401,402]\end{array}$ & Waterborne & CSS [403] \\
\hline $\begin{array}{l}\text { Gongylonema } \\
\text { pulchrum }\end{array}$ & $\begin{array}{l}\text { Occurs commonly in domestic cattle and other vertebrates, but gongylonemiasis is very rare } \\
\text { in humans. Only } 48 \text { cases have been described in the literature since } 1864 \text {. An infection in } \\
\text { Hungary was linked to ingestion of contaminated water from an open draw well. }\end{array}$ & Moderate & NE & Water based & $\mathrm{NE}$ \\
\hline Helicobacter pylori & $\begin{array}{l}\text { H. pylori is associated with gastritis, and with gastric and duodenal ulcers. The mode of } \\
\text { transmission is not entirely understood. The reservoir of H. pylori is the digestive tracts of } \\
\text { humans and some primates, and transmission is considered to be from person-to-person } \\
\text { with the most common route being oral-oral. H. pylori is shed in the faeces after turnover of } \\
\text { the gastric mucosa, and has been detected by PCR in sewage in Peru. Sewage pollution is } \\
\text { therefore a possible though not proven route of transmission. }\end{array}$ & Moderate & {$[404-415]$} & Waterborne & NE \\
\hline Helicobacter spp. & $\begin{array}{l}\text { Is larger and more tightly helical than } H \text {. pylori and is associated with a small percentage of } \\
\text { patients with gastritis. Helicobacter bilis is a Gram negative spiral bacterium that is regarded } \\
\text { as an enteric helicobacter and has been implicated in liver disease, particularly biliary tract } \\
\text { cancer. Other enteric helicobacters that may be implicated in liver or intestinal disease } \\
\text { include H. hepaticus, H. rappani and H. pullorum. Helicobacter winghamensis is a Helicobacter sp. } \\
\text { that have been isolated from patients with gastroenteritis. It's role as a cause of diarrhoea has } \\
\text { not been demonstrated. H. pylori can contaminate drinking water sources and infection is } \\
\text { associated with drinking water source. No evidence of climate drivers. }\end{array}$ & None & $\mathrm{NE}$ & Unknown & $\mathrm{NE}$ \\
\hline
\end{tabular}


Table A1. Cont.

\begin{tabular}{|c|c|c|c|c|c|}
\hline Pathogen & How Climate Might Affect Disease Occurrence & $\begin{array}{l}\text { Strength of } \\
\text { Evidence for } \\
\text { Water Related } \\
\text { Infections }\end{array}$ & $\begin{array}{l}\text { Human } \\
\text { Waterborne } \\
\text { Outbreaks or } \\
\text { Infections }\end{array}$ & $\begin{array}{l}\text { Type of } \\
\text { Infection } \\
\text { Route }\end{array}$ & $\begin{array}{l}\text { Study Linking } \\
\text { Weather/Climate } \\
\text { and Infection }\end{array}$ \\
\hline Hepatitis A & $\begin{array}{l}\text { Hepatitis A virus causes hepatitis and can be acquired by person-to-person, through } \\
\text { contaminated water, shellfish, and foods eaten raw or washed in contaminated water and } \\
\text { waterborne routes. Infection resulting from sewage contamination of source waters and } \\
\text { shellfish. Some rainfall associations. }\end{array}$ & Strong & $\begin{array}{l}{[198,200,416-} \\
424]\end{array}$ & Waterborne & $\begin{array}{l}\text { PORA = [425]; SFA } \\
{[426,427]}\end{array}$ \\
\hline Hepatitis E & $\begin{array}{l}\text { Hepatitis E virus has a genome of single stranded RNA. Epidemiological evidence suggests } \\
\text { that the disease can be transmitted by drinking water contaminated with faeces or contact } \\
\text { with an environment contaminated with faeces. Pigs may be an important reservoir of } \\
\text { infection. Infections in the UK are associated with overseas travel. Large waterborne } \\
\text { outbreaks }\end{array}$ & Strong & $\begin{array}{l}{[198,209,428-} \\
436]\end{array}$ & Waterborne & OI [428] \\
\hline Isospora belli & $\begin{array}{l}\text { A coccidian (protozoan) parasite related to Cryptosporidium and Cyclospora. Infection with } I \text {. } \\
\text { belli may cause colicky pain, diarrhoea, malabsorption and fever. Transmission of Isospora } \\
\text { belli to humans from contaminated water and infected animals is suspected but has not been } \\
\text { clearly demonstrated. Close contact in barracks or institutions, the presence of other } \\
\text { intestinal disease, and poor hygiene appear to favour transmission. Limited evidence of } \\
\text { waterborne transmission }\end{array}$ & Weak & [187] & Unknown & $\mathrm{NE}$ \\
\hline $\begin{array}{l}\text { Laribacter } \\
\text { hongkongensis }\end{array}$ & $\begin{array}{l}\text { An aerobic, spiral shaped gram-negative bacteria isolated from a few people suffering from } \\
\text { travel related diarrhoea. Cases were first identified in Hong Kong but have since occurred in } \\
\text { other parts of the World. It has also been isolated from freshwater fish in China. The } \\
\text { causative role of this organism in human gastroenteritis is still unproven. }\end{array}$ & None & $\mathrm{NE}$ & Unknown & $\mathrm{NE}$ \\
\hline $\begin{array}{l}\text { Legionella } \\
\text { pneumophila }\end{array}$ & Legionellosis linked to climate (humidity/vapour pressure) & Strong & {$[275,437-443]$} & $\begin{array}{l}\text { Aerosol } \\
\text { transmission }\end{array}$ & $\begin{array}{l}\text { PRA, RCCS } \\
{[158,444,445]} \\
\text { POCS [446]; OI } \\
{[447]}\end{array}$ \\
\hline Leptospira spp. & $\begin{array}{l}\text { Tightly coiled spiral bacteria that cause Weil's Disease (jaundice) in people. Infection is from } \\
\text { rodents and agricultural and domestic animals, usually through exposure to contaminated } \\
\text { water or urine. Drinking or exposing wounds or mucous membranes to contaminated water } \\
\text { can result in infection. Infection through natural water contaminated by rodent urine and } \\
\text { occasionally through unchlorinated drinking water. Outbreaks follow heavy rainfall and } \\
\text { flooding and occasionally abnormally low rainfall. }\end{array}$ & Strong & {$[36,448-455]$} & Waterborne & $\begin{array}{l}\text { [456]; OI } \\
\text { [160-162,457-468]; } \\
\text { RILO [469]; SA } \\
\text { [470]; RCS [471]; } \\
\text { NBM [472]; CSS } \\
\text { [473] }\end{array}$ \\
\hline Microsporidia & $\begin{array}{l}\text { Enterocytozoon bieneusi infection linked to transmission through food and water. } \\
\text { Encephalitozoon hellem keratoconjunctivitis possibly related to water or mud. Link to rainy } \\
\text { season in Singapore. }\end{array}$ & Weak & $\begin{array}{l}{[187,189,474-} \\
481]\end{array}$ & Waterborne & RSA [478] \\
\hline
\end{tabular}


Table A1. Cont.

\begin{tabular}{|c|c|c|c|c|c|}
\hline Pathogen & How Climate Might Affect Disease Occurrence & $\begin{array}{l}\text { Strength of } \\
\text { Evidence for } \\
\text { Water Related } \\
\text { Infections }\end{array}$ & $\begin{array}{l}\text { Human } \\
\text { Waterborne } \\
\text { Outbreaks or } \\
\text { Infections }\end{array}$ & $\begin{array}{l}\text { Type of } \\
\text { Infection } \\
\text { Route }\end{array}$ & $\begin{array}{l}\text { Study Linking } \\
\text { Weather/Climate } \\
\text { and Infection }\end{array}$ \\
\hline $\begin{array}{l}\text { Microsporidia- } \\
\text { Encephalitozoon } \\
\text { spp. }\end{array}$ & $\begin{array}{l}\text { E. intestinalis is a microsporidian (protozoan) parasite that is associated with diarrhoeal } \\
\text { disease in immunodeficient patients, particularly AIDS. Its transmissibility by food and } \\
\text { water is not known. E. cuniculi is associated with disseminated infection involving the } \\
\text { kidneys, sinuses, lungs, brain and conjunctiva in immunodeficient patients, particularly } \\
\text { AIDS. Its transmissibility by food and water is not known. E. hellem is associated with nasal } \\
\text { and ocular disease in immunodeficient patients, particularly AIDS. Its transmissibility by } \\
\text { food and water is not known. }\end{array}$ & Weak & $\mathrm{NE}$ & Unknown & $\mathrm{NE}$ \\
\hline $\begin{array}{l}\text { Microsporidia- } \\
\text { Enterocytozoon } \\
\text { bieneusi }\end{array}$ & $\begin{array}{l}\text { A parasite associated with diarrhoeal disease in immunodeficient patients, particularly AIDS. } \\
\text { Its transmissibility by food and water is not known. E. bieneusi is usually confined to the } \\
\text { intestines and is not associated with disseminated infection. E. bieneusi has been detected in } \\
\text { pigs, cats, dogs and a rhesus monkey. E. bieneusi is transmitted through the usual faecal-oral } \\
\text { pathways including food and water. Outbreaks have been linked to water and food. }\end{array}$ & Weak & {$[189,474]$} & Waterborne & $\mathrm{NE}$ \\
\hline $\begin{array}{l}\text { Mycobacterium spp. } \\
\text { (not TB) }\end{array}$ & Infections related to buildings and the built environment. & Strong & {$[275,482-492]$} & Waterborne & LR [493] \\
\hline $\begin{array}{l}\text { Mycobacterium } \\
\text { avium }\end{array}$ & $\begin{array}{l}\text { Contains three subspecies (M. avium subsp. avium, M. avium subsp. sylvaticum and M. avium } \\
\text { subsp. paratuberculosis). Organisms belonging to the Mycobacterium avium complex (MAC) } \\
\text { include M. avium, M. intracellulare and M. scrofulacium. They can cause intestinal infection, } \\
\text { septicaemia and wasting in AIDS patients, up to } 50 \% \text { of whom may develop MAC } \\
\text { bacteraemia. Where the isolates have been speciated they have been found to be } \\
\text { predominantly } M \text {. avium. Isolates recovered from water are probably a source of human } \\
\text { infection. Organisms of the MAC group are able to grow in both hot and cold-water systems. }\end{array}$ & Moderate & {$[275,494,495]$} & Waterborne & $\mathrm{NE}$ \\
\hline $\begin{array}{l}\text { Mycobacterium } \\
\text { paratuberculosis }\end{array}$ & $\begin{array}{l}\text { A slow-growing bacteria that causes Johne's disease in agricultural animals. It has been } \\
\text { implicated in the causation of Crohn's disease in humans. M. paratuberculosis (or M. avium } \\
\text { subsp. paratuberculosis (Map)) has been detected in water using PCR but has not to date been } \\
\text { isolated from potable water supplies. }\end{array}$ & Weak & $\mathrm{NE}$ & Unknown & $\mathrm{NE}$ \\
\hline Naegleria fowleri & $\begin{array}{l}\text { Colonises thermally polluted waters. Infections in Southern US are seasonal, with more in } \\
\text { the summer. Infections in cattle are also seasonal. Infections may increase in some countries } \\
\text { with warmer temperatures. Runoff from heavy rains introduces this organism into lakes, } \\
\text { ponds, and surface waters }[189,496] \text {. }\end{array}$ & $\begin{array}{l}\text { Strong, links to } \\
\text { water } \\
\text { contamination }\end{array}$ & {$[187,189,497]$} & Waterborne & SCS [498] \\
\hline Norovirus & $\begin{array}{l}\text { Is mostly transmitted person-to-person. Transmission has also been indicated via } \\
\text { contaminated ice, stored water on cruise ships, borehole water and contaminated recreational } \\
\text { bathing waters. Municipal drinking water supplies have been implicated in outbreaks of } \\
\text { gastroenteritis, usually following contamination by sewage. Strongly seasonal. Link to } \\
\text { shellfish contaminated from infected faeces. Coastal water contamination linked to rainfall. }\end{array}$ & Strong & {$[416,499-508]$} & Waterborne & OI [509] \\
\hline
\end{tabular}


Table A1. Cont.

\begin{tabular}{|c|c|c|c|c|c|}
\hline Pathogen & How Climate Might Affect Disease Occurrence & $\begin{array}{l}\text { Strength of } \\
\text { Evidence for } \\
\text { Water Related } \\
\text { Infections }\end{array}$ & $\begin{array}{l}\text { Human } \\
\text { Waterborne } \\
\text { Outbreaks or } \\
\text { Infections }\end{array}$ & $\begin{array}{l}\text { Type of } \\
\text { Infection } \\
\text { Route }\end{array}$ & $\begin{array}{l}\text { Study Linking } \\
\text { Weather/Climate } \\
\text { and Infection }\end{array}$ \\
\hline $\begin{array}{l}\text { Plesiomonas } \\
\text { shigelloides }\end{array}$ & $\begin{array}{l}\text { Plesiomonas shigelloides is a bacterial pathogen that has been implicated as a cause of } \\
\text { diarrhoeal disease. It is common in the natural waters in tropical countries. No well } \\
\text { documented waterborne outbreaks (two reported in 1978). No associations with rainfall or } \\
\text { temperature. }\end{array}$ & None & $\begin{array}{l}{[51,296,497} \\
510-513]\end{array}$ & Waterborne & $\mathrm{NE}$ \\
\hline $\begin{array}{l}\text { Pseudomonas } \\
\text { aeruginosa }\end{array}$ & $\begin{array}{l}\text { Contamination of natural and man-made bathing waters. Most folliculitis infections are } \\
\text { related to spa pools. Swimming in natural waters can cause otitis externa. No evidence of } \\
\text { rain or temperature link. }\end{array}$ & Strong & {$[497,514]$} & Waterborne & $\mathrm{NE}$ \\
\hline $\begin{array}{l}\text { Rhinosporidium } \\
\text { seeberi }\end{array}$ & $\begin{array}{l}\text { Infections linked to lake, river and well water in India. Outbreak linked to bathing in } \\
\text { stagnant water in Serbia. }\end{array}$ & Moderate & {$[515-518]$} & Waterborne & $\mathrm{NE}$ \\
\hline Rotavirus & $\begin{array}{l}\text { Rotavirus. Rotaviruses are part of the Reovirus family and have a double stranded RNA } \\
\text { genome. Exposure is by contact with infected individuals or contaminated water or other } \\
\text { materials. Group C rotaviruses have been identified throughout the world. Group B } \\
\text { rotaviruses have caused large outbreaks of diarrhoeal illness in mainland China. The virus } \\
\text { entered the population as a result of faecal contamination of water supplies drawn from } \\
\text { rivers, and then spread through the population by person-to-person contact. Waterborne } \\
\text { outbreaks in developing countries }\end{array}$ & Weak & {$[197,519-525]$} & Waterborne & [526] \\
\hline $\begin{array}{l}\text { Stenotrophomonas } \\
\text { maltophilia }\end{array}$ & Hospital outbreaks linked to contaminated water systems. & Moderate & {$[527-531]$} & Waterborne & $\mathrm{NE}$ \\
\hline Salmonella spp. & $\begin{array}{l}\text { Are strongly associated with foodborne disease but can also be transmitted through } \\
\text { waterborne and other routes. There is a particular problem with the occurrence of } \\
\text { Salmonellas in agricultural animals and the transmission to people through poor slaughter } \\
\text { hygiene and kitchen practices. This particularly results from their ability to grow within } \\
\text { foods to numbers that can cause disease. Outbreaks and sporadic disease related to } \\
\text { contaminated drinking water and recreational water. No clear links to rain. }\end{array}$ & Moderate & {$[518,532-545]$} & Waterborne & $\begin{array}{l}\text { GAMTS [546]; } \\
\text { GLM [546]; } \\
\text { EACWQ [547] }\end{array}$ \\
\hline $\begin{array}{l}\text { Salmonella } \\
\text { Paratyphi }\end{array}$ & $\begin{array}{l}\text { Causes paratyphoid fever. Infections can be acquired from travel overseas, and food and } \\
\text { waterborne infection can also occur. }\end{array}$ & Moderate & [548] & Waterborne & NE \\
\hline Salmonella Typhi & $\begin{array}{l}\text { Causes typhoid (fever and diarrhoea). The infectious dose is low, and large waterborne } \\
\text { outbreaks were common in the first half of the 20th century. Waterborne infection can arise } \\
\text { through sewage contamination of drinking water and through typhoid carriers who are } \\
\text { water workers. There is no natural animal host of this pathogen. Most infections are in } \\
\text { people returning from less developed countries. }\end{array}$ & Strong & {$[535,541,549]$} & Waterborne & RSA [550] \\
\hline Sappinia diploidea & A rare cause of amoebic cerebral abscess. & None & {$[551,552]$} & Waterborne & $\mathrm{NE}$ \\
\hline
\end{tabular}


Table A1. Cont.

\begin{tabular}{|c|c|c|c|c|c|}
\hline Pathogen & How Climate Might Affect Disease Occurrence & $\begin{array}{l}\text { Strength of } \\
\text { Evidence for } \\
\text { Water Related } \\
\text { Infections }\end{array}$ & $\begin{array}{l}\text { Human } \\
\text { Waterborne } \\
\text { Outbreaks or } \\
\text { Infections }\end{array}$ & $\begin{array}{l}\text { Type of } \\
\text { Infection } \\
\text { Route }\end{array}$ & $\begin{array}{l}\text { Study Linking } \\
\text { Weather/Climate } \\
\text { and Infection }\end{array}$ \\
\hline Sapovirus & $\begin{array}{l}\text { A calicivirus, formerly called "Sapporo-like virus" (SLV), classic or typical calicivirus and are } \\
\text { associated with relatively mild gastroenteritis in children. Outbreak linked to flood water } \\
\text { contamination of shellfish with several viruses. }\end{array}$ & Weak & [183] & & POWE [213] \\
\hline Sarcocystis hominis & Sporocysts are infectious, causing muscle infections through drinking water. & Strong & {$[553,554]$} & Waterborne & NE \\
\hline Schistosoma spp. & $\begin{array}{l}\text { These are flukes (helminth) which are transmitted through the contamination of water with } \\
\text { faeces containing the ova. Cases linked to flooding and land surface temperature. }\end{array}$ & Strong & [555] & Water based & $\begin{array}{l}\text { OI [556]; SA } \\
\text { [557-560]; RRM } \\
\text { [561]; MM [562]; } \\
\text { MLM [563] }\end{array}$ \\
\hline $\begin{array}{l}\text { Schistosoma } \\
\text { intercalatum }\end{array}$ & $\begin{array}{l}\text { The life cycle involves the ova hatching and infecting specific snail species, and the cercaria } \\
\text { infect people occupationally or recreationally exposed to contaminated water through the } \\
\text { skin. }\end{array}$ & Strong & [564] & Water based & $\mathrm{NE}$ \\
\hline $\begin{array}{l}\text { Schistosoma } \\
\text { haematobium }\end{array}$ & $\begin{array}{l}\text { The life cycle involves the ova hatching and infecting specific snail species, and the cercaria } \\
\text { infect people occupationally or recreationally exposed to contaminated water through the } \\
\text { skin. Infection is found in Africa and the Middle East. }\end{array}$ & Strong & {$[564,565]$} & Water based & $\mathrm{NE}$ \\
\hline $\begin{array}{l}\text { Schistosoma } \\
\text { japonicum }\end{array}$ & $\begin{array}{l}\text { Infection is found in Eastern Asia including Japan and Korea. Links to rainfall and } \\
\text { temperature. }\end{array}$ & Strong & [566] & Water based & CSS [563] \\
\hline $\begin{array}{l}\text { Schistosoma } \\
\text { mansoni }\end{array}$ & $\begin{array}{l}\text { The life cycle involves the ova hatching and infecting specific snail species, and the cercaria } \\
\text { infect people occupationally or recreationally exposed to contaminated water through the } \\
\text { skin. }\end{array}$ & Strong & {$[564,567-570]$} & Water based & OI [556]; SA [560] \\
\hline $\begin{array}{l}\text { Schistosoma } \\
\text { mekongi }\end{array}$ & $\begin{array}{l}\text { The life cycle involves the ova hatching and infecting specific snail species, and the cercaria } \\
\text { infect people occupationally or recreationally exposed to contaminated water (usually river } \\
\text { water) through the skin. Infection is restricted to South East Asia, particularly the Mekong } \\
\text { River basin in Kampuchea. }\end{array}$ & Strong & [571-574] & Water based & $\mathrm{NE}$ \\
\hline $\begin{array}{l}\text { Schistosoma } \\
\text { spindale }\end{array}$ & $\begin{array}{l}\text { A fluke (helminth) that commonly causes cercarial dermatitis of paddy field workers in } \\
\text { Assam, India. It is unclear which species of animal the schistosomes derive from although } \\
\text { ducks are likely. }\end{array}$ & Strong & [575] & Water based & $\mathrm{NE}$ \\
\hline Spirometra spp. & $\begin{array}{l}\text { These are tapeworms (helminth) and occur in amphibious animals including frogs. Ingestion } \\
\text { of the first stage larvae which are present in the copepod Cyclops results in human } \\
\text { sparganosis, with 'Sparganum' larvae forming in nodules. Infection is thought to derive from } \\
\text { contaminated drinking water or the consumption of uncooked frogs or snakes. S. } \\
\text { mansonoides (S. erinacei-europaei) is the organism most commonly diagnosed. }\end{array}$ & Weak & [576-579] & Waterborne & $\mathrm{NE}$ \\
\hline
\end{tabular}


Table A1. Cont.

\begin{tabular}{|c|c|c|c|c|c|}
\hline Pathogen & How Climate Might Affect Disease Occurrence & $\begin{array}{l}\text { Strength of } \\
\text { Evidence for } \\
\text { Water Related } \\
\text { Infections }\end{array}$ & $\begin{array}{l}\text { Human } \\
\text { Waterborne } \\
\text { Outbreaks or } \\
\text { Infections }\end{array}$ & $\begin{array}{l}\text { Type of } \\
\text { Infection } \\
\text { Route }\end{array}$ & $\begin{array}{l}\text { Study Linking } \\
\text { Weather/Climate } \\
\text { and Infection }\end{array}$ \\
\hline Shigella spp. & $\begin{array}{l}\text { Causes dysentery and can be readily passed between children and adults in unsanitary } \\
\text { environments. They can occasionally be transmitted through contaminated food. Waterborne } \\
\text { outbreaks of shigellosis have been common in the past, but are now uncommon and are } \\
\text { usually the result of a combination of inadequate treatment, post treatment contamination } \\
\text { and chlorination breakdown. Shigella spp. will not grow within water distribution systems. } \\
\text { There are four species. Shigella sonnei is commonly transmitted between children and can be a } \\
\text { problem in schools in the UK. Shigella dysenteriae is a more severe infection than S. sonnei and } \\
\text { causes severe dysentery. Most S. boydii, S. flexneri and S. dysenteriae infections within England } \\
\text { and Wales are usually acquired abroad. Lake water recreational outbreaks. }\end{array}$ & Strong & {$[355,580-584]$} & Waterborne & OI [284] \\
\hline Torovirus & $\begin{array}{l}\text { Toroviruses are enveloped viruses that have been linked to enteric infections in horses (Berne } \\
\text { virus), cattle (Breda virus), pigs, and humans and transmission is thought to be via the } \\
\text { faecal-oral route. In humans toroviruses have been found in infants with necrotising } \\
\text { enterocolitis but their role in gastroenteritis remains unproved. }\end{array}$ & Weak & $\mathrm{NE}$ & Unknown & $\mathrm{NE}$ \\
\hline Toxoplasma gondii & $\begin{array}{l}\text { A protozoan parasite which occurs in a wide range of warm-blooded animals. The only } \\
\text { definitive host in which the full sexual cycle has been observed is members of the cat family } \\
\text { (Felidae), which excrete the oocysts which contaminate the environment and source waters. } \\
\text { People can be infected from consuming food or water that is contaminated with oocysts or } \\
\text { the consumption of undercooked meat which contains tissue cysts. Infection can be a } \\
\text { particular problem for pregnant women and immunocompromised patients. Some evidence } \\
\text { that heavy rainfall can precede outbreaks. }\end{array}$ & Strong & $\begin{array}{l}{[187,190,585-} \\
589]\end{array}$ & Waterborne & OI [590]; SA [591]; \\
\hline $\begin{array}{l}\text { Trichobilharzia } \\
\text { regent }\end{array}$ & $\begin{array}{l}\text { A schistosome of birds and the cercaria can give rise to an itchy rash (known as cercarial } \\
\text { dermatitis or swimmer's itch) in people who have had contact with the water. They are } \\
\text { otherwise thought to be non-pathogenic to humans. The parasites mature and lay eggs in the } \\
\text { nasal cavities of waterfowl. The lifecycle involves snails. }\end{array}$ & Strong & [592-599] & Water based & $\mathrm{NE}$ \\
\hline Vibrio cholerae & $\begin{array}{l}\text { Causes cholera, a disease that is characterised by acute and life-threatening diarrhoea and } \\
\text { dehydration usually in epidemic outbreaks. Cholera is transmitted through drinking water, } \\
\text { shellfish and contaminated food. The disease is usually restricted to less developed countries } \\
\text { where drinking water and waste disposal are poor, and to migrant populations associated } \\
\text { with drought, flood, famine and war. Evidence of links to rainfall over the last century. }\end{array}$ & Strong & {$[600-602]$} & Waterborne & $\begin{array}{l}\text { [603,604]; GAMTS } \\
\text { [605]; [606]; EACO } \\
\text { [607]; POWE [608] }\end{array}$ \\
\hline $\begin{array}{l}\text { Vibrio } \\
\text { parahaemolyticus }\end{array}$ & $\begin{array}{l}\text { Inhabits estuarine and marine environments. It can cause food-poisoning through the } \\
\text { contamination of seafood. V. parahaemolyticus associated with raised water temperature. }\end{array}$ & Moderate & [609] & $\begin{array}{l}\text { Foodborne } \\
\text { through } \\
\text { seafood }\end{array}$ & RSE [610] \\
\hline
\end{tabular}


Table A1. Cont.

\begin{tabular}{|c|c|c|c|c|c|}
\hline Pathogen & How Climate Might Affect Disease Occurrence & $\begin{array}{l}\text { Strength of } \\
\text { Evidence for } \\
\text { Water Related } \\
\text { Infections }\end{array}$ & $\begin{array}{l}\text { Human } \\
\text { Waterborne } \\
\text { Outbreaks or } \\
\text { Infections }\end{array}$ & $\begin{array}{l}\text { Type of } \\
\text { Infection } \\
\text { Route }\end{array}$ & $\begin{array}{l}\text { Study Linking } \\
\text { Weather/Climate } \\
\text { and Infection }\end{array}$ \\
\hline Vibrio vulnificus & $\begin{array}{l}\text { Vibrio vulnificus can cause severe, soft tissue infections, septicaemia, and deaths. Infection is } \\
\text { through the consumption of contaminated seafood (particularly raw oysters). V. vulnificus } \\
\text { infection increased following hurricane Katrina. }\end{array}$ & Strong & {$[609,611,612]$} & $\begin{array}{l}\text { Waterborne; } \\
\text { Foodborne } \\
\text { through } \\
\text { seafood }\end{array}$ & $\begin{array}{l}\text { MMF [613]; HSM } \\
\text { [614]; MMST [615]; } \\
\text { OI [611] }\end{array}$ \\
\hline $\begin{array}{l}\text { Vibrio spp. (other } \\
\text { than V. cholerae) }\end{array}$ & $\begin{array}{l}\text { A variety of Vibrio spp. can cause human disease, including the halophilic } V \text {. } \\
\text { parahaemolyticus, } V \text {. fluvialis, } V \text {. hollisae and the non-halophilic vibrios non-O1 } V \text {. cholerae and } \\
V \text {. mimicus. Cholera is a classical waterborne disease, and the water route is still important in } \\
\text { developing countries. There is no evidence that vibrios are able to cause human disease by } \\
\text { growing within water distribution systems. Vibrio spp. are part of normal marine flora and } \\
\text { can be found in marine, estuarine and river water. These organisms and proliferate during } \\
\text { the summer months. People are infected through the consumption of raw or undercooked } \\
\text { contaminated shellfish, other foods and faecally contaminated water. A large infective dose } \\
\text { is required to initiate infection and person-to-person transmission does not occur. Infections } \\
\text { in the United Kingdom tend to be in travellers returning from developing countries. } \\
\text { Non-cholera } V \text {. cholera in warmer Baltic waters. }\end{array}$ & Strong & {$[36,609]$} & Waterborne & $\begin{array}{l}\mathrm{MMO}=[616] ; \mathrm{OI} \\
\text { [617]; TSAT [611]; } \\
\text { WMR [615]; POTA } \\
\text { [617] }\end{array}$ \\
\hline Yersinia spp. & $\begin{array}{l}\text { Yersinia spp. are bacteria that can cause diarrhoea, arthritis and mesenteric lymphadenitis, } \\
\text { and small waterborne outbreaks of infection can occur. Infection usually derives from an } \\
\text { animal source, particularly pigs. Non-pathogenic types can be detected in people and are not } \\
\text { thought to be involved as a cause of diarrhoea. Y.pseudotuberculosis causes fever, } \\
\text { enlargement of the mesenteric lymph nodes, pseudo-appendicitis, septicaemia and diarrhoea. } \\
\text { Yersinia enterocolitica can cause diarrhoea, arthritis and mesenteric lymphadenitis, and small } \\
\text { waterborne outbreaks of infection can occur. Y. fredriksenii and Y. kristensenii have been } \\
\text { isolated from the faecal samples of people with diarrhoea, but their pathogenic role is unclear. }\end{array}$ & Moderate & [618-620] & Waterborne & NE \\
\hline Mixed causes & $\begin{array}{l}\text { Climate change and waterborne illness [180,181] } \\
\text { Relationship between recreational water outbreaks and temperature [54]. } \\
\text { Review of waterborne outbreaks [621] }\end{array}$ & $\mathrm{NE}$ & $\begin{array}{l}{[187,190,257,} \\
258]\end{array}$ & Mixed & $\begin{array}{l}\text { ROS [36,622]; FTA } \\
{[293] ; \text { RCCS }} \\
{[32,269] ; \text { QMRA }} \\
{[374,623]}\end{array}$ \\
\hline
\end{tabular}




\section{References}

1. IPCC. Climate Change 2013: The Physical Science Basis. In Contribution of Working Group I to the Fifth Assessment Report of the Intergovernmental Panel on Climate Change; Stocker, T.F.Q.D., Plattner, G.K., Tignor, M., Allen, S.K., Boschung, J., Nauels, A., Xia, Y., Bex, V., Midgley, P.M., Eds.; Cambridge University Press: Cambridge, UK; New York, NY, USA, 2013; pp. 1-1535.

2. IPCC. Managing the Risks of Extreme Events and Disasters to Advance Climate Change Adaptation. In $A$ Special Report of Working Groups I and II of the Intergovernmental Panel on Climate Change; Field, C.B.B.V., Stocker, T.F., Qin, D., Dokken, D.J., Ebi, K.L., Mastrandrea, M.D., Mach, K.J., Plattner, G.K., Allen, S.K., Tignor, M., et al., Eds.; Cambridge University Press: Cambridge, UK; New York, NY, USA, 2012; pp. 1-582.

3. Hardin, G. The tragedy of the commons. The population problem has no technical solution; it requires a fundamental extension in morality. Science 1968, 162, 1243-1248. [PubMed]

4. Patz, J.A.; Campbell-Lendrum, D.; Holloway, T.; Foley, J.A. Impact of regional climate change on human health. Nature 2005, 438, 310-317. [CrossRef] [PubMed]

5. Stern, N. Stern Review: The Economics of Climate Change; Edward Elgar Publishing: Cheltenham, UK, 2008.

6. Gasparrini, A.; Guo, Y.; Sera, F.; Vicedo-Cabrera, A.M.; Huber, V.; Tong, S.; de Sousa Zanotti Stagliorio Coelho, M.; Nascimento Saldiva, P.H.; Lavigne, E.; Matus Correa, P.; et al. Projections of temperature-related excess mortality under climate change scenarios. Lancet Planet Health 2017, 1, e360-e367. [CrossRef]

7. Melorose, J.P.R.; Careas, S. World Population Prospects; United Nations: New York, NY, USA, 2015; pp. $587-592$.

8. McMichael, A.J.; Wilcox, B.A. Climate change, human health, and integrative research: A transformative imperative. EcoHealth 2009, 6, 163-164. [CrossRef] [PubMed]

9. Hsiang, S.M.; Burke, M.; Miguel, E. Quantifying the influence of climate on human conflict. Science 2013, 341, 1235367. [CrossRef] [PubMed]

10. Hsiang, S.M.; Meng, K.C.; Cane, M.A. Civil conflicts are associated with the global climate. Nature 2011, 476, 438-441. [CrossRef] [PubMed]

11. Dangendorf, F.; Herbst, S.; Reintjes, R.; Kistemann, T. Spatial patterns of diarrhoeal illnesses with regard to water supply structures-A GIS analysis. Int. J. Hyg. Environ. Health 2002, 205, 183-191. [CrossRef] [PubMed]

12. Schuur, E.A.; McGuire, A.D.; Schadel, C.; Grosse, G.; Harden, J.W.; Hayes, D.J.; Hugelius, G.; Koven, C.D.; Kuhry, P.; Lawrence, D.M.; et al. Climate change and the permafrost carbon feedback. Nature 2015, 520, 171-179. [CrossRef] [PubMed]

13. McMichael, A.J.; Woodward, A.; Muir, C. Climate Change and the Health of Nations: Famines, Fevers, and the Fate of Populations; Oxford University Press: New York, NY, USA, 2017; 370p.

14. Patz, J.A.; Grabow, M.L.; Limaye, V.S. When it rains, it pours: Future climate extremes and health. Ann. Glob. Health 2014, 80, 332-344. [CrossRef] [PubMed]

15. Raper, S.C.; Braithwaite, R.J. Low sea level rise projections from mountain glaciers and icecaps under global warming. Nature 2006, 439, 311-313. [CrossRef] [PubMed]

16. Jevrejeva, S.; Jackson, L.P.; Riva, R.E.; Grinsted, A.; Moore, J.C. Coastal sea level rise with warming above 2 degrees C. Proc. Natl. Acad. Sci. USA 2016, 113, 13342-13347. [CrossRef] [PubMed]

17. Koven, C.D.; Schuur, E.A.; Schadel, C.; Bohn, T.J.; Burke, E.J.; Chen, G.; Chen, X.; Ciais, P.; Grosse, G.; Harden, J.W.; et al. A simplified, data-constrained approach to estimate the permafrost carbon-climate feedback. Philos. Trans. Ser. A Math. Phys. Eng. Sci. 2015, 373. [CrossRef] [PubMed]

18. Orth, R.; Zscheischler, J.; Seneviratne, S.I. Record dry summer in 2015 challenges precipitation projections in Central Europe. Sci. Rep. 2016, 6, 28334. [CrossRef] [PubMed]

19. Steffen, W.; Rockström, J.; Richardson, K.; Lenton, T.M.; Folke, C.; Liverman, D.; Summerhayes, C.P.; Barnosky, A.D.; Cornell, S.E.; Crucifix, M.; et al. Trajectories of the Earth System in the Anthropocene. Proc. Natl. Acad. Sci. USA 2018, 115, 8252-8259. [CrossRef] [PubMed]

20. Michalak, A.M. Study role of climate change in extreme threats to water quality. Nature 2016, 535, 349-350. [CrossRef] [PubMed]

21. Sterk, A.; de Man, H.; Schijven, J.F.; de Nijs, T.; de Roda Husman, A.M. Climate change impact on infection risks during bathing downstream of sewage emissions from CSOs or WWTPs. Water Res. 2016, 105, 11-21. [CrossRef] [PubMed] 
22. Jiménez Cisneros, B.E.O.T.; Arnell, N.W.; Benito, G.; Cogley, J.G.; Döll, P.; Jiang, T.; Mwakalila, S.S. Freshwater Resources; Cambridge University Press: Cambridge, UK; New York, NY, USA, 2014; pp. 229-269.

23. Stathakou, N.P.; Stathakou, G.P.; Damianaki, S.G.; Ioannou, E.T.; Stavrianeas, N.G. Empedocles' bio-medical Comments: A Precursor of Modern Science. Available online: https://www.google.com/ search? client $=$ safari\&rls $=$ en\& $q=$ N.P. + Stathakou,MD, + G.P. + Stathakou,MD, + S.G. + Damianaki,MD,,+ E . +Toumbis+Ioannou,MD+and+N.G.+Stavrianeas,MD+Empedocles $\%$ E2\%80\%99+bio-medical+comments: $+\mathrm{A}+$ precursor + of + modern + science + Copyright $+\%$ C2\%A9+Priory + Lodge + Education + Limited $+2007 \&$ \&ie $=$ UTF-8\&oe=UTF-8 (accessed on 19 September 2018).

24. White, G.B.D.; White, A. Drawers of Water; University of Chicago Press: Chicago, IL, USA, 1972.

25. Bartram, J.H.P. Bradley Classification of disease transmission routes for water-related hazards. In Routledge Handbook of Water and Health; Bartram, J.B.R., Coclanis, P.A., Gute, D.M., Kay, D., Pond, K., Robertson, W., Rouse, M.J., Eds.; Routledge: London, UK; New York, NY, USA, 2015; pp. 20-37.

26. Nichols, G.L.; Mølbak, K. The sources and environmental origins of gastrointestinal pathogens. In Environmental Medicine; Ayres, J.G.H., Nichols, G.L., Maynard, R.L., Eds.; Hodder Arnold: London, UK, 2010; pp. 359-372.

27. Sobsey, M.D. Waterborne and water-washed disease. In Routledge Handbook of Water and Health; Bartram, J.B.R., Coclanis, P.A., Gute, D.M., Kay, D., Pond, K., Robertson, W., Rouse, M.J., Eds.; Routledge: London, UK; New York, NY, USA, 2015; pp. 38-50.

28. Guzman-Herrador, B.; Carlander, A.; Ethelberg, S.; Freiesleben de Blasio, B.; Kuusi, M.; Lund, V.; Lofdahl, M.; MacDonald, E.; Nichols, G.; Schonning, C.; et al. Waterborne outbreaks in the Nordic countries, 1998 to 2012. Euro Surveill. 2015, 20, 21160. [CrossRef] [PubMed]

29. Richardson, H.Y.; Nichols, G.; Lane, C.; Lake, I.R.; Hunter, P.R. Microbiological surveillance of private water supplies in England: The impact of environmental and climate factors on water quality. Water Res. 2009, 43, 2159-2168. [CrossRef] [PubMed]

30. Semenza, J.C.; Nichols, G. Cryptosporidiosis surveillance and water-borne outbreaks in Europe. Euro Surveill. 2007, 12, E13-E14. [CrossRef] [PubMed]

31. Smith, A.; Reacher, M.; Smerdon, W.; Adak, G.K.; Nichols, G.; Chalmers, R.M. Outbreaks of waterborne infectious intestinal disease in England and Wales, 1992-2003. Epidemiol. Infect. 2006, 134, 1141-1149. [CrossRef] [PubMed]

32. Nichols, G.; Lane, C.; Asgari, N.; Verlander, N.Q.; Charlett, A. Rainfall and outbreaks of drinking water related disease and in England and Wales. J. Water Health 2009, 7, 1-8. [CrossRef] [PubMed]

33. Said, B.; Wright, F.; Nichols, G.L.; Reacher, M.; Rutter, M. Outbreaks of infectious disease associated with private drinking water supplies in England and Wales 1970-2000. Epidemiol. Infect. 2003, 130, 469-479. [PubMed]

34. Rutter, M.; Nichols, G.L.; Swan, A.; De Louvois, J. A survey of the microbiological quality of private water supplies in England. Epidemiol. Infect. 2000, 124, 417-425. [CrossRef] [PubMed]

35. Rooney, R.M.; Bartram, J.K.; Cramer, E.H.; Mantha, S.; Nichols, G.; Suraj, R.; Todd, E.C. A review of outbreaks of waterborne disease associated with ships: Evidence for risk management. Public Health Rep. 2004, 119, 435-442. [CrossRef] [PubMed]

36. Cann, K.F.; Thomas, D.R.; Salmon, R.L.; Wyn-Jones, A.P.; Kay, D. Extreme water-related weather events and waterborne disease. Epidemiol. Infect. 2013, 141, 671-686. [CrossRef] [PubMed]

37. Levy, K.; Woster, A.P.; Goldstein, R.S.; Carlton, E.J. Untangling the Impacts of Climate Change on Waterborne Diseases: A Systematic Review of Relationships between Diarrheal Diseases and Temperature, Rainfall, Flooding, and Drought. Environ. Sci. Technol. 2016, 50, 4905-4922. [CrossRef] [PubMed]

38. Funari, E.; Manganelli, M.; Sinisi, L. Impact of climate change on waterborne diseases. Ann. dell'Istituto Super. Sanita 2012, 48, 473-487. [CrossRef]

39. Dale, K.; Kirk, M.; Sinclair, M.; Hall, R.; Leder, K. Reported waterborne outbreaks of gastrointestinal disease in Australia are predominantly associated with recreational exposure. Aust. N. Z. J. Public Health 2010, 34, 527-530. [CrossRef] [PubMed]

40. Nicole, W. The WASH approach: Fighting waterborne diseases in emergency situations. Environ. Health Perspect. 2015, 123, A6-A15. [CrossRef] [PubMed]

41. Lim, J.H.; Yoon, D.; Jung, G.; Joo Kim, W.; Lee, H.C. Medical needs of tsunami disaster refugee camps. Fam. Med. 2005, 37, 422-428. [PubMed] 
42. Nichols, G. Water supply, Waterborne infection and sewage/sludge disposal. In Hobbs's Food Poisoning and Food Hygiene; McLauchlin, J.L.C., Ed.; Hodder Arnold: London, UK, 2007; pp. 146-165.

43. Burton, F.L.; Tchobanoglous, G.; Tsuchihashi, R.; Stensel, H.D. Wastewater Engineering: Treatment and Reuse; McGraw-Hill Education: Columbus, OH, USA, 2003; p. 1819.

44. Schwartz, J.; Levin, R.; Goldstein, R. Drinking water turbidity and gastrointestinal illness in the elderly of Philadelphia. J. Epidemiol. Community Health 2000, 54, 45-51. [CrossRef] [PubMed]

45. Lake, I.R.; Bentham, G.; Kovats, R.S.; Nichols, G.L. Effects of weather and river flow on cryptosporidiosis. J. Water Health 2005, 3, 469-474. [CrossRef] [PubMed]

46. Delpla, I.; Jung, A.V.; Baures, E.; Clement, M.; Thomas, O. Impacts of climate change on surface water quality in relation to drinking water production. Environ. Int. 2009, 35, 1225-1233. [CrossRef] [PubMed]

47. Jiang, Y.S.; Riedel, T.E.; Popoola, J.A.; Morrow, B.R.; Cai, S.; Ellington, A.D.; Bhadra, S. Portable platform for rapid in-field identification of human fecal pollution in water. Water Res. 2017, 131, 186-195. [CrossRef] [PubMed]

48. Voisin, H.; Bergstrom, L.; Liu, P.; Mathew, A.P. Nanocellulose-Based Materials for Water Purification. Nanomaterials 2017, 7, E57. [CrossRef] [PubMed]

49. McPhail, C.D.; Stidson, R.T. Aquatic Bathing water signage and predictive water quality models in Scotland. Ecosyst. Health Manag. 2009, 12, 183-186. [CrossRef]

50. Whiley, H.; Bentham, R.; Brown, M.H. Legionella Persistence in Manufactured Water Systems: Pasteurization Potentially Selecting for Thermal Tolerance. Front. Microbiol. 2017, 8, 1330. [CrossRef] [PubMed]

51. Craun, G.F.; Calderon, R.L.; Craun, M.F. Outbreaks associated with recreational water in the United States. Int. J. Environ. Health Res. 2005, 15, 243-262. [CrossRef] [PubMed]

52. Soldanova, M.; Selbach, C.; Kalbe, M.; Kostadinova, A.; Sures, B. Swimmer's itch: Etiology, impact, and risk factors in Europe. Trends Parasitol. 2013, 29, 65-74. [CrossRef] [PubMed]

53. Xu, J.F.; Xu, J.; Li, S.Z.; Jia, T.W.; Huang, X.B.; Zhang, H.M.; Chen, M.; Yang, G.J.; Gao, S.J.; Wang, Q.Y.; et al. Transmission risks of schistosomiasis japonica: Extraction from back-propagation artificial neural network and logistic regression model. PLoS Negl. Trop. Dis. 2013, 7, e2123. [CrossRef] [PubMed]

54. Schets, F.M.; De Roda Husman, A.M.; Havelaar, A.H. Disease outbreaks associated with untreated recreational water use. Epidemiol. Infect. 2011, 139, 1114-1125. [CrossRef] [PubMed]

55. Roser, D.J.; van den Akker, B.; Boase, S.; Haas, C.N.; Ashbolt, N.J.; Rice, S.A. Pseudomonas aeruginosa dose response and bathing water infection. Epidemiol. Infect. 2014, 142, 449-462. [CrossRef] [PubMed]

56. Redbord, K.P.; Shearer, D.A.; Gloster, H.; Younger, B.; Connelly, B.L.; Kindel, S.E.; Lucky, A.W. Atypical Mycobacterium furunculosis occurring after pedicures. J. Am. Acad. Dermatol. 2006, 54, 520-524. [CrossRef] [PubMed]

57. Fiorillo, L.; Zucker, M.; Sawyer, D.; Lin, A.N. The pseudomonas hot-foot syndrome. N. Engl. J. Med. 2001, 345, 335-338. [CrossRef] [PubMed]

58. Julia Manresa, M.; Vicente Villa, A.; Gene Giralt, A.; Gonzalez-Ensenat, M.A. Aeromonas hydrophila folliculitis associated with an inflatable swimming pool: Mimicking Pseudomonas aeruginosa infection. Pediatr. Dermatol. 2009, 26, 601-603. [CrossRef] [PubMed]

59. Gauthier, J.; Gerome, P.; Defez, M.; Neulat-Ripoll, F.; Foucher, B.; Vitry, T.; Crevon, L.; Valade, E.; Thibault, F.M.; Biot, F.V. Melioidosis in Travelers Returning from Vietnam to France. Emerg. Infect. Dis. 2016, 22, 1671-1673. [CrossRef] [PubMed]

60. Jones, E.H.; Feldman, K.A.; Palmer, A.; Butler, E.; Blythe, D.; Mitchell, C.S. Vibrio infections and surveillance in Maryland, 2002-2008. Public Health Rep. 2013, 128, 537-545. [CrossRef] [PubMed]

61. Ozluer, S.M.; De'Ambrosis, B.J. Mycobacterium abscessus wound infection. Australas. J. Dermatol. 2001, 42, 26-29. [CrossRef] [PubMed]

62. Merritt, A.J.; Peck, M.; Gayle, D.; Levy, A.; Ler, Y.H.; Raby, E.; Gibbs, T.M.; Inglis, T.J. Cutaneous Melioidosis Cluster Caused by Contaminated Wound Irrigation Fluid. Emerg. Infect. Dis. 2016, 22. [CrossRef] [PubMed]

63. Trautmann, M.; Halder, S.; Lepper, P.M.; Exner, M. Reservoirs of Pseudomonas aeruginosa in the intensive care unit. The role of tap water as a source of infection. Bundesgesundheitsblatt Gesundheitsforschung Gesundheitsschutz 2009, 52, 339-344. [CrossRef] [PubMed]

64. Cohen, R.; Babushkin, F.; Shimoni, Z.; Cohen, S.; Litig, E.; Shapiro, M.; Adler, A.; Paikin, S. Water faucets as a source of Pseudomonas aeruginosa infection and colonization in neonatal and adult intensive care unit patients. Am. J. Infect. Control 2017, 45, 206-209. [CrossRef] [PubMed] 
65. Walker, J.T.; Jhutty, A.; Parks, S.; Willis, C.; Copley, V.; Turton, J.F.; Hoffman, P.N.; Bennett, A.M. Investigation of healthcare-acquired infections associated with Pseudomonas aeruginosa biofilms in taps in neonatal units in Northern Ireland. J. Hosp. Infect. 2014, 86, 16-23. [CrossRef] [PubMed]

66. Jefferies, J.M.; Cooper, T.; Yam, T.; Clarke, S.C. Pseudomonas aeruginosa outbreaks in the neonatal intensive care unit-A systematic review of risk factors and environmental sources. J. Med. Microbiol. 2012, 61, 1052-1061. [CrossRef] [PubMed]

67. Maloney, S.; Welbel, S.; Daves, B.; Adams, K.; Becker, S.; Bland, L.; Arduino, M.; Wallace, R., Jr.; Zhang, Y.; Buck, G.; et al. Mycobacterium abscessus pseudoinfection traced to an automated endoscope washer: Utility of epidemiologic and laboratory investigation. J. Infect. Dis. 1994, 169, 1166-1169. [CrossRef] [PubMed]

68. Al-Assaf, N.; Moore, H.; Leifso, K.; Ben Fadel, N.; Ferretti, E. Disseminated Neonatal Herpes Simplex Virus Type 1 After a Water Birth. J. Pediatr. Infect. Dis. Soc. 2017, 6, e169-e172. [CrossRef] [PubMed]

69. Fritschel, E.; Sanyal, K.; Threadgill, H.; Cervantes, D. Fatal legionellosis after water birth, Texas, USA, 2014. Emerg. Infect. Dis. 2015, 21, 130-132. [CrossRef] [PubMed]

70. Soileau, S.L.; Schneider, E.; Erdman, D.D.; Lu, X.; Ryan, W.D.; McAdams, R.M. Case report: Severe disseminated adenovirus infection in a neonate following water birth delivery. J. Med. Virol. 2013, 85, 667-669. [CrossRef] [PubMed]

71. Franzin, L.; Cabodi, D.; Scolfaro, C.; Gioannini, P. Microbiological investigations on a nosocomial case of Legionella pneumophila pneumonia associated with water birth and review of neonatal cases. InfezMed 2004, 12, 69-75.

72. Berendes, D.; Levy, K.; Knee, J.; Handzel, T.; Hill, V.R. Ascaris and Escherichia coli Inactivation in an Ecological Sanitation System in Port-au-Prince, Haiti. PLoS ONE 2015, 10, e0125336. [CrossRef] [PubMed]

73. McKerr, C.; Adak, G.K.; Nichols, G.; Gorton, R.; Chalmers, R.M.; Kafatos, G.; Cosford, P.; Charlett, A.; Reacher, M.; Pollock, K.G.; et al. An Outbreak of Cryptosporidium parvum across England \& Scotland Associated with Consumption of Fresh Pre-Cut Salad Leaves, May 2012. PLoS ONE 2015, 10, e0125955. [CrossRef]

74. Nichols, G.L.; Freedman, J.; Pollock, K.G.; Rumble, C.; Chalmers, R.M.; Chiodini, P.; Hawkins, G.; Alexander, C.L.; Godbole, G.; Williams, C.; et al. Cyclospora infection linked to travel to Mexico, June to September 2015. Euro Surveill. 2015, 20. [CrossRef] [PubMed]

75. Nichols, G.L. Human health risks from toxic cyanobacteria, dinoflagellates and diatoms. In Environmental Medicine; Ayers, J., Harrison, R., Maynard, R., Nichols, G.L., Eds.; Hodder Arnold: London, UK, 2010.

76. Dance, D.A. Melioidosis. Curr. Opin. Infect. Dis. 2002, 15, 127-132. [CrossRef] [PubMed]

77. Ogden, N.H. Climate change and vector-borne diseases of public health significance. FEMS Microbiol. Lett. 2017, 364. [CrossRef] [PubMed]

78. Bouzid, M.; Hooper, L.; Hunter, P.R. The effectiveness of public health interventions to reduce the health impact of climate change: A systematic review of systematic reviews. PLoS ONE 2013, 8, e62041. [CrossRef] [PubMed]

79. Sargeant, J.M.; Amezcua, M.R.; Rajic, A.; Waddell, L. Pre-harvest interventions to reduce the shedding of $E$. coli $\mathrm{O} 157$ in the faeces of weaned domestic ruminants: A systematic review. Zoonoses Public Health 2007, 54, 260-277. [CrossRef] [PubMed]

80. Kostyla, C.; Bain, R.; Cronk, R.; Bartram, J. Seasonal variation of fecal contamination in drinking water sources in developing countries: A systematic review. Sci. Total Environ. 2015, 514, 333-343. [CrossRef] [PubMed]

81. Doocy, S.; Daniels, A.; Murray, S.; Kirsch, T.D. The human impact of floods: A historical review of events 1980-2009 and systematic literature review. PLoS Curr. 2013, 5. [CrossRef] [PubMed]

82. Doocy, S.; Daniels, A.; Dick, A.; Kirsch, T.D. The human impact of tsunamis: A historical review of events 1900-2009 and systematic literature review. PLoS Curr. 2013, 5. [CrossRef] [PubMed]

83. Barbier, E.B. Policy: Hurricane Katrina's lessons for the world. Nature 2015, 524, 285-287. [CrossRef] [PubMed]

84. Yee, E.L.; Palacio, H.; Atmar, R.L.; Shah, U.; Kilborn, C.; Faul, M.; Gavagan, T.E.; Feigin, R.D.; Versalovic, J.; Neill, F.H.; et al. Widespread outbreak of norovirus gastroenteritis among evacuees of Hurricane Katrina residing in a large "megashelter" in Houston, Texas: Lessons learned for prevention. Clin. Infect. Dis. 2007, 44, 1032-1039. [CrossRef] [PubMed] 
85. CDC. Vibrio illnesses after Hurricane Katrina-Multiple states, August-September 2005. MMWR Morb. Mortal. Wkly. Rep. 2005, 54, 928-931.

86. Brown, L.; Murray, V. Examining the relationship between infectious diseases and flooding in Europe: A systematic literature review and summary of possible public health interventions. Disaster Health 2013, 1, 117-127. [CrossRef] [PubMed]

87. Sena, A.; Barcellos, C.; Freitas, C.; Corvalan, C. Managing the health impacts of drought in Brazil. Int. J. Environ. Res. Public Health 2014, 11, 10737-10751. [CrossRef] [PubMed]

88. Stanke, C.; Kerac, M.; Prudhomme, C.; Medlock, J.; Murray, V. Health effects of drought: A systematic review of the evidence. PLoS Curr. 2013, 5. [CrossRef] [PubMed]

89. Yusa, A.; Berry, P.; Cheng J, J.; Ogden, N.; Bonsal, B.; Stewart, R.; Waldick, R. Climate Change, Drought and Human Health in Canada. Int. J. Environ. Res. Public Health 2015, 12, 8359-8412. [CrossRef] [PubMed]

90. Phung, D.; Huang, C.; Rutherford, S.; Chu, C.; Wang, X.; Nguyen, M. Climate change, water quality, and water-related diseases in the Mekong Delta Basin: A systematic review. Asia Pac. J. Public Health 2015, 27, 265-276. [CrossRef] [PubMed]

91. De Buck, E.; Borra, V.; De Weerdt, E.; Vande Veegaete, A.; Vandekerckhove, P. A systematic review of the amount of water per person per day needed to prevent morbidity and mortality in (post-)disaster settings. PLoS ONE 2015, 10, e0126395. [CrossRef] [PubMed]

92. Ramesh, A.; Blanchet, K.; Ensink, J.H.; Roberts, B. Evidence on the Effectiveness of Water, Sanitation, and Hygiene (WASH) Interventions on Health Outcomes in Humanitarian Crises: A Systematic Review. PLoS ONE 2015, 10, e0124688. [CrossRef] [PubMed]

93. Yates, T.; Lantagne, D.; Mintz, E.; Quick, R. The impact of water, sanitation, and hygiene interventions on the health and well-being of people living with HIV: A systematic review. J. Acquir. Immune Defic. Syndr. 2015, 68 (Suppl. 3), S318-S330. [CrossRef] [PubMed]

94. Murphy, H.M.; Pintar, K.D.; McBean, E.A.; Thomas, M.K. A systematic review of waterborne disease burden methodologies from developed countries. J. Water Health 2014, 12, 634-655. [CrossRef] [PubMed]

95. Wolf, J.; Pruss-Ustun, A.; Cumming, O.; Bartram, J.; Bonjour, S.; Cairncross, S.; Clasen, T.; Colford, J.M., Jr.; Curtis, V.; De France, J.; et al. Assessing the impact of drinking water and sanitation on diarrhoeal disease in low- and middle-income settings: Systematic review and meta-regression. Trop. Med. Int. Health 2014, 19, 928-942. [CrossRef] [PubMed]

96. Benova, L.; Cumming, O.; Campbell, O.M. Systematic review and meta-analysis: Association between water and sanitation environment and maternal mortality. Trop. Med. Int. Health 2014, 19, 368-387. [CrossRef] [PubMed]

97. Stelmach, R.D.; Clasen, T. Household water quantity and health: A systematic review. Int. J. Environ. Res. Public Health 2015, 12, 5954-5974. [CrossRef] [PubMed]

98. Fewtrell, L.; Kaufmann, R.B.; Kay, D.; Enanoria, W.; Haller, L.; Colford, J.M., Jr. Water, sanitation, and hygiene interventions to reduce diarrhoea in less developed countries: A systematic review and meta-analysis. Lancet Infect. Dis. 2005, 5, 42-52. [CrossRef]

99. Wright, J.; Gundry, S.; Conroy, R. Household drinking water in developing countries: A systematic review of microbiological contamination between source and point-of-use. Trop. Med. Int. Health 2004, 9, 106-117. [CrossRef] [PubMed]

100. Clasen, T.; Schmidt, W.P.; Rabie, T.; Roberts, I.; Cairncross, S. Interventions to improve water quality for preventing diarrhoea: Systematic review and meta-analysis. BMJ 2007, 334, 782. [CrossRef] [PubMed]

101. Peletz, R.; Mahin, T.; Elliott, M.; Harris, M.S.; Chan, K.S.; Cohen, M.S.; Bartram, J.K.; Clasen, T.F. Water, sanitation, and hygiene interventions to improve health among people living with HIV /AIDS: A systematic review. AIDS 2013, 27, 2593-2601. [CrossRef] [PubMed]

102. Dreibelbis, R.; Winch, P.J.; Leontsini, E.; Hulland, K.R.; Ram, P.K.; Unicomb, L.; Luby, S.P. The Integrated Behavioural Model for Water, Sanitation, and Hygiene: A systematic review of behavioural models and a framework for designing and evaluating behaviour change interventions in infrastructure-restricted settings. BMC Public Health 2013, 13, 1015. [CrossRef] [PubMed]

103. Loevinsohn, M.; Mehta, L.; Cuming, K.; Nicol, A.; Cumming, O.; Ensink, J.H. The cost of a knowledge silo: A systematic re-review of water, sanitation and hygiene interventions. Health Policy Plan. 2015, 30, 660-674. [CrossRef] [PubMed] 
104. Ganguly, E.; Sharma, P.K.; Bunker, C.H. Prevalence and risk factors of diarrhea morbidity among under-five children in India: A systematic review and meta-analysis. Indian J. Child Health 2015, 2, 152-160.

105. Arnold, B.F.; Colford, J.M., Jr. Treating water with chlorine at point-of-use to improve water quality and reduce child diarrhea in developing countries: A systematic review and meta-analysis. Am. J. Trop. Med. Hyg. 2007, 76, 354-364. [CrossRef] [PubMed]

106. Ercumen, A.; Gruber, J.S.; Colford, J.M., Jr. Water distribution system deficiencies and gastrointestinal illness: A systematic review and meta-analysis. Environ. Health Perspect. 2014, 122, 651-660. [CrossRef] [PubMed]

107. Pons, W.; Young, I.; Truong, J.; Jones-Bitton, A.; McEwen, S.; Pintar, K.; Papadopoulos, A. A Systematic Review of Waterborne Disease Outbreaks Associated with Small Non-Community Drinking Water Systems in Canada and the United States. PLoS ONE 2015, 10, e0141646. [CrossRef] [PubMed]

108. Waterborne outbreak of gastroenteritis associated with a contaminated municipal water supply, Walkerton, Ontario, May-June 2000. Can. Commun. Dis. Rep. 2000, 26, 170-173.

109. Auld, H.; MacIver, D.; Klaassen, J. Heavy rainfall and waterborne disease outbreaks: The Walkerton example. J. Toxicol. Environ. Health A 2004, 67, 1879-1887. [CrossRef] [PubMed]

110. Guzman Herrador, B.; de Blasio, B.F.; Carlander, A.; Ethelberg, S.; Hygen, H.O.; Kuusi, M.; Lund, V.; Lofdahl, M.; MacDonald, E.; Martinez-Urtaza, J.; et al. Association between heavy precipitation events and waterborne outbreaks in four Nordic countries, 1992-2012. J. Water Health 2016, 14, 1019-1027. [CrossRef] [PubMed]

111. O'Dwyer, J.; Morris Downes, M.; Adley, C.C. The impact of meteorology on the occurrence of waterborne outbreaks of vero cytotoxin-producing Escherichia coli (VTEC): A logistic regression approach. J. Water Health 2016, 14, 39-46. [CrossRef] [PubMed]

112. Drayna, P.; McLellan, S.L.; Simpson, P.; Li, S.H.; Gorelick, M.H. Association between rainfall and pediatric emergency department visits for acute gastrointestinal illness. Environ. Health Perspect. 2010, 118, 1439-1443. [CrossRef] [PubMed]

113. Mosler, H.J. A systematic approach to behavior change interventions for the water and sanitation sector in developing countries: A conceptual model, a review, and a guideline. Int. J. Environ. Health Res. 2012, 22, 431-449. [CrossRef] [PubMed]

114. Evans, W.D.; Pattanayak, S.K.; Young, S.; Buszin, J.; Rai, S.; Bihm, J.W. Social marketing of water and sanitation products: A systematic review of peer-reviewed literature. Soc. Sci. Med. 2014, 110, 18-25. [CrossRef] [PubMed]

115. Jasper, C.; Le, T.T.; Bartram, J. Water and sanitation in schools: A systematic review of the health and educational outcomes. Int. J. Environ. Res. Public Health 2012, 9, 2772-2787. [CrossRef] [PubMed]

116. Bain, R.; Cronk, R.; Hossain, R.; Bonjour, S.; Onda, K.; Wright, J.; Yang, H.; Slaymaker, T.; Hunter, P.; Pruss-Ustun, A.; et al. Global assessment of exposure to faecal contamination through drinking water based on a systematic review. Trop. Med. Int. Health 2014, 19, 917-927. [CrossRef] [PubMed]

117. Guzman Herrador, B.R.; de Blasio, B.F.; MacDonald, E.; Nichols, G.; Sudre, B.; Vold, L.; Semenza, J.C.; Nygard, K. Analytical studies assessing the association between extreme precipitation or temperature and drinking water-related waterborne infections: A review. Environ. Health 2015, 14, 29. [CrossRef] [PubMed]

118. Camargo, E.A.F.; Camargo, J.T.F.; Neves, M.F.; Simoes, L.F.; Bastos, L.A.D.; Magalhaes, L.A.; Zanotti-Magalhaes, E.M. Assessment of the impact of changes in temperature in Biomphalaria glabrata (Say, 1818) melanic and albino variants infected with Schistosoma mansoni (Sambon, 1907). Braz. J. Boil. 2017, 77, 490-494. [CrossRef] [PubMed]

119. McCreesh, N.; Nikulin, G.; Booth, M. Predicting the effects of climate change on Schistosoma mansoni transmission in eastern Africa. Parasites Vectors 2015, 8, 4. [CrossRef] [PubMed]

120. McCreesh, N.; Arinaitwe, M.; Arineitwe, W.; Tukahebwa, E.M.; Booth, M. Effect of water temperature and population density on the population dynamics of Schistosoma mansoni intermediate host snails. Parasites Vectors 2014, 7, 503. [CrossRef] [PubMed]

121. Zhou, X.N.; Yang, G.J.; Yang, K.; Wang, X.H.; Hong, Q.B.; Sun, L.P.; Malone, J.B.; Kristensen, T.K.; Bergquist, N.R.; Utzinger, J. Potential impact of climate change on schistosomiasis transmission in China. Am. J. Trop. Med. Hyg. 2008, 78, 188-194. [CrossRef] [PubMed]

122. Nelson, M.K.; Cruz, B.C.; Buena, K.L.; Nguyen, H.; Sullivan, J.T. Effects of abnormal temperature and starvation on the internal defense system of the schistosome-transmitting snail Biomphalaria glabrata. J. Invertebr. Pathol. 2016, 138, 18-23. [CrossRef] [PubMed] 
123. Pedersen, U.B.; Karagiannis-Voules, D.A.; Midzi, N.; Mduluza, T.; Mukaratirwa, S.; Fensholt, R.; Vennervald, B.J.; Kristensen, T.K.; Vounatsou, P.; Stensgaard, A.S. Comparison of the spatial patterns of schistosomiasis in Zimbabwe at two points in time, spaced twenty-nine years apart: Is climate variability of importance? Geospat. Health 2017, 12, 505. [CrossRef] [PubMed]

124. Stensgaard, A.S.; Booth, M.; Nikulin, G.; McCreesh, N. Combining process-based and correlative models improves predictions of climate change effects on Schistosoma mansoni transmission in eastern Africa. Geospat. Health 2016, 11, 406. [CrossRef] [PubMed]

125. McCreesh, N.; Booth, M. The effect of simulating different intermediate host snail species on the link between water temperature and schistosomiasis risk. PLoS ONE 2014, 9, e87892. [CrossRef] [PubMed]

126. Moore, J.L.; Liang, S.; Akullian, A.; Remais, J.V. Cautioning the use of degree-day models for climate change projections in the presence of parametric uncertainty. Ecol. Appl. 2012, 22, 2237-2247. [CrossRef] [PubMed]

127. Mangal, T.D.; Paterson, S.; Fenton, A. Predicting the impact of long-term temperature changes on the epidemiology and control of schistosomiasis: A mechanistic model. PLoS ONE 2008, 3, e1438. [CrossRef] [PubMed]

128. Abou-El-Naga, I.F. Biomphalaria alexandrina in Egypt: Past, present and future. J. Biosci. 2013, 38, 665-672. [CrossRef] [PubMed]

129. Grimes, J.E.; Croll, D.; Harrison, W.E.; Utzinger, J.; Freeman, M.C.; Templeton, M.R. The relationship between water, sanitation and schistosomiasis: A systematic review and meta-analysis. PLoS Negl. Trop. Dis. 2014, 8, e3296. [CrossRef] [PubMed]

130. Steinmann, P.; Keiser, J.; Bos, R.; Tanner, M.; Utzinger, J. Schistosomiasis and water resources development: Systematic review, meta-analysis, and estimates of people at risk. Lancet Infect. Dis. 2006, 6, 411-425. [CrossRef]

131. Hopkins, D.R.; Ruiz-Tiben, E.; Eberhard, M.L.; Roy, S.L.; Weiss, A.J. Progress Toward Global Eradication of Dracunculiasis-January 2015-June 2016. MMWR Morb. Mortal. Wkly. Rep. 2016, 65, 1112-1116. [CrossRef] [PubMed]

132. Tayeh, A.; Cairncross, S.; Cox, F.E.G. Guinea worm: From Robert Leiper to eradication. Parasitology 2017, 144, 1643-1648. [CrossRef] [PubMed]

133. Enserink, M. Infectious diseases. Guinea worm eradication at risk in South Sudanese war. Science 2014, 343, 236. [CrossRef] [PubMed]

134. Callaway, E. Dogs thwart effort to eradicate Guinea worm. Nature 2016, 529, 10-11. [CrossRef] [PubMed]

135. Wardell, R.; Clements, A.C.A.; Lal, A.; Summers, D.; Llewellyn, S.; Campbell, S.J.; McCarthy, J.; Gray, D.J.; $\mathrm{V}$ Nery, S. An environmental assessment and risk map of Ascaris lumbricoides and Necator americanus distributions in Manufahi District, Timor-Leste. PLoS Negl. Trop. Dis. 2017, 11, e0005565. [CrossRef] [PubMed]

136. Karagiannis-Voules, D.A.; Biedermann, P.; Ekpo, U.F.; Garba, A.; Langer, E.; Mathieu, E.; Midzi, N.; Mwinzi, P.; Polderman, A.M.; Raso, G.; et al. Spatial and temporal distribution of soil-transmitted helminth infection in sub-Saharan Africa: A systematic review and geostatistical meta-analysis. Lancet Infect. Dis. 2015, 15, 74-84. [CrossRef]

137. Strunz, E.C.; Addiss, D.G.; Stocks, M.E.; Ogden, S.; Utzinger, J.; Freeman, M.C. Water, sanitation, hygiene, and soil-transmitted helminth infection: A systematic review and meta-analysis. PLoS Med. 2014, 11, e1001620. [CrossRef] [PubMed]

138. Chalmers, R.M. Waterborne outbreaks of cryptosporidiosis. Ann. Ist. Super. Sanita 2012, 48, 429-446. [CrossRef] [PubMed]

139. Young, I.; Smith, B.A.; Fazil, A. A systematic review and meta-analysis of the effects of extreme weather events and other weather-related variables on Cryptosporidium and Giardia in fresh surface waters. J. Water Health 2015, 13, 1-17. [CrossRef] [PubMed]

140. Gualberto, F.A.; Heller, L. Endemic Cryptosporidium infection and drinking water source: A systematic review and meta-analyses. Water Sci. Technol. 2006, 54, 231-238. [CrossRef] [PubMed]

141. Meireles, L.R.; Ekman, C.C.; de Andrade, H.F., Jr.; Luna, E.J. Human Toxoplasmosis Outbreaks and the Agent Infecting Form. Findings from a Systematic Review. Rev. Inst. Med. Trop. Sao Paulo 2015, 57, 369-376. [CrossRef] [PubMed]

142. Speich, B.; Croll, D.; Furst, T.; Utzinger, J.; Keiser, J. Effect of sanitation and water treatment on intestinal protozoa infection: A systematic review and meta-analysis. Lancet Infect Dis. 2016, 16, 87-99. [CrossRef] 
143. Stuart, J.M.; Orr, H.J.; Warburton, F.G.; Jeyakanth, S.; Pugh, C.; Morris, I.; Sarangi, J.; Nichols, G. Risk factors for sporadic giardiasis: A case-control study in southwestern England. Emerg. Infect. Dis. 2003, 9, 229-233. [CrossRef] [PubMed]

144. Mukherjee, A.K.; Chowdhury, P.; Rajendran, K.; Nozaki, T.; Ganguly, S. Association between Giardia duodenalis and coinfection with other diarrhea-causing pathogens in India. Biomed. Res. Int. 2014, 2014, 786480. [CrossRef] [PubMed]

145. Squire, S.A.; Ryan, U. Cryptosporidium and Giardia in Africa: Current and future challenges. Parasites Vectors 2017, 10, 195. [CrossRef] [PubMed]

146. Moore, S.M.; Azman, A.S.; Zaitchik, B.F.; Mintz, E.D.; Brunkard, J.; Legros, D.; Hill, A.; McKay, H.; Luquero, F.J.; Olson, D.; et al. El Nino and the shifting geography of cholera in Africa. Proc. Natl. Acad. Sci. USA 2017, 114, 4436-4441. [CrossRef] [PubMed]

147. Rebaudet, S.; Sudre, B.; Faucher, B.; Piarroux, R. Environmental determinants of cholera outbreaks in inland Africa: A systematic review of main transmission foci and propagation routes. J. Infect. Dis. 2013, 208 (Suppl. 1), S46-S54. [CrossRef] [PubMed]

148. Rebaudet, S.; Sudre, B.; Faucher, B.; Piarroux, R. Cholera in coastal Africa: A systematic review of its heterogeneous environmental determinants. J. Infect. Dis. 2013, 208 (Suppl. 1), S98-S106. [CrossRef] [PubMed]

149. Martinez, P.P.; Reiner, R.C., Jr.; Cash, B.A.; Rodo, X.; Shahjahan Mondal, M.; Roy, M.; Yunus, M.; Faruque, A.S.; Huq, S.; King, A.A.; et al. Cholera forecast for Dhaka, Bangladesh, with the 2015-2016 El Nino: Lessons learned. PLoS ONE 2017, 12, e0172355. [CrossRef] [PubMed]

150. Semenza, J.C.; Trinanes, J.; Lohr, W.; Sudre, B.; Lofdahl, M.; Martinez-Urtaza, J.; Nichols, G.L.; Rocklov, J. Environmental Suitability of Vibrio Infections in a Warming Climate: An Early Warning System. Environ. Health Perspect. 2017, 125, 107004. [CrossRef] [PubMed]

151. Taylor, D.L.; Kahawita, T.M.; Cairncross, S.; Ensink, J.H. The Impact of Water, Sanitation and Hygiene Interventions to Control Cholera: A Systematic Review. PLoS ONE 2015, 10, e0135676. [CrossRef] [PubMed]

152. Gundry, S.; Wright, J.; Conroy, R. A systematic review of the health outcomes related to household water quality in developing countries. J. Water Health 2004, 2, 1-13. [CrossRef] [PubMed]

153. Boxall, A.B.; Hardy, A.; Beulke, S.; Boucard, T.; Burgin, L.; Falloon, P.D.; Haygarth, P.M.; Hutchinson, T.; Kovats, R.S.; Leonardi, G.; et al. Impacts of climate change on indirect human exposure to pathogens and chemicals from agriculture. Environ. Health Perspect. 2009, 117, 508-514. [CrossRef] [PubMed]

154. Bridge, J.W.; Oliver, D.M.; Chadwick, D.; Godfray, H.C.; Heathwaite, A.L.; Kay, D.; Maheswaran, R.; McGonigle, D.F.; Nichols, G.; Pickup, R.; et al. Engaging with the water sector for public health benefits: Waterborne pathogens and diseases in developed countries. Bull. World Health Organ. 2010, 88, 873-875. [CrossRef] [PubMed]

155. Lee, J.V.N. Legionnaires' disease. In Environmental Medicine; Ayres, J.G.H., Nichols, G.L., Maynard, R.L., Eds.; Hodder Arnold: London, UK, 2010; pp. 224-231.

156. Halsby, K.D.; Joseph, C.A.; Lee, J.V.; Wilkinson, P. The relationship between meteorological variables and sporadic cases of Legionnaires' disease in residents of England and Wales. Epidemiol. Infect. 2014, 142, 2352-2359. [CrossRef] [PubMed]

157. Ricketts, K.D.; Charlett, A.; Gelb, D.; Lane, C.; Lee, J.V.; Joseph, C.A. Weather patterns and Legionnaires' disease: A meteorological study. Epidemiol. Infect. 2009, 137, 1003-1012. [CrossRef] [PubMed]

158. Conza, L.; Casati, S.; Limoni, C.; Gaia, V. Meteorological factors and risk of community-acquired Legionnaires' disease in Switzerland: An epidemiological study. BMJ Open 2013, 3, e002428. [CrossRef] [PubMed]

159. Walser, S.M.; Gerstner, D.G.; Brenner, B.; Holler, C.; Liebl, B.; Herr, C.E. Assessing the environmental health relevance of cooling towers-A systematic review of legionellosis outbreaks. Int. J. Hyg. Environ. Health 2014, 217, 145-154. [CrossRef] [PubMed]

160. Smith, J.K.; Young, M.M.; Wilson, K.L.; Craig, S.B. Leptospirosis following a major flood in Central Queensland, Australia. Epidemiol. Infect. 2012, 141, 585-590. [CrossRef] [PubMed]

161. Dechet, A.M.; Parsons, M.; Rambaran, M.; Mohamed-Rambaran, P.; Florendo-Cumbermack, A.; Persaud, S.; Baboolal, S.; Ari, M.D.; Shadomy, S.V.; Zaki, S.R.; et al. Leptospirosis outbreak following severe flooding: A rapid assessment and mass prophylaxis campaign; Guyana, January-February 2005. PLoS ONE 2012, 7, e39672. [CrossRef] [PubMed] 
162. Naranjo, M.; Suarez, M.; Fernandez, C.; Amador, N.; Gonzalez, M.; Batista, N.; Gonzalez, I.; Valdes, Y.; Infante, J.F.; Sierra, G. Study of a Leptospirosis Outbreak in Honduras Following Hurricane Mitch and Prophylactic Protection of the vax-SPIRAL(R) Vaccine. MEDICC Rev. 2008, 10, 38-42. [PubMed]

163. Mwachui, M.A.; Crump, L.; Hartskeerl, R.; Zinsstag, J.; Hattendorf, J. Environmental and Behavioural Determinants of Leptospirosis Transmission: A Systematic Review. PLoS Negl. Trop. Dis. 2015, 9, e0003843. [CrossRef] [PubMed]

164. Loveday, H.P.; Wilson, J.A.; Kerr, K.; Pitchers, R.; Walker, J.T.; Browne, J. Association between healthcare water systems and Pseudomonas aeruginosa infections: A rapid systematic review. J. Hosp. Infect. 2014, 86, 7-15. [CrossRef] [PubMed]

165. Wisener, L.V.; Sargeant, J.M.; O'Connor, A.M.; Faires, M.C.; Glass-Kaastra, S.K. The use of direct-fed microbials to reduce shedding of Escherichia coli $\mathrm{O} 157$ in beef cattle: A systematic review and meta-analysis. Zoonoses Public Health 2015, 62, 75-89. [CrossRef] [PubMed]

166. Thomas, D.E.; Elliott, E.J. Interventions for preventing diarrhea-associated hemolytic uremic syndrome: Systematic review. BMC Public Health 2013, 13, 799. [CrossRef] [PubMed]

167. Bitler, E.J.; Matthews, J.E.; Dickey, B.W.; Eisenberg, J.N.; Leon, J.S. Norovirus outbreaks: A systematic review of commonly implicated transmission routes and vehicles. Epidemiol. Infect. 2013, 141, 1563-1571. [CrossRef] [PubMed]

168. Stocks, M.E.; Ogden, S.; Haddad, D.; Addiss, D.G.; McGuire, C.; Freeman, M.C. Effect of water, sanitation, and hygiene on the prevention of trachoma: A systematic review and meta-analysis. PLoS Med. 2014, 11, e1001605. [CrossRef] [PubMed]

169. Travers, A.; Strasser, S.; Palmer, S.L.; Stauber, C. The added value of water, sanitation, and hygiene interventions to mass drug administration for reducing the prevalence of trachoma: A systematic review examining. J. Environ. Public Health 2013, 2013, 682093. [CrossRef] [PubMed]

170. Cherrie, M.P.C.; Nichols, G.; LoIacono, G.; Sarran, C.; Hajat, S.; Fleming, L. Pathogen seasonality and links with weather in England and Wales: A big data time series analysis. BMC Public Health 2017, 18, 1067. [CrossRef] [PubMed]

171. Lo Iacono, G.; Armstrong, B.; Fleming, L.E.; Elson, R.; Kovats, S.; Vardoulakis, S.; Nichols, G.L. Challenges in developing methods for quantifying the effects of weather and climate on water-associated diseases: A systematic review. PLoS Negl. Trop. Dis. 2017, 11, e0005659. [CrossRef] [PubMed]

172. Lo Iacono, G.; Nichols, G.L. Modeling the Impact of Environment on Infectious Diseases. In Oxford Research Encyclopedia of Environmental Sciences; Oxford University Press: Oxford, UK, 2017.

173. Hodges, M.; Belle, J.H.; Carlton, E.J.; Liang, S.; Li, H.; Luo, W.; Freeman, M.C.; Liu, Y.; Gao, Y.; Hess, J.J.; et al. Delays reducing waterborne and water-related infectious diseases in China under climate change. Nat. Clim. Chang. 2014, 4, 1109-1115. [CrossRef] [PubMed]

174. Schijven, J.; Bouwknegt, M.; de Roda Husman, A.M.; Rutjes, S.; Sudre, B.; Suk, J.E.; Semenza, J.C. A decision support tool to compare waterborne and foodborne infection and/or illness risks associated with climate change. Risk Anal. 2013, 33, 2154-2167. [CrossRef] [PubMed]

175. Moors, E.; Singh, T.; Siderius, C.; Balakrishnan, S.; Mishra, A. Climate change and waterborne diarrhoea in northern India: Impacts and adaptation strategies. Sci. Total. Environ. 2013, 468-469, S139-S151. [CrossRef] [PubMed]

176. Semenza, J.C.; Houser, C.; Herbst, S.; Rechenburg, A.; Suk, J.E.; Frechen, T.; Kistemann, T. Knowledge Mapping for Climate Change and Food- and Waterborne Diseases. Crit. Rev. Environ. Sci. Technol. 2012, 42, 378-411. [CrossRef] [PubMed]

177. Semenza, J.C.; Herbst, S.; Rechenburg, A.; Suk, J.E.; Hoser, C.; Schreiber, C.; Kistemann, T. Climate Change Impact Assessment of Food- and Waterborne Diseases. Crit. Rev. Environ. Sci. Technol. 2012, 42, 857-890. [CrossRef] [PubMed]

178. Patz, J.A.; Vavrus, S.J.; Uejio, C.K.; McLellan, S.L. Climate change and waterborne disease risk in the Great Lakes region of the U.S. Am. J. Prev. Med. 2008, 35, 451-458. [CrossRef] [PubMed]

179. Schijven, J.F.; de Roda Husman, A.M. Effect of climate changes on waterborne disease in The Netherlands. Water Sci. Technol. 2005, 51, 79-87. [CrossRef] [PubMed]

180. Charron, D.; Thomas, M.; Waltner-Toews, D.; Aramini, J.; Edge, T.; Kent, R.; Maarouf, A.; Wilson, J. Vulnerability of waterborne diseases to climate change in Canada: A review. J. Toxicol. Environ. Health Part A 2004, 67, 1667-1677. [CrossRef] [PubMed] 
181. Hunter, P.R. Climate change and waterborne and vector-borne disease. J. Appl. Microbiol. 2003, 94, 37S-46S. [CrossRef] [PubMed]

182. Lo Iacono, G.; Cunningham, A.A.; Fichet-Calvet, E.; Garry, R.F.; Grant, D.S.; Leach, M.; Moses, L.M.; Nichols, G.; Schieffelin, J.S.; Shaffer, J.G.; et al. A Unified Framework for the Infection Dynamics of Zoonotic Spillover and Spread. PLoS Negl. Trop. Dis. 2016, 10, e0004957. [CrossRef] [PubMed]

183. Rasanen, S.; Lappalainen, S.; Kaikkonen, S.; Hamalainen, M.; Salminen, M.; Vesikari, T. Mixed viral infections causing acute gastroenteritis in children in a waterborne outbreak. Epidemiol. Infect. 2010, 138, 1227-1234. [CrossRef] [PubMed]

184. Mena, K.D.; Gerba, C.P. Waterborne adenovirus. Rev. Environ. Contam. Toxicol. 2009, 198, 133-167. [PubMed]

185. Schuster, F.L.; Visvesvara, G.S. Amebae and ciliated protozoa as causal agents of waterborne zoonotic disease. Vet. Parasitol. 2004, 126, 91-120. [CrossRef] [PubMed]

186. Lamoth, F.; Greub, G. Amoebal pathogens as emerging causal agents of pneumonia. FEMS Microbiol. Rev. 2010, 34, 260-280. [CrossRef] [PubMed]

187. Karanis, P.; Kourenti, C.; Smith, H. Waterborne transmission of protozoan parasites: A worldwide review of outbreaks and lessons learnt. J. Water Health 2007, 5, 1-38. [CrossRef] [PubMed]

188. Nwachuku, N.; Gerba, C.P. Health effects of Acanthamoeba spp. and its potential for waterborne transmission. Rev. Environ. Contam. Toxicol. 2004, 180, 93-131. [PubMed]

189. Marshall, M.M.; Naumovitz, D.; Ortega, Y.; Sterling, C.R. Waterborne protozoan pathogens. Clin. Microbiol. Rev. 1997, 10, 67-85. [PubMed]

190. Baldursson, S.; Karanis, P. Waterborne transmission of protozoan parasites: Review of worldwide outbreaks-An update 2004-2010. Water Res. 2011, 45, 6603-6614. [CrossRef] [PubMed]

191. Anger, C.; Lally, J.M. Acanthamoeba: A review of its potential to cause keratitis, current lens care solution disinfection standards and methodologies, and strategies to reduce patient risk. Eye Contact Lens 2008, 34, 247-253. [CrossRef] [PubMed]

192. Foulks, G.N. Acanthamoeba keratitis and contact lens wear: Static or increasing problem? Eye Contact Lens 2007, 33, 412-414. [CrossRef] [PubMed]

193. Joslin, C.E.; Tu, E.Y.; Shoff, M.E.; Booton, G.C.; Fuerst, P.A.; McMahon, T.T.; Anderson, R.J.; Dworkin, M.S.; Sugar, J.; Davis, F.G.; et al. The association of contact lens solution use and Acanthamoeba keratitis. Am. J. Ophthalmol. 2007, 144, 169-180. [CrossRef] [PubMed]

194. Tanhehco, T.; Colby, K. The clinical experience of Acanthamoeba keratitis at a tertiary care eye hospital. Cornea 2010, 29, 1005-1010. [CrossRef] [PubMed]

195. Meier, P.A.; Mathers, W.D.; Sutphin, J.E.; Folberg, R.; Hwang, T.; Wenzel, R.P. An epidemic of presumed Acanthamoeba keratitis that followed regional flooding. Results of a case-control investigation. Arch. Ophthalmol. 1998, 116, 1090-1094. [CrossRef] [PubMed]

196. Ibrahim, Y.W.; Boase, D.L.; Cree, I.A. Factors affecting the epidemiology of Acanthamoeba keratitis. Ophthalmic Epidemiol. 2007, 14, 53-60. [CrossRef] [PubMed]

197. Chitambar, S.; Gopalkrishna, V.; Chhabra, P.; Patil, P.; Verma, H.; Lahon, A.; Arora, R.; Tatte, V.; Ranshing, S.; Dhale, G.; et al. Diversity in the enteric viruses detected in outbreaks of gastroenteritis from Mumbai, Western India. Int. J. Environ. Res. Public Health 2012, 9, 895-915. [CrossRef] [PubMed]

198. Guerrero-Latorre, L.; Carratala, A.; Rodriguez-Manzano, J.; Calgua, B.; Hundesa, A.; Girones, R. Occurrence of water-borne enteric viruses in two settlements based in Eastern Chad: Analysis of hepatitis E virus, hepatitis A virus and human adenovirus in water sources. J. Water Health 2011, 9, 515-524. [CrossRef] [PubMed]

199. Mellou, K.; Sideroglou, T.; Potamiti-Komi, M.; Kokkinos, P.; Ziros, P.; Georgakopoulou, T.; Vantarakis, A. Epidemiological investigation of two parallel gastroenteritis outbreaks in school settings. BMC Public Health 2013, 13, 241. [CrossRef] [PubMed]

200. Sinclair, R.G.; Jones, E.L.; Gerba, C.P. Viruses in recreational water-borne disease outbreaks: A review. J. Appl. Microbiol. 2009, 107, 1769-1780. [CrossRef] [PubMed]

201. Artieda, J.; Pineiro, L.; Gonzalez, M.; Munoz, M.; Basterrechea, M.; Iturzaeta, A.; Cilla, G. A swimming pool-related outbreak of pharyngoconjunctival fever in children due to adenovirus type 4, Gipuzkoa, Spain, 2008. Euro Surveill. 2009, 14, 19125. [PubMed] 
202. Fong, T.T.; Mansfield, L.S.; Wilson, D.L.; Schwab, D.J.; Molloy, S.L.; Rose, J.B. Massive microbiological groundwater contamination associated with a waterborne outbreak in Lake Erie, South Bass Island, Ohio. Environ. Health Perspect. 2007, 115, 856-864. [CrossRef] [PubMed]

203. Kukkula, M.; Arstila, P.; Klossner, M.L.; Maunula, L.; Bonsdorff, C.H.; Jaatinen, P. Waterborne outbreak of viral gastroenteritis. Scand. J. Infect. Dis. 1997, 29, 415-418. [CrossRef] [PubMed]

204. Wadstrom, T.; Ljungh, A. Aeromonas and Plesiomonas as food- and waterborne pathogens. Int. J. Food Microbiol. 1991, 12, 303-311. [CrossRef]

205. Collado, L.; Figueras, M.J. Taxonomy, epidemiology, and clinical relevance of the genus Arcobacter. Clin. Microbiol. Rev. 2011, 24, 174-192. [CrossRef] [PubMed]

206. Asaolu, S.O.; Ofoezie, I.E.; Odumuyiwa, P.A.; Sowemimo, O.A.; Ogunniyi, T.A. Effect of water supply and sanitation on the prevalence and intensity of Ascaris lumbricoides among pre-school-age children in Ajebandele and Ifewara, Osun State, Nigeria. Trans. R. Soc. Trop. Med. Hyg. 2002, 96, 600-604. [CrossRef]

207. Carneiro, F.F.; Cifuentes, E.; Tellez-Rojo, M.M.; Romieu, I. The risk of Ascaris lumbricoides infection in children as an environmental health indicator to guide preventive activities in Caparao and Alto Caparao, Brazil. Bull. World Health Organ. 2002, 80, 40-46. [PubMed]

208. Pham-Duc, P.; Nguyen-Viet, H.; Hattendorf, J.; Zinsstag, J.; Phung-Dac, C.; Zurbrugg, C.; Odermatt, P. Ascaris lumbricoides and Trichuris trichiura infections associated with wastewater and human excreta use in agriculture in Vietnam. Parasitol. Int. 2013, 62, 172-180. [CrossRef] [PubMed]

209. Divizia, M.; Gabrieli, R.; Donia, D.; Macaluso, A.; Bosch, A.; Guix, S.; Sanchez, G.; Villena, C.; Pinto, R.M.; Palombi, L.; et al. Waterborne gastroenteritis outbreak in Albania. Water Sci. Technol. 2004, 50, 57-61. [CrossRef] [PubMed]

210. Gofti-Laroche, L.; Gratacap-Cavallier, B.; Demanse, D.; Genoulaz, O.; Seigneurin, J.M.; Zmirou, D. Are waterborne astrovirus implicated in acute digestive morbidity (E.MI.R.A. study)? J. Clin. Virol. 2003, 27, 74-82. [CrossRef]

211. Sezen, F.; Aval, E.; Agkurt, T.; Yilmaz, S.; Temel, F.; Gulesen, R.; Korukluoglu, G.; Sucakli, M.B.; Torunoglu, M.A.; Zhu, B.P. A large multi-pathogen gastroenteritis outbreak caused by drinking contaminated water from antique neighbourhood fountains, Erzurum city, Turkey, December 2012. Epidemiol. Infect. 2015, 143, 704-710. [CrossRef] [PubMed]

212. Villena, C.; Gabrieli, R.; Pinto, R.M.; Guix, S.; Donia, D.; Buonomo, E.; Palombi, L.; Cenko, F.; Bino, S.; Bosch, A.; et al. A large infantile gastroenteritis outbreak in Albania caused by multiple emerging rotavirus genotypes. Epidemiol. Infect. 2003, 131, 1105-1110. [CrossRef] [PubMed]

213. Le Guyader, F.S.; Le Saux, J.C.; Ambert-Balay, K.; Krol, J.; Serais, O.; Parnaudeau, S.; Giraudon, H.; Delmas, G.; Pommepuy, M.; Pothier, P.; et al. Aichi virus, norovirus, astrovirus, enterovirus, and rotavirus involved in clinical cases from a French oyster-related gastroenteritis outbreak. J. Clin. Microbiol. 2008, 46, 4011-4017. [CrossRef] [PubMed]

214. Baker, A.; Tahani, D.; Gardiner, C.; Bristow, K.L.; Greenhill, A.R.; Warner, J. Groundwater seeps facilitate exposure to Burkholderia pseudomallei. Appl. Environ. Microbiol. 2011, 77, 7243-7246. [CrossRef] [PubMed]

215. Sapian, M.; Khair, M.T.; How, S.H.; Rajalingam, R.; Sahhir, K.; Norazah, A.; Khebir, V.; Jamalludin, A.R. Outbreak of melioidosis and leptospirosis co-infection following a rescue operation. Med. J. Malays. 2012, 67, 293-297.

216. Inglis, T.J.; O'Reilly, L.; Merritt, A.J.; Levy, A.; Heath, C.H. The aftermath of the Western Australian melioidosis outbreak. Am. J. Trop. Med. Hyg. 2011, 84, 851-857. [CrossRef] [PubMed]

217. Currie, B.J.; Haslem, A.; Pearson, T.; Hornstra, H.; Leadem, B.; Mayo, M.; Gal, D.; Ward, L.; Godoy, D.; Spratt, B.G.; et al. Identification of melioidosis outbreak by multilocus variable number tandem repeat analysis. Emerg. Infect. Dis. 2009, 15, 169-174. [CrossRef] [PubMed]

218. Cheng, A.C.; Jacups, S.P.; Gal, D.; Mayo, M.; Currie, B.J. Extreme weather events and environmental contamination are associated with case-clusters of melioidosis in the Northern Territory of Australia. Int. J. Epidemiol. 2006, 35, 323-329. [CrossRef] [PubMed]

219. Ashbolt, N.J. Microbial contamination of drinking water and disease outcomes in developing regions. Toxicology 2004, 198, 229-238. [CrossRef] [PubMed]

220. Currie, B.J.; Mayo, M.; Anstey, N.M.; Donohoe, P.; Haase, A.; Kemp, D.J. A cluster of melioidosis cases from an endemic region is clonal and is linked to the water supply using molecular typing of Burkholderia pseudomallei isolates. Am. J. Trop. Med. Hyg. 2001, 65, 177-179. [CrossRef] [PubMed] 
221. Inglis, T.J.; Garrow, S.C.; Henderson, M.; Clair, A.; Sampson, J.; O’Reilly, L.; Cameron, B. Burkholderia pseudomallei traced to water treatment plant in Australia. Emerg. Infect. Dis. 2000, 6, 56-59. [PubMed]

222. Inglis, T.J.; Garrow, S.C.; Adams, C.; Henderson, M.; Mayo, M.; Currie, B.J. Acute melioidosis outbreak in Western Australia. Epidemiol. Infect. 1999, 123, 437-443. [CrossRef] [PubMed]

223. Inglis, T.J.; Garrow, S.C.; Adams, C.; Henderson, M.; Mayo, M. Dry-season outbreak of melioidosis in Western Australia. Lancet 1998, 352, 1600. [CrossRef]

224. Merianos, A.; Patel, M.; Lane, J.M.; Noonan, C.N.; Sharrock, D.; Mock, P.A.; Currie, B. The 1990-1991 outbreak of melioidosis in the Northern Territory of Australia: Epidemiology and environmental studies. Southeast Asian J. Trop. Med. Public Health 1993, 24, 425-435. [PubMed]

225. Nasser, R.M.; Rahi, A.C.; Haddad, M.F.; Daoud, Z.; Irani-Hakime, N.; Almawi, W.Y. Outbreak of Burkholderia cepacia bacteremia traced to contaminated hospital water used for dilution of an alcohol skin antiseptic. Infect. Control Hosp. Epidemiol. 2004, 25, 231-239. [CrossRef] [PubMed]

226. Roberts, L.A.; Collignon, P.J.; Cramp, V.B.; Alexander, S.; McFarlane, A.E.; Graham, E.; Fuller, A.; Sinickas, V.; Hellyar, A. An Australia-wide epidemic of Pseudomonas pickettii bacteraemia due to contaminated "sterile" water for injection. Med. J. Aust. 1990, 152, 652-655. [PubMed]

227. Romero-Gomez, M.P.; Quiles-Melero, M.I.; Pena Garcia, P.; Gutierrez Altes, A.; Garcia de Miguel, M.A.; Jimenez, C.; Valdezate, S.; Saez Nieto, J.A. Outbreak of Burkholderia cepacia bacteremia caused by contaminated chlorhexidine in a hemodialysis unit. Infect. Control Hosp. Epidemiol. 2008, 29, 377-378. [CrossRef] [PubMed]

228. Rutala, W.A.; Weber, D.J.; Thomann, C.A.; John, J.F.; Saviteer, S.M.; Sarubbi, F.A. An outbreak of Pseudomonas cepacia bacteremia associated with a contaminated intra-aortic balloon pump. J. Thorac. Cardiovasc. Surg. 1988, 96, 157-161. [PubMed]

229. Schaffner, W.; Reisig, G.; Verrall, R.A. Outbreak of Pseudomonas cepacia infection due to contaminated anaesthetics. Lancet 1973, 1, 1050-1051. [CrossRef]

230. Conly, J.M.; Klass, L.; Larson, L.; Kennedy, J.; Low, D.E.; Harding, G.K. Pseudomonas cepacia colonization and infection in intensive care units. Can. Med. Assoc. J. 1986, 134, 363-366.

231. Kotsanas, D.; Brett, J.; Kidd, T.J.; Stuart, R.L.; Korman, T.M. Disinfection of Burkholderia cepacia complex from non-touch taps in a neonatal nursery. J. Perinat. Med. 2008, 36, 235-239. [CrossRef] [PubMed]

232. Antony, B.; Cherian, E.V.; Boloor, R.; Shenoy, K.V. A sporadic outbreak of Burkholderia cepacia complex bacteremia in pediatric intensive care unit of a tertiary care hospital in coastal Karnataka, South India. Indian J. Pathol. Microbiol. 2016, 59, 197-199. [CrossRef] [PubMed]

233. Douce, R.W.; Zurita, J.; Sanchez, O.; Cardenas Aldaz, P. Investigation of an outbreak of central venous catheter-associated bloodstream infection due to contaminated water. Infect. Control Hosp. Epidemiol. 2008, 29, 364-366. [CrossRef] [PubMed]

234. Kaitwatcharachai, C.; Silpapojakul, K.; Jitsurong, S.; Kalnauwakul, S. An outbreak of Burkholderia cepacia bacteremia in hemodialysis patients: An epidemiologic and molecular study. Am. J. Kidney Dis. 2000, 36, 199-204. [CrossRef] [PubMed]

235. Lee, J.K. Two outbreaks of Burkholderia cepacia nosocomial infection in a neonatal intensive care unit. J. Paediatr. Child Health 2008, 44, 62-66. [CrossRef] [PubMed]

236. Lee, S.; Han, S.W.; Kim, G.; Song, D.Y.; Lee, J.C.; Kwon, K.T. An outbreak of Burkholderia cenocepacia associated with contaminated chlorhexidine solutions prepared in the hospital. Am. J. Infect. Control 2013, 41, e93-e96. [CrossRef] [PubMed]

237. Loukil, C.; Saizou, C.; Doit, C.; Bidet, P.; Mariani-Kurkdjian, P.; Aujard, Y.; Beaufils, F.; Bingen, E. Epidemiologic investigation of Burkholderia cepacia acquisition in two pediatric intensive care units. Infect. Control Hosp. Epidemiol. 2003, 24, 707-710. [CrossRef] [PubMed]

238. Lucero, C.A.; Cohen, A.L.; Trevino, I.; Rupp, A.H.; Harris, M.; Forkan-Kelly, S.; Noble-Wang, J.; Jensen, B.; Shams, A.; Arduino, M.J.; et al. Outbreak of Burkholderia cepacia complex among ventilated pediatric patients linked to hospital sinks. Am. J. Infect. Control 2011, 39, 775-778. [CrossRef] [PubMed]

239. Magalhaes, M.; Doherty, C.; Govan, J.R.; Vandamme, P. Polyclonal outbreak of Burkholderia cepacia complex bacteraemia in haemodialysis patients. J. Hosp. Infect. 2003, 54, 120-123. [CrossRef]

240. Moreira, B.M.; Leobons, M.B.; Pellegrino, F.L.; Santos, M.; Teixeira, L.M.; de Andrade Marques, E.; Sampaio, J.L.; Pessoa-Silva, C.L. Ralstonia pickettii and Burkholderia cepacia complex bloodstream infections related to infusion of contaminated water for injection. J. Hosp. Infect. 2005, 60, 51-55. [CrossRef] [PubMed] 
241. Paul, L.M.; Hegde, A.; Pai, T.; Shetty, S.; Baliga, S.; Shenoy, S. An Outbreak of Burkholderia cepacia Bacteremia in a Neonatal Intensive Care Unit. Indian J. Pediatr. 2016, 83, 285-288. [CrossRef] [PubMed]

242. Peterson, A.E.; Chitnis, A.S.; Xiang, N.; Scaletta, J.M.; Geist, R.; Schwartz, J.; Dement, J.; Lawlor, E.; Lipuma, J.J.; O'Connell, H.; et al. Clonally related Burkholderia contaminans among ventilated patients without cystic fibrosis. Am. J. Infect. Control 2013, 41, 1298-1300. [CrossRef] [PubMed]

243. Rosengarten, D.; Block, C.; Hidalgo-Grass, C.; Temper, V.; Gross, I.; Budin-Mizrahi, A.; Berkman, N.; Benenson, S. Cluster of pseudoinfections with Burkholderia cepacia associated with a contaminated washer-disinfector in a bronchoscopy unit. Infect. Control Hosp. Epidemiol. 2010, 31, 769-771. [CrossRef] [PubMed]

244. Singhal, T.; Shah, S.; Naik, R. Outbreak of Burkholderia cepacia complex bacteremia in a chemotherapy day care unit due to intrinsic contamination of an antiemetic drug. Indian J. Med. Microbiol. 2015, 33, 117-119. [CrossRef] [PubMed]

245. Souza, A.V.; Moreira, C.R.; Pasternak, J.; Hirata Mde, L.; Saltini, D.A.; Caetano, V.C.; Ciosak, S.; Azevedo, F.M.; Severino, P.; Vandamme, P.; et al. Characterizing uncommon Burkholderia cepacia complex isolates from an outbreak in a haemodialysis unit. J. Med. Microbiol. 2004, 53, 999-1005. [CrossRef] [PubMed]

246. Latifi, A.R.; Niyyati, M.; Lorenzo-Morales, J.; Haghighi, A.; Seyyed Tabaei, S.J.; Lasjerdi, Z. Presence of Balamuthia mandrillaris in hot springs from Mazandaran province, northern Iran. Epidemiol. Infect. 2016, 144, 2456-2461. [CrossRef] [PubMed]

247. Retana-Moreira, L.; Abrahams-Sandi, E.; Cabello-Vilchez, A.M.; Reyes-Batlle, M.; Valladares, B.; Martinez-Carretero, E.; Pinero, J.E.; Lorenzo-Morales, J. Isolation and molecular characterization of Acanthamoeba and Balamuthia mandrillaris from combination shower units in Costa Rica. Parasitol. Res. 2014, 113, 4117-4122. [CrossRef] [PubMed]

248. Lares-Jimenez, L.F.; Booton, G.C.; Lares-Villa, F.; Velazquez-Contreras, C.A.; Fuerst, P.A. Genetic analysis among environmental strains of Balamuthia mandrillaris recovered from an artificial lagoon and from soil in Sonora, Mexico. Exp. Parasitol. 2014, 145, S57-S61. [CrossRef] [PubMed]

249. Pindyck, T.N.; Dvorscak, L.E.; Hart, B.L.; Palestine, M.D.; Gallant, J.E.; Allen, S.E.; SantaCruz, K.S. Fatal Granulomatous Amebic Encephalitis Due to Balamuthia mandrillaris in New Mexico: A Case Report. Open Forum Infect. Dis. 2014, 1, ofu062. [CrossRef] [PubMed]

250. Walzer, P.D.; Judson, F.N.; Murphy, K.B.; Healy, G.R.; English, D.K.; Schultz, M.G. Balantidiasis outbreak in Truk. Am. J. Trop. Med. Hyg. 1973, 22, 33-41. [CrossRef] [PubMed]

251. Schuster, F.L.; Ramirez-Avila, L. Current world status of Balantidium coli. Clin. Microbiol. Rev. 2008, 21, 626-638. [CrossRef] [PubMed]

252. Bellanger, A.P.; Scherer, E.; Cazorla, A.; Grenouillet, F. Dysenteric syndrome due to Balantidium coli: A case report. New Microbiol. 2013, 36, 203-205. [PubMed]

253. Guglielmetti, P.; Cellesi, C.; Figura, N.; Rossolini, A. Family outbreak of Blastocystis hominis associated gastroenteritis. Lancet 1989, 2, 1394. [CrossRef]

254. Kurt, O.; Dogruman Al, F.; Tanyuksel, M. Eradication of Blastocystis in humans: Really necessary for all? Parasitol. Int. 2016, 65, 797-801. [CrossRef] [PubMed]

255. Dagci, H.; Kurt, O.; Demirel, M.; Mandiracioglu, A.; Aydemir, S.; Saz, U.; Bart, A.; VAN Gool, T. Epidemiological and diagnostic features of blastocystis infection in symptomatic patients in izmir province, Turkey. Iran. J. Parasitol. 2014, 9, 519-529. [PubMed]

256. Chandramathi, S.; Suresh, K.; Anita, Z.B.; Kuppusamy, U.R. Infections of Blastocystis hominis and microsporidia in cancer patients: Are they opportunistic? Trans. R. Soc. Trop. Med. Hyg. 2012, 106, 267-269. [CrossRef] [PubMed]

257. Smith, H.; Nichols, R.A. Zoonotic protozoa-Food for thought. Parassitologia 2006, 48, 101-104. [PubMed]

258. Tuncay, S.; Delibas, S.; Inceboz, T.; Over, L.; Oral, A.M.; Akisu, C.; Aksoy, U. An outbreak of gastroenteritis associated with intestinal parasites. Turk. Parazitol. Derg. 2008, 32, 249-252.

259. Jimenez-Gonzalez, D.E.; Martinez-Flores, W.A.; Reyes-Gordillo, J.; Ramirez-Miranda, M.E.; Arroyo-Escalante, S.; Romero-Valdovinos, M.; Stark, D.; Souza-Saldivar, V.; Martinez-Hernandez, F.; Flisser, A.; et al. Blastocystis infection is associated with irritable bowel syndrome in a Mexican patient population. Parasitol. Res. 2012, 110, 1269-1275. [CrossRef] [PubMed]

260. Iaconelli, M.; Divizia, M.; Della Libera, S.; Di Bonito, P.; La Rosa, G. Frequent Detection and Genetic Diversity of Human Bocavirus in Urban Sewage Samples. Food Environ. Virol. 2016, 8, 289-295. [CrossRef] [PubMed] 
261. Gubbels, S.M.; Kuhn, K.G.; Larsson, J.T.; Adelhardt, M.; Engberg, J.; Ingildsen, P.; Hollesen, L.W.; Muchitsch, S.; Molbak, K.; Ethelberg, S. A waterborne outbreak with a single clone of Campylobacter jejuni in the Danish town of Koge in May 2010. Scand. J. Infect. Dis. 2012, 44, 586-594. [CrossRef] [PubMed]

262. Karagiannis, I.; Sideroglou, T.; Gkolfinopoulou, K.; Tsouri, A.; Lampousaki, D.; Velonakis, E.N.; Scoulica, E.V.; Mellou, K.; Panagiotopoulos, T.; Bonovas, S. A waterborne Campylobacter jejuni outbreak on a Greek island. Epidemiol. Infect. 2010, 138, 1726-1734. [CrossRef] [PubMed]

263. Jakopanec, I.; Borgen, K.; Vold, L.; Lund, H.; Forseth, T.; Hannula, R.; Nygard, K. A large waterborne outbreak of campylobacteriosis in Norway: The need to focus on distribution system safety. BMC Infect. Dis. 2008, 8, 128. [CrossRef] [PubMed]

264. Richardson, G.; Thomas, D.R.; Smith, R.M.; Nehaul, L.; Ribeiro, C.D.; Brown, A.G.; Salmon, R.L. A community outbreak of Campylobacter jejuni infection from a chlorinated public water supply. Epidemiol. Infect. 2007, 135, 1151-1158. [CrossRef] [PubMed]

265. Martin, S.; Penttinen, P.; Hedin, G.; Ljungstrom, M.; Allestam, G.; Andersson, Y.; Giesecke, J. A case-cohort study to investigate concomitant waterborne outbreaks of Campylobacter and gastroenteritis in Soderhamn, Sweden, 2002-3. J. Water Health 2006, 4, 417-424. [CrossRef] [PubMed]

266. Kuusi, M.; Nuorti, J.P.; Hanninen, M.L.; Koskela, M.; Jussila, V.; Kela, E.; Miettinen, I.; Ruutu, P. A large outbreak of campylobacteriosis associated with a municipal water supply in Finland. Epidemiol. Infect. 2005, 133, 593-601. [CrossRef] [PubMed]

267. Merritt, A.; Miles, R.; Bates, J. An outbreak of Campylobacter enteritis on an island resort, north Queensland. Commun. Dis. Intell. 1999, 23, 215-219, discussion 220. [PubMed]

268. Engberg, J.; Gerner-Smidt, P.; Scheutz, F.; Moller Nielsen, E.; On, S.L.; Molbak, K. Water-borne Campylobacter jejuni infection in a Danish town-A 6-week continuous source outbreak. Clin. Microbiol. Infect. 1998, 4, 648-656. [CrossRef] [PubMed]

269. Thomas, K.M.; Charron, D.F.; Waltner-Toews, D.; Schuster, C.; Maarouf, A.R.; Holt, J.D. A role of high impact weather events in waterborne disease outbreaks in Canada, 1975-2001. Int. J. Environ. Health Res. 2006, 16, 167-180. [CrossRef] [PubMed]

270. Nichols, G.L. Fly transmission of Campylobacter. Emerg. Infect. Dis. 2005, 11, 361-364. [CrossRef] [PubMed]

271. Karaman, U.; Koloren, Z.; Seferoglu, O.; Ayaz, E.; Demirel, E. Presence of Parasites in Environmental Waters in Samsun and Its Districts. Turk. Parazitol. Derg. 2017, 41, 19-21. [CrossRef] [PubMed]

272. Hatam-Nahavandi, K.; Mahvi, A.H.; Mohebali, M.; Keshavarz, H.; Mobedi, I.; Rezaeian, M. Detection of parasitic particles in domestic and urban wastewaters and assessment of removal efficiency of treatment plants in Tehran, Iran. J. Environ. Health Sci. Eng. 2015, 13, 4. [CrossRef] [PubMed]

273. Mora, L.; Martinez, I.; Figuera, L.; Segura, M.; Del Valle, G. Protozoans in superficial waters and faecal samples of individuals of rural populations of the Montes municipality, Sucre state, Venezuela. Investig. Clin. 2010, 51, 457-466.

274. Elshazly, A.M.; Elsheikha, H.M.; Soltan, D.M.; Mohammad, K.A.; Morsy, T.A. Protozoal pollution of surface water sources in Dakahlia Governorate, Egypt. J. Egypt. Soc. Parasitol. 2007, 37, 51-64. [PubMed]

275. Squier, C.; Yu, V.L.; Stout, J.E. Waterborne Nosocomial Infections. Curr. Infect. Dis. Rep. 2000, 2, 490-496. [CrossRef] [PubMed]

276. Wang, J.L.; Chen, M.L.; Lin, Y.E.; Chang, S.C.; Chen, Y.C. Association between contaminated faucets and colonization or infection by nonfermenting gram-negative bacteria in intensive care units in Taiwan. J. Clin. Microbiol. 2009, 47, 3226-3230. [CrossRef] [PubMed]

277. Moore, L.S.; Owens, D.S.; Jepson, A.; Turton, J.F.; Ashworth, S.; Donaldson, H.; Holmes, A.H. Waterborne Elizabethkingia meningoseptica in Adult Critical Care. Emerg. Infect. Dis. 2016, 22, 9-17. [CrossRef] [PubMed]

278. Wang, X.W.; Li, J.; Guo, T.; Zhen, B.; Kong, Q.; Yi, B.; Li, Z.; Song, N.; Jin, M.; Xiao, W.; et al. Concentration and detection of SARS coronavirus in sewage from Xiao Tang Shan Hospital and the 309th Hospital of the Chinese People's Liberation Army. Water Sci. Technol. 2005, 52, 213-221. [CrossRef] [PubMed]

279. Nichols, G.L.C.; Hadfield, S.J. Molecular epidemiology of human cryptosporidiosis. In Cryptosporidium: Parasite and Disease; Cacciò, S.M., Widmer, G., SpringerLink (Online Service), Eds.; Springer: London, UK, 2014; pp. 81-133. 
280. Polgreen, P.M.; Sparks, J.D.; Polgreen, L.A.; Yang, M.; Harris, M.L.; Pentella, M.A.; Cavanaugh, J.E. A statewide outbreak of Cryptosporidium and its association with the distribution of public swimming pools. Epidemiol. Infect. 2012, 140, 1439-1445. [CrossRef] [PubMed]

281. Moreira, N.A.; Bondelind, M. Safe drinking water and waterborne outbreaks. J. Water Health 2017, 15, 83-96. [CrossRef] [PubMed]

282. Mahon, M.; Doyle, S. Waterborne outbreak of cryptosporidiosis in the South East of Ireland: Weighing up the evidence. Ir. J. Med. Sci. 2017, 186, 989-994. [CrossRef] [PubMed]

283. Efstratiou, A.; Ongerth, J.E.; Karanis, P. Waterborne transmission of protozoan parasites: Review of worldwide outbreaks-An update 2011-2016. Water Res. 2017, 114, 14-22. [CrossRef] [PubMed]

284. Serdarevic, F.; Jones, R.C.; Weaver, K.N.; Black, S.R.; Ritger, K.A.; Guichard, F.; Dombroski, P.; Emanuel, B.P.; Miller, L.; Gerber, S.I. Multi-pathogen waterborne disease outbreak associated with a dinner cruise on Lake Michigan. Epidemiol. Infect. 2012, 140, 621-625. [CrossRef] [PubMed]

285. Neira-Munoz, E.; Okoro, C.; McCarthy, N.D. Outbreak of waterborne cryptosporidiosis associated with low oocyst concentrations. Epidemiol. Infect. 2007, 135, 1159-1164. [CrossRef] [PubMed]

286. Samadder, S.R.; Ziegler, P.; Murphy, T.M.; Holden, N.M. Spatial distribution of risk factors for Cryptosporidium spp. transport in an Irish catchment. Water Environ. Res. 2010, 82, 750-758. [CrossRef] [PubMed]

287. Jagai, J.S.; Castronovo, D.A.; Monchak, J.; Naumova, E.N. Seasonality of cryptosporidiosis: A meta-analysis approach. Environ. Res. 2009, 109, 465-478. [CrossRef] [PubMed]

288. Atherton, F.; Newman, C.P.; Casemore, D.P. An outbreak of waterborne cryptosporidiosis associated with a public water supply in the UK. Epidemiol. Infect. 1995, 115, 123-131. [CrossRef] [PubMed]

289. Bridgman, S.A.; Robertson, R.M.; Syed, Q.; Speed, N.; Andrews, N.; Hunter, P.R. Outbreak of cryptosporidiosis associated with a disinfected groundwater supply. Epidemiol. Infect. 1995, 115, 555-566. [CrossRef] [PubMed]

290. Harrison, S.L.; Nelder, R.; Hayek, L.; Mackenzie, I.F.; Casemore, D.P.; Dance, D. Managing a large outbreak of cryptosporidiosis: How to investigate and when to decide to lift a 'boil water' notice. Commun. Dis. Public Health PHLS 2002, 5, 230-239.

291. Patel, S.; Pedraza-Diaz, S.; McLauchlin, J.; Casemore, D.P. Molecular characterisation of Cryptosporidium parvum from two large suspected waterborne outbreaks. Outbreak Control Team South and West Devon 1995, Incident Management Team and Further Epidemiological and Microbiological Studies Subgroup North Thames 1997. Commun. Dis. Public Health PHLS 1998, 1, 231-233.

292. Smith, H.V.; Patterson, W.J.; Hardie, R.; Greene, L.A.; Benton, C.; Tulloch, W.; Gilmour, R.A.; Girdwood, R.W.; Sharp, J.C.; Forbes, G.I. An outbreak of waterborne cryptosporidiosis caused by post-treatment contamination. Epidemiol. Infect. 1989, 103, 703-715. [CrossRef] [PubMed]

293. Risebro, H.L.; Doria, M.F.; Andersson, Y.; Medema, G.; Osborn, K.; Schlosser, O.; Hunter, P.R. Fault tree analysis of the causes of waterborne outbreaks. J. Water Health 2007, 5 (Suppl. 1), 1-18. [CrossRef] [PubMed]

294. Wuhib, T.; Silva, T.M.; Newman, R.D.; Garcia, L.S.; Pereira, M.L.; Chaves, C.S.; Wahlquist, S.P.; Bryan, R.T.; Guerrant, R.L.; Sousa Ade, Q.; et al. Cryptosporidial and microsporidial infections in human immunodeficiency virus-infected patients in northeastern Brazil. J. Infect. Dis. 1994, 170, 494-497. [CrossRef] [PubMed]

295. Scheepstra, D.R.; Lipman, L.J. Swimming in summer. Tijdschr. Diergeneeskd. 2006, 131, 742-744. [PubMed]

296. Herwaldt, B.L.; Craun, G.F.; Stokes, S.L.; Juranek, D.D. Waterborne-disease outbreaks, 1989-1990. MMWR CDC Surveill. Summ. 1991, 40,1-21. [PubMed]

297. Griffiths, D.J.; Saker, M.L. The Palm Island mystery disease 20 years on: A review of research on the cyanotoxin cylindrospermopsin. Environ. Toxicol. 2003, 18, 78-93. [CrossRef] [PubMed]

298. Hawkins, P.R.; Runnegar, M.T.; Jackson, A.R.; Falconer, I.R. Severe hepatotoxicity caused by the tropical cyanobacterium (blue-green alga) Cylindrospermopsis raciborskii (Woloszynska) Seenaya and Subba Raju isolated from a domestic water supply reservoir. Appl. Environ. Microbiol. 1985, 50, 1292-1295. [PubMed]

299. Osborne, N.J.; Shaw, G.R.; Webb, P.M. Health effects of recreational exposure to Moreton Bay, Australia waters during a Lyngbya majuscula bloom. Environ. Int. 2007, 33, 309-314. [CrossRef] [PubMed]

300. Soares, R.M.; Yuan, M.; Servaites, J.C.; Delgado, A.; Magalhaes, V.F.; Hilborn, E.D.; Carmichael, W.W.; Azevedo, S.M. Sublethal exposure from microcystins to renal insufficiency patients in Rio de Janeiro, Brazil. Environ. Toxicol. 2006, 21, 95-103. [CrossRef] [PubMed] 
301. Azevedo, S.M.; Carmichael, W.W.; Jochimsen, E.M.; Rinehart, K.L.; Lau, S.; Shaw, G.R.; Eaglesham, G.K. Human intoxication by microcystins during renal dialysis treatment in Caruaru-Brazil. Toxicology 2002, 181-182, 441-446. [CrossRef]

302. Jochimsen, E.M.; Carmichael, W.W.; An, J.S.; Cardo, D.M.; Cookson, S.T.; Holmes, C.E.; Antunes, M.B.; de Melo Filho, D.A.; Lyra, T.M.; Barreto, V.S.; et al. Liver failure and death after exposure to microcystins at a hemodialysis center in Brazil. N. Engl. J. Med. 1998, 338, 873-878. [CrossRef] [PubMed]

303. El Saadi, O.E.; Esterman, A.J.; Cameron, S.; Roder, D.M. Murray River water, raised cyanobacterial cell counts, and gastrointestinal and dermatological symptoms. Med. J. Aust. 1995, 162, 122-125. [PubMed]

304. Ortega, Y.R.; Sanchez, R. Update on Cyclospora cayetanensis, a food-borne and waterborne parasite. Clin. Microbiol. Rev. 2010, 23, 218-234. [CrossRef] [PubMed]

305. Wurtz, R. Cyclospora: A newly identified intestinal pathogen of humans. Clin. Infect. Dis. 1994, 18, 620-623. [CrossRef] [PubMed]

306. Tichadou, L.; Glaizal, M.; Armengaud, A.; Grossel, H.; Lemee, R.; Kantin, R.; Lasalle, J.L.; Drouet, G.; Rambaud, L.; Malfait, P.; et al. Health impact of unicellular algae of the Ostreopsis genus blooms in the Mediterranean Sea: Experience of the French Mediterranean coast surveillance network from 2006 to 2009. Clin. Toxicol. 2010, 48, 839-844. [CrossRef] [PubMed]

307. Hossen, V.; Jourdan-da Silva, N.; Guillois-Becel, Y.; Marchal, J.; Krys, S. Food poisoning outbreaks linked to mussels contaminated with okadaic acid and ester dinophysistoxin-3 in France, June 2009. Euro Surveill. 2011, 16. [CrossRef]

308. Barroso Garcia, P.; Rueda de la Puerta, P.; Parron Carreno, T.; Marin Martinez, P.; Guillen Enriquez, J. An epidemic outbreak with respiratory symptoms in the province of Almeria [Spain] due to toxic microalgae exposure. Gac. Sanit. 2008, 22, 578-584. [PubMed]

309. Watkins, S.M.; Reich, A.; Fleming, L.E.; Hammond, R. Neurotoxic shellfish poisoning. Mar. Drugs 2008, 6, 431-455. [CrossRef] [PubMed]

310. La Barbera-Sanchez, A.; Franco Soler, J.; Rojas de Astudillo, L.; Chang-Yen, I. Paralytic shellfish poisoning (PSP) in Margarita Island, Venezuela. Rev. Biol. Trop. 2004, 52 (Suppl. 1), 89-98. [PubMed]

311. Anderson, D.M.; Sullivan, J.J.; Reguera, B. Paralytic shellfish poisoning in northwest Spain: The toxicity of the dinoflagellate Gymnodinium catenatum. Toxicon 1989, 27, 665-674. [CrossRef]

312. Tan, C.T.; Lee, E.J. Paralytic shellfish poisoning in Singapore. Ann. Acad. Med. Singap. 1986, 15, 77-79. [PubMed]

313. Kat, M. Diarrhetic mussel poisoning in the Netherlands related to the dinoflagellate Dinophysis acuminata. Antonie Van Leeuwenhoek 1983, 49, 417-427. [PubMed]

314. Popkiss, M.E.; Horstman, D.A.; Harpur, D. Paralytic shellfish poisoning. A report of 17 cases in Cape Town. S. Afr. Med. J. 1979, 55, 1017-1023. [PubMed]

315. Morse, E.V. Paralytic shellfish poisoning: A review. J. Am. Vet. Med. Assoc. 1977, 171, 1178-1180. [PubMed]

316. Pottier, I.; Vernoux, J.P.; Lewis, R.J. Ciguatera fish poisoning in the Caribbean islands and Western Atlantic. Rev. Environ. Contam. Toxicol. 2001, 168, 99-141. [PubMed]

317. Juranovic, L.R.; Park, D.L. Foodborne toxins of marine origin: Ciguatera. Rev. Environ. Contam. Toxicol. 1991, 117, 51-94. [PubMed]

318. Taylor, M.; McIntyre, L.; Ritson, M.; Stone, J.; Bronson, R.; Bitzikos, O.; Rourke, W.; Galanis, E.; Team, O.I. Outbreak of diarrhetic shellfish poisoning associated with mussels, British Columbia, Canada. Mar. Drugs 2013, 11, 1669-1676. [CrossRef] [PubMed]

319. Chen, T.; Xu, X.; Wei, J.; Chen, J.; Miu, R.; Huang, L.; Zhou, X.; Fu, Y.; Yan, R.; Wang, Z.; et al. Food-borne disease outbreak of diarrhetic shellfish poisoning due to toxic mussel consumption: The first recorded outbreak in China. PLoS ONE 2013, 8, e65049. [CrossRef] [PubMed]

320. Economou, V.; Papadopoulou, C.; Brett, M.; Kansouzidou, A.; Charalabopoulos, K.; Filioussis, G.; Seferiadis, K. Diarrheic shellfish poisoning due to toxic mussel consumption: The first recorded outbreak in Greece. Food Addit. Contam. 2007, 24, 297-305. [CrossRef] [PubMed]

321. Chung, P.H.; Chuang, S.K.; Tsang, T. Consumption of viscera as the most important risk factor in the largest outbreak of shellfish poisoning in Hong Kong, 2005. Southeast Asian J. Trop. Med. Public Health 2006, 37, 120-125. [PubMed]

322. De Schrijver, K.; Maes, I.; De Man, L.; Michelet, J. An outbreak of diarrhoeic shellfish poisoning in Antwerp, Belgium. Euro Surveill. 2002, 7, 138-141. [CrossRef] [PubMed] 
323. James, K.J.; Gillman, M.; Amandi, M.F.; Lopez-Rivera, A.; Puente, P.F.; Lehane, M.; Mitrovic, S.; Furey, A. Amnesic shellfish poisoning toxins in bivalve molluscs in Ireland. Toxicon 2005, 46, 852-858. [CrossRef] [PubMed]

324. James, K.J.; Furey, A.; Lehane, M.; Ramstad, H.; Aune, T.; Hovgaard, P.; Morris, S.; Higman, W.; Satake, M.; Yasumoto, T. First evidence of an extensive northern European distribution of azaspiracid poisoning (AZP) toxins in shellfish. Toxicon 2002, 40,909-915. [CrossRef]

325. Pfannkuchen, M.; Godrijan, J.; Pfannkuchen, D.M.; Ivesa, L.; Kruzic, P.; Ciminiello, P.; Dell'Aversano, C.; Dello Iacovo, E.; Fattorusso, E.; Forino, M.; et al. Toxin-producing Ostreopsis cf. ovata are likely to bloom undetected along coastal areas. Environ. Sci. Technol. 2012, 46, 5574-5582. [CrossRef] [PubMed]

326. Jeffery, B.; Barlow, T.; Moizer, K.; Paul, S.; Boyle, C. Amnesic shellfish poison. Food Chem. Toxicol. 2004, 42, 545-557. [CrossRef] [PubMed]

327. Perl, T.M.; Bedard, L.; Kosatsky, T.; Hockin, J.C.; Todd, E.C.; McNutt, L.A.; Remis, R.S. Amnesic shellfish poisoning: A new clinical syndrome due to domoic acid. Can. Dis. Wkly. Rep. 1990, 16 (Suppl. 1E), 7-8. [PubMed]

328. Pulido, O.M. Domoic acid toxicologic pathology: A review. Mar. Drugs 2008, 6, 180-219. [CrossRef] [PubMed]

329. Vale, P.; de M Sampayo, M.A. First confirmation of human diarrhoeic poisonings by okadaic acid esters after ingestion of razor clams (Solen marginatus) and green crabs (Carcinus maenas) in Aveiro lagoon, Portugal and detection of okadaic acid esters in phytoplankton. Toxicon 2002, 40, 989-996. [CrossRef]

330. Garcia, C.; Schonstedt, V.; Santelices, J.P.; Lagos, N. High amount of dinophysistoxin-3 in Mytilus chilensis collected in Seno de Reloncavi, chile, during massive human intoxication associated with outbreak of Vibrio parahaemolyticus. J. Toxicol. Sci. 2006, 31, 305-314. [CrossRef] [PubMed]

331. McIntyre, L.; Cassis, D.; Haigh, N. Formation of a volunteer harmful algal bloom network in British Columbia, Canada, following an outbreak of diarrhetic shellfish poisoning. Mar. Drugs 2013, 11, 4144-4157. [CrossRef] [PubMed]

332. Chevallier, O.P.; Graham, S.F.; Alonso, E.; Duffy, C.; Silke, J.; Campbell, K.; Botana, L.M.; Elliott, C.T. New insights into the causes of human illness due to consumption of azaspiracid contaminated shellfish. Sci. Rep. 2015, 5, 9818. [CrossRef] [PubMed]

333. Farrell, H.; Zammit, A.; Manning, J.; Shadbolt, C.; Szabo, L.; Harwood, D.T.; McNabb, P.; Turahui, J.A.; van den Berg, D.J. Clinical diagnosis and chemical confirmation of ciguatera fish poisoning in New South Wales, Australia. Commun. Dis. Intell. Q. Rep. 2016, 40, E1-E6. [PubMed]

334. Schlaich, C.; Hagelstein, J.G.; Burchard, G.D.; Schmiedel, S. Outbreak of ciguatera fish poisoning on a cargo ship in the port of hamburg. J. Travel Med. 2012, 19, 238-242. [CrossRef] [PubMed]

335. Nunez, D.; Matute, P.; Garcia, A.; Garcia, P.; Abadia, N. Outbreak of ciguatera food poisoning by consumption of amberjack (Seriola spp.) in the Canary Islands, May 2012. Euro Surveill. 2012, 17, 20188. [PubMed]

336. Yoshikawa Ebesu, J.S.; Hokama, Y. Study of an outbreak of ciguatera fish poisoning in Hong Kong. Toxicon 2006, 48, 467-469. [CrossRef] [PubMed]

337. Wong, C.K.; Hung, P.; Lee, K.L.; Kam, K.M. Study of an outbreak of ciguatera fish poisoning in Hong Kong. Toxicon 2005, 46, 563-571. [CrossRef] [PubMed]

338. Ng, S.; Gregory, J. An outbreak of ciguatera fish poisoning in Victoria. Commun. Dis. Intell. 2000, $24,344-346$. [PubMed]

339. Poli, M.A.; Lewis, R.J.; Dickey, R.W.; Musser, S.M.; Buckner, C.A.; Carpenter, L.G. Identification of Caribbean ciguatoxins as the cause of an outbreak of fish poisoning among U.S. soldiers in Haiti. Toxicon 1997, 35, 733-741. [CrossRef]

340. Lucas, R.E.; Lewis, R.J.; Taylor, J.M. Pacific ciguatoxin-1 associated with a large common-source outbreak of ciguatera in east Arnhem Land, Australia. Nat. Toxins 1997, 5, 136-140. [CrossRef] [PubMed]

341. Morris, P.D.; Campbell, D.S.; Freeman, J.I. Ciguatera fish poisoning: An outbreak associated with fish caught from North Carolina coastal waters. South. Med. J. 1990, 83, 379-382. [CrossRef] [PubMed]

342. Frenette, C.; MacLean, J.D.; Gyorkos, T.W. A large common-source outbreak of ciguatera fish poisoning. J. Infect. Dis. 1988, 158, 1128-1131. [CrossRef] [PubMed]

343. Engleberg, N.C.; Morris, J.G., Jr.; Lewis, J.; McMillan, J.P.; Pollard, R.A.; Blake, P.A. Ciguatera fish poisoning: A major common-source outbreak in the U.S. Virgin Islands. Ann. Intern. Med. 1983, 98, 336-337. [CrossRef] [PubMed] 
344. Tonge, J.I.; Battey, Y.; Forbes, J.J.; Grant, E.M. Ciguatera poisoning: A report of two outbreaks and a probable fatal case in Queensland. Med. J. Aust. 1967, 2, 1088-1090. [PubMed]

345. Durando, P.; Ansaldi, F.; Oreste, P.; Moscatelli, P.; Marensi, L.; Grillo, C.; Gasparini, R.; Icardi, G. The Collaborative Group for the Ligurian Syndromic Algal Surveillance. Ostreopsis ovata and human health: Epidemiological and clinical features of respiratory syndrome outbreaks from a two-year syndromic surveillance, 2005-2006, in north-west Italy. Euro Surveill. 2007, 12, 3212. [PubMed]

346. Centers for Disease Control and Prevention. Renewed transmission of dracunculiasis—Chad, 2010. MMWR Morb. Mortal. Wkly. Rep. 2011, 60, 744-748.

347. Centers for Disease Control and Prevention. Progress toward global eradication of dracunculiasis, January 2010-June 2011. MMWR Morb. Mortal. Wkly. Rep. 2011, 60, 1450-1453.

348. Miri, E.S.; Hopkins, D.R.; Ruiz-Tiben, E.; Keana, A.S.; Withers, P.C., Jr.; Anagbogu, I.N.; Sadiq, L.K.; Kale, O.O.; Edungbola, L.D.; Braide, E.I.; et al. Nigeria's triumph: Dracunculiasis eradicated. Am. J. Trop. Med. Hyg. 2010, 83, 215-225. [CrossRef] [PubMed]

349. Hunter, J.M. Bore holes and the vanishing of guinea worm disease in Ghana's upper region. Soc. Sci. Med. 1997, 45, 71-89. [CrossRef]

350. Hopkins, D.R.; Azam, M.; Ruiz-Tiben, E.; Kappus, K.D. Eradication of dracunculiasis from Pakistan. Lancet 1995, 346, 621-624. [CrossRef]

351. Edungbola, L.D.; Watts, S. An outbreak of dracunculiasis in a peri-urban community of Ilorin, Kwara State, Nigeria. Acta Trop. 1984, 41, 155-163. [PubMed]

352. Steib, K.; Mayer, P. Epidemiology and vectors of Dracunculus medinensis in northwest Burkina Faso, West Africa. Ann. Trop. Med. Parasitol. 1988, 82, 189-199. [CrossRef] [PubMed]

353. Ilegbodu, V.A.; Christensen, B.L.; Wise, R.A.; Ilegbodu, A.E.; Kale, O.O. Source of drinking water supply and transmission of guinea worm disease in Nigeria. Ann. Trop. Med. Parasitol. 1987, 81, 713-718. [CrossRef] [PubMed]

354. Barwick, R.S.; Uzicanin, A.; Lareau, S.; Malakmadze, N.; Imnadze, P.; Iosava, M.; Ninashvili, N.; Wilson, M.; Hightower, A.W.; Johnston, S.; et al. Outbreak of amebiasis in Tbilisi, Republic of Georgia, 1998. Am. J. Trop. Med. Hyg. 2002, 67, 623-631. [CrossRef] [PubMed]

355. Chen, K.T.; Chen, C.J.; Chiu, J.P. A school waterborne outbreak involving both Shigella sonnei and Entamoeba histolytica. J. Environ. Health 2001, 64, 9-13. [PubMed]

356. Carmona, C.; Perdomo, R.; Carbo, A.; Alvarez, C.; Monti, J.; Grauert, R.; Stern, D.; Perera, G.; Lloyd, S.; Bazini, R.; et al. Risk factors associated with human cystic echinococcosis in Florida, Uruguay: Results of a mass screening study using ultrasound and serology. Am. J. Trop. Med. Hyg. 1998, 58, 599-605. [CrossRef] [PubMed]

357. Kramer, M.H. Association between asymptomatic cystic echinococcosis and some types of rural water supplies. Am. J. Trop. Med. Hyg. 1999, 60, 520. [CrossRef] [PubMed]

358. Hernandez, A.; Cardozo, G.; Dematteis, S.; Baz, A.; Trias, N.; Nunez, H.; Barrague, A.; Lopez, L.; Fuentes, J.; Lopez, O.; et al. Cystic echinococcosis: Analysis of the serological profile related to the risk factors in individuals without ultrasound liver changes living in an endemic area of Tacuarembo, Uruguay. Parasitology 2005, 130, 455-460. [CrossRef] [PubMed]

359. Larrieu, E.J.; Costa, M.T.; del Carpio, M.; Moguillansky, S.; Bianchi, G.; Yadon, Z.E. A case-control study of the risk factors for cystic echinococcosis among the children of Rio Negro province, Argentina. Ann. Trop. Med. Parasitol. 2002, 96, 43-52. [CrossRef] [PubMed]

360. Schantz, P.M.; Wang, H.; Qiu, J.; Liu, F.J.; Saito, E.; Emshoff, A.; Ito, A.; Roberts, J.M.; Delker, C. Echinococcosis on the Tibetan Plateau: Prevalence and risk factors for cystic and alveolar echinococcosis in Tibetan populations in Qinghai Province, China. Parasitology 2003, 127, S109-S120. [CrossRef] [PubMed]

361. Yamamoto, N.; Kishi, R.; Katakura, Y.; Miyake, H. Risk factors for human alveolar echinococcosis: A case-control study in Hokkaido, Japan. Ann. Trop. Med. Parasitol. 2001, 95, 689-696. [CrossRef] [PubMed]

362. Yamamoto, N.; Ohmiya, Y.; Kishi, R.; Miyake, H. Risk factors in serologically diagnosed echinococcosis-A case control study in the Nemuro region of Hokkaido Prefecture. Nihon Koshu Eisei Zasshi 1996, 43, 446-456. [PubMed] 
363. Yang, Y.R.; Sun, T.; Li, Z.; Zhang, J.; Teng, J.; Liu, X.; Liu, R.; Zhao, R.; Jones, M.K.; Wang, Y.; et al. Community surveys and risk factor analysis of human alveolar and cystic echinococcosis in Ningxia Hui Autonomous Region, China. Bull. World Health Organ. 2006, 84, 714-721. [CrossRef] [PubMed]

364. Matthys, B.; Bobieva, M.; Karimova, G.; Mengliboeva, Z.; Jean-Richard, V.; Hoimnazarova, M.; Kurbonova, M.; Lohourignon, L.K.; Utzinger, J.; Wyss, K. Prevalence and risk factors of helminths and intestinal protozoa infections among children from primary schools in western Tajikistan. Parasites Vectors 2011, 4, 195. [CrossRef] [PubMed]

365. Agi, P.I. Comparative helminth infections of man in two rural communities of the Niger Delta, Nigeria. West Afr. J. Med. 1997, 16, 232-236. [PubMed]

366. Agi, P.I. Pattern of infection of intestinal parasites in Sagbama community of the Niger Delta, Nigeria. West Afr. J. Med. 1995, 14, 39-42. [PubMed]

367. Amvrosieva, T.V.; Paklonskaya, N.V.; Biazruchka, A.A.; Kazinetz, O.N.; Bohush, Z.F.; Fisenko, E.G. Enteroviral infection outbreak in the Republic of Belarus: Principal characteristics and phylogenetic analysis of etiological agents. Cent. Eur. J. Public Health 2006, 14, 67-73. [CrossRef] [PubMed]

368. El-Esnawy, N.A.; Ali, M.A.; Bayoumi, F.S.; Abo-El-Khir, A.; Abdel-Wahab, K.S. Waterborne viruses associated with repeated abortion. J. Egypt. Public Health Assoc. 2001, 76, 487-503. [PubMed]

369. Lu, X.D.; Cui, L.L.; Ma, Y.; Zu, R.Q.; Shen, T.; Li, J.Q.; Yao, J.X.; Shan, J.; Xie, Q.; Shi, C.; et al. A viral meningitis outbreak associated with Echo30 in drinking water. Zhonghua Liu Xing Bing Xue Za Zhi 2012, 33, 1067-1071. [PubMed]

370. Sirbu, A.; Pistol, A.; Popovici, F.; Zaharia, A. Considerations in an outbreak of viral acute gastroenteritis, Cisnadie 2009. Bacteriol. Virusol. Parazitol. Epidemiol. 2010, 55, 41-44. [PubMed]

371. Park, S.K.; Park, B.; Ki, M.; Kim, H.; Lee, K.; Jung, C.; Sohn, Y.M.; Choi, S.M.; Kim, D.K.; Lee, D.S.; et al. Transmission of seasonal outbreak of childhood enteroviral aseptic meningitis and hand-foot-mouth disease. J. Korean Med. Sci. 2010, 25, 677-683. [CrossRef] [PubMed]

372. Scarcella, C.; Carasi, S.; Cadoria, F.; Macchi, L.; Pavan, A.; Salamana, M.; Alborali, G.L.; Losio, M.M.; Boni, P.; Lavazza, A.; et al. An outbreak of viral gastroenteritis linked to municipal water supply, Lombardy, Italy, June 2009. Euro Surveill. 2009, 14, 19274. [CrossRef] [PubMed]

373. Jean, J.S.; Guo, H.R.; Chen, S.H.; Liu, C.C.; Chang, W.T.; Yang, Y.J.; Huang, M.C. The association between rainfall rate and occurrence of an enterovirus epidemic due to a contaminated well. J. Appl. Microbiol. 2006, 101, 1224-1231. [CrossRef] [PubMed]

374. McBride, G.B.; Stott, R.; Miller, W.; Bambic, D.; Wuertz, S. Discharge-based QMRA for estimation of public health risks from exposure to stormwater-borne pathogens in recreational waters in the United States. Water Res. 2013, 47, 5282-5297. [CrossRef] [PubMed]

375. Hauri, A.M.; Schimmelpfennig, M.; Walter-Domes, M.; Letz, A.; Diedrich, S.; Lopez-Pila, J.; Schreier, E. An outbreak of viral meningitis associated with a public swimming pond. Epidemiol. Infect. 2005, 133, 291-298. [CrossRef] [PubMed]

376. McLaughlin, J.B.; Gessner, B.D.; Lynn, T.V.; Funk, E.A.; Middaugh, J.P. Association of regulatory issues with an echovirus 18 meningitis outbreak at a children's summer camp in Alaska. Pediatr. Infect. Dis. J. 2004, 23, 875-877. [CrossRef] [PubMed]

377. Amvrosieva, T.V.; Titov, L.P.; Mulders, M.; Hovi, T.; Dyakonova, O.V.; Votyakov, V.I.; Kvacheva, Z.B.; Eremin, V.F.; Sharko, R.M.; Orlova, S.V.; et al. Viral water contamination as the cause of aseptic meningitis outbreak in Belarus. Cent. Eur. J. Public Health 2001, 9, 154-157. [PubMed]

378. Yatsuyanagi, J.; Saito, S.; Miyajima, Y.; Amano, K.; Enomoto, K. Characterization of atypical enteropathogenic Escherichia coli strains harboring the astA gene that were associated with a waterborne outbreak of diarrhea in Japan. J. Clin. Microbiol. 2003, 41, 2033-2039. [CrossRef] [PubMed]

379. Huerta, M.; Grotto, I.; Gdalevich, M.; Mimouni, D.; Gavrieli, B.; Yavzori, M.; Cohen, D.; Shpilberg, O. A waterborne outbreak of gastroenteritis in the Golan Heights due to enterotoxigenic Escherichia coli. Infection 2000, 28, 267-271. [CrossRef] [PubMed]

380. Daniels, N.A.; Neimann, J.; Karpati, A.; Parashar, U.D.; Greene, K.D.; Wells, J.G.; Srivastava, A.; Tauxe, R.V.; Mintz, E.D.; Quick, R. Traveler's diarrhea at sea: Three outbreaks of waterborne enterotoxigenic Escherichia coli on cruise ships. J. Infect. Dis. 2000, 181, 1491-1495. [CrossRef] [PubMed]

381. O’Mahony, M.; Noah, N.D.; Evans, B.; Harper, D.; Rowe, B.; Lowes, J.A.; Pearson, A.; Goode, B. An outbreak of gastroenteritis on a passenger cruise ship. J. Hyg. (Lond.) 1986, 97, 229-236. [CrossRef] [PubMed] 
382. Muramatsu, K.; Wada, M.; Kobayashi, M. An outbreak of well water-associated food-poisoning caused by enterotoxigenic Escherichia coli O159:H20. Kansenshogaku Zasshi 1986, 60, 1-6. [CrossRef] [PubMed]

383. Rosenberg, M.L.; Koplan, J.P.; Wachsmuth, I.K.; Wells, J.G.; Gangarosa, E.J.; Guerrant, R.L.; Sack, D.A. Epidemic diarrhea at Crater Lake from enterotoxigenic Escherichia coli. A large waterborne outbreak. Ann. Intern. Med. 1977, 86, 714-718. [CrossRef] [PubMed]

384. Cortes-Ortiz, I.A.; Rodriguez-Angeles, G.; Moreno-Escobar, E.A.; Tenorio-Lara, J.M.; Torres-Mazadiego, B.P.; Montiel-Vazquez, E. Outbreak caused by Escherichia coli in Chalco, Mexico. Salud Publica Mex. 2002, 44, 297-302. [CrossRef] [PubMed]

385. Rangel, J.M.; Sparling, P.H.; Crowe, C.; Griffin, P.M.; Swerdlow, D.L. Epidemiology of Escherichia coli O157:H7 outbreaks, United States, 1982-2002. Emerg. Infect. Dis. 2005, 11, 603-609. [CrossRef] [PubMed]

386. Hrudey, S.E.; Payment, P.; Huck, P.M.; Gillham, R.W.; Hrudey, E.J. A fatal waterborne disease epidemic in Walkerton, Ontario: Comparison with other waterborne outbreaks in the developed world. Water Sci. Technol. 2003, 47, 7-14. [CrossRef] [PubMed]

387. Samadpour, M.; Stewart, J.; Steingart, K.; Addy, C.; Louderback, J.; McGinn, M.; Ellington, J.; Newman, T. Laboratory investigation of an E. coli O157:H7 outbreak associated with swimming in Battle Ground Lake, Vancouver, Washington. J. Environ. Health 2002, 64, 16-20. [PubMed]

388. Yarze, J.C.; Chase, M.P.E. E. coli O157:H7-Another waterborne outbreak! Am. J. Gastroenterol. 2000, 95, 1096. [CrossRef] [PubMed]

389. Swerdlow, D.L.; Woodruff, B.A.; Brady, R.C.; Griffin, P.M.; Tippen, S.; Donnell, H.D., Jr.; Geldreich, E.; Payne, B.J.; Meyer, A., Jr.; Wells, J.G.; et al. A waterborne outbreak in Missouri of Escherichia coli O157:H7 associated with bloody diarrhea and death. Ann. Intern. Med. 1992, 117, 812-819. [CrossRef] [PubMed]

390. Dev, V.J.; Main, M.; Gould, I. Waterborne outbreak of Escherichia coli O157. Lancet 1991, 337, 1412. [CrossRef]

391. Corso, P.S.; Kramer, M.H.; Blair, K.A.; Addiss, D.G.; Davis, J.P.; Haddix, A.C. Cost of illness in the 1993 waterborne Cryptosporidium outbreak, Milwaukee, Wisconsin. Emerg. Infect. Dis. 2003, 9, 426-431. [CrossRef] [PubMed]

392. Yatsuyanagi, J.; Saito, S.; Kinouchi, Y.; Sato, H.; Morita, M.; Itoh, K. Characteristics of enterotoxigenic Escherichia coli and E. coli harboring enteroaggregative E. coli heat-stable enterotoxin-1 (EAST-1) gene isolated from a water-borne outbreak. Kansenshogaku Zasshi 1996, 70, 215-223. [CrossRef] [PubMed]

393. Chen, J.X.; Chen, M.X.; Ai, L.; Xu, X.N.; Jiao, J.M.; Zhu, T.J.; Su, H.Y.; Zang, W.; Luo, J.J.; Guo, Y.H.; et al. An Outbreak of Human Fascioliasis gigantica in Southwest China. PLoS ONE 2013, 8, e71520. [CrossRef] [PubMed]

394. Ashrafi, K.; Bargues, M.D.; O’Neill, S.; Mas-Coma, S. Fascioliasis: A worldwide parasitic disease of importance in travel medicine. Travel Med. Infect. Dis. 2014, 12, 636-649. [CrossRef] [PubMed]

395. Fox, N.J.; White, P.C.; McClean, C.J.; Marion, G.; Evans, A.; Hutchings, M.R. Predicting impacts of climate change on Fasciola hepatica risk. PLoS ONE 2011, 6, e16126. [CrossRef] [PubMed]

396. Mochankana, M.E.; Robertson, I.D. A retrospective study of the prevalence of bovine fasciolosis at major abattoirs in Botswana. Onderstepoort J. Vet. Res. 2016, 83, a1015. [CrossRef] [PubMed]

397. Selemetas, N.; Ducheyne, E.; Phelan, P.; O’Kiely, P.; Hendrickx, G.; de Waal, T. Spatial analysis and risk mapping of Fasciola hepatica infection in dairy herds in Ireland. Geospat. Health 2015, 9, 281-291. [CrossRef] [PubMed]

398. Selemetas, N.; de Waal, T. Detection of major climatic and environmental predictors of liver fluke exposure risk in Ireland using spatial cluster analysis. Vet. Parasitol. 2015, 209, 242-253. [CrossRef] [PubMed]

399. Ducheyne, E.; Charlier, J.; Vercruysse, J.; Rinaldi, L.; Biggeri, A.; Demeler, J.; Brandt, C.; De Waal, T.; Selemetas, N.; Hoglund, J.; et al. Modelling the spatial distribution of Fasciola hepatica in dairy cattle in Europe. Geospat. Health 2015, 9, 261-270. [CrossRef] [PubMed]

400. Graczyk, T.K.; Gilman, R.H.; Fried, B. Fasciolopsiasis: Is it a controllable food-borne disease? Parasitol. Res. 2001, 87, 80-83. [CrossRef] [PubMed]

401. Bello, J.; Nunez, F.A.; Gonzalez, O.M.; Fernandez, R.; Almirall, P.; Escobedo, A.A. Risk factors for Giardia infection among hospitalized children in Cuba. Ann. Trop. Med. Parasitol. 2011, 105, 57-64. [CrossRef] [PubMed]

402. Teixeira, J.C.; Heller, L.; Barreto, M.L. Giardia duodenalis infection: Risk factors for children living in sub-standard settlements in Brazil. Cad. Saude Publica 2007, 23, 1489-1493. [CrossRef] [PubMed] 
403. Cifuentes, E.; Suarez, L.; Espinosa, M.; Juarez-Figueroa, L.; Martinez-Palomo, A. Risk of Giardia intestinalis infection in children from an artificially recharged groundwater area in Mexico City. Am. J. Trop. Med. Hyg. 2004, 71, 65-70. [CrossRef] [PubMed]

404. Melius, E.J.; Davis, S.I.; Redd, J.T.; Lewin, M.; Herlihy, R.; Henderson, A.; Sobel, J.; Gold, B.; Cheek, J.E. Estimating the prevalence of active Helicobacter pylori infection in a rural community with global positioning system technology-assisted sampling. Epidemiol. Infect. 2013, 141, 472-480. [CrossRef] [PubMed]

405. Hanafi, M.I.; Mohamed, A.M. Helicobacter pylori infection: Seroprevalence and predictors among healthy individuals in Al Madinah, Saudi Arabia. J. Egypt. Public Health Assoc. 2013, 88, 40-45. [CrossRef] [PubMed]

406. Bahrami, A.R.; Rahimi, E.; Ghasemian Safaei, H. Detection of Helicobacter pylori in city water, dental units' water, and bottled mineral water in Isfahan, Iran. Sci. World J. 2013, 2013, 280510. [CrossRef] [PubMed]

407. Queiroz, D.M.; Carneiro, J.G.; Braga-Neto, M.B.; Fialho, A.B.; Fialho, A.M.; Goncalves, M.H.; Rocha, G.A.; Rocha, A.M.; Braga, L.L. Natural history of Helicobacter pylori infection in childhood: Eight-year follow-up cohort study in an urban community in northeast of Brazil. Helicobacter 2012, 17, 23-29. [CrossRef] [PubMed]

408. Khan, A.; Farooqui, A.; Kazmi, S.U. Presence of Helicobacter pylori in drinking water of Karachi, Pakistan. J. Infect. Dev. Ctries. 2012, 6, 251-255. [CrossRef] [PubMed]

409. Travis, P.B.; Goodman, K.J.; O’Rourke, K.M.; Groves, F.D.; Sinha, D.; Nicholas, J.S.; VanDerslice, J.; Lackland, D.; Mena, K.D. The association of drinking water quality and sewage disposal with Helicobacter pylori incidence in infants: The potential role of water-borne transmission. J. Water Health 2010, 8, 192-203. [CrossRef] [PubMed]

410. Strebel, K.; Rolle-Kampczyk, U.; Richter, M.; Kindler, A.; Richter, T.; Schlink, U. A rigorous small area modelling-study for the Helicobacter pylori epidemiology. Sci. Total Environ. 2010, 408, 3931-3942. [CrossRef] [PubMed]

411. Mansour-Ghanaei, F.; Taefeh, N.; Joukar, F.; Besharati, S.; Naghipour, M.; Nassiri, R. Recurrence of Helicobacter pylori infection 1 year after successful eradication: A prospective study in Northern Iran. Med. Sci. Monit. 2010, 16, CR144-CR148. [PubMed]

412. Hestvik, E.; Tylleskar, T.; Kaddu-Mulindwa, D.H.; Ndeezi, G.; Grahnquist, L.; Olafsdottir, E.; Tumwine, J.K. Helicobacter pylori in apparently healthy children aged 0-12 years in urban Kampala, Uganda: A community-based cross sectional survey. BMC Gastroenterol. 2010, 10, 62. [CrossRef] [PubMed]

413. Zhang, L.H.; Zhou, Y.N.; Zhang, Z.Y.; Zhang, F.H.; Li, G.Z.; Li, Q.; Wu, Z.Q.; Ren, B.L.; Zou, S.J.; Wang, J.X. Epidemiological study on status of Helicobacter pylori in children and teenagers in Wuwei city, Gansu province. Zhonghua Yi Xue Za Zhi 2009, 89, 2682-2685. [PubMed]

414. Zaterka, S.; Eisig, J.N.; Chinzon, D.; Rothstein, W. Factors related to Helicobacter pylori prevalence in an adult population in Brazil. Helicobacter 2007, 12, 82-88. [CrossRef] [PubMed]

415. Karita, M.; Teramukai, S.; Matsumoto, S. Risk of Helicobacter pylori transmission from drinking well water is higher than that from infected intrafamilial members in Japan. Dig. Dis. Sci. 2003, 48, 1062-1067. [CrossRef] [PubMed]

416. Bellou, M.; Kokkinos, P.; Vantarakis, A. Shellfish-borne viral outbreaks: A systematic review. Food Environ. Virol. 2013, 5, 13-23. [CrossRef] [PubMed]

417. Tauil Mde, C.; Ferreira, P.M.; Abreu, M.C.; Lima, H.C.; Nobrega, A.A. Hepatite A outbreak in an urban area of Luziania, State of Goias, Brazil, 2009. Rev. Soc. Bras. Med. Trop. 2010, 43, 740-742. [PubMed]

418. Zhang, L.J.; Wang, X.J.; Bai, J.M.; Fang, G.; Liu, L.G.; Zhang, Y.; Fontaine, R.E. An outbreak of hepatitis A in recently vaccinated students from ice snacks made from contaminated well water. Epidemiol. Infect. 2009, 137, 428-433. [CrossRef] [PubMed]

419. Chobe, L.P.; Arankalle, V.A. Investigation of a hepatitis A outbreak from Shimla Himachal Pradesh. Indian J. Med. Res. 2009, 130, 179-184. [PubMed]

420. Sowmyanarayanan, T.V.; Mukhopadhya, A.; Gladstone, B.P.; Sarkar, R.; Kang, G. Investigation of a hepatitis A outbreak in children in an urban slum in Vellore, Tamil Nadu, using geographic information systems. Indian J. Med. Res. 2008, 128, 32-37. [PubMed]

421. Bosch, A.; Sanchez, G.; Le Guyader, F.; Vanaclocha, H.; Haugarreau, L.; Pinto, R.M. Human enteric viruses in Coquina clams associated with a large hepatitis A outbreak. Water Sci. Technol. 2001, 43, 61-65. [CrossRef] [PubMed]

422. Barrimah, E.; Salem, K.A.; Gabal, M.S. An outbreak of hepatitis A associated with treated waste water used for irrigation. J. Egypt. Public Health Assoc. 1999, 74, 227-239. [PubMed] 
423. Poonawagul, U.; Warintrawat, S.; Snitbhan, R.; Kitisriwarapoj, S.; Chaiyakunt, V.; Foy, H.M. Outbreak of hepatitis A in a college traced to contaminated water reservoir in cafeteria. Southeast Asian J. Trop. Med. Public Health 1995, 26, 705-708. [PubMed]

424. Divizia, M.; Gnesivo, C.; Amore Bonapasta, R.; Morace, G.; Pisani, G.; Pana, A. Hepatitis A virus identification in an outbreak by enzymatic amplification. Eur. J. Epidemiol. 1993, 9, 203-208. [CrossRef] [PubMed]

425. Lee, C.S.; Lee, J.H.; Kwon, K.S. Outbreak of hepatitis A in Korean military personnel. Jpn. J. Infect. Dis. 2008, 61, 239-241. [CrossRef] [PubMed]

426. Gharbi-Khelifi, H.; Sdiri, K.; Ferre, V.; Harrath, R.; Berthome, M.; Billaudel, S.; Aouni, M. A 1-year study of the epidemiology of hepatitis A virus in Tunisia. Clin. Microbiol. Infect. 2007, 13, 25-32. [CrossRef] [PubMed]

427. Villar, L.M.; De Paula, V.S.; Gaspar, A.M. Seasonal variation of hepatitis A virus infection in the city of Rio de Janeiro, Brazil. Rev. Inst. Med. Trop. Sao Paulo 2002, 44, 289-292. [CrossRef] [PubMed]

428. Bile, K.; Isse, A.; Mohamud, O.; Allebeck, P.; Nilsson, L.; Norder, H.; Mushahwar, I.K.; Magnius, L.O. Contrasting roles of rivers and wells as sources of drinking water on attack and fatality rates in a hepatitis $\mathrm{E}$ epidemic in Somalia. Am. J. Trop. Med. Hyg. 1994, 51, 466-474. [CrossRef] [PubMed]

429. Abravanel, F.; Lhomme, S.; Dubois, M.; Peron, J.M.; Alric, L.; Kamar, N.; Izopet, J. Hepatitis E virus. Med. Mal. Infect. 2013, 43, 263-270. [CrossRef] [PubMed]

430. Sailaja, B.; Murhekar, M.V.; Hutin, Y.J.; Kuruva, S.; Murthy, S.P.; Reddy, K.S.; Rao, G.M.; Gupte, M.D. Outbreak of waterborne hepatitis E in Hyderabad, India, 2005. Epidemiol. Infect. 2009, 137, 234-240. [CrossRef] [PubMed]

431. Sarguna, P.; Rao, A.; Sudha Ramana, K.N. Outbreak of acute viral hepatitis due to hepatitis E virus in Hyderabad. Indian J. Med. Microbiol. 2007, 25, 378-382. [CrossRef] [PubMed]

432. Shrestha, S.M. Hepatitis E in Nepal. Kathmandu Univ. Med. J. (KUMJ) 2006, 4, 530-544.

433. Leclerc, H.; Schwartzbrod, L.; Dei-Cas, E. Microbial agents associated with waterborne diseases. Crit. Rev. Microbiol. 2002, 28, 371-409. [CrossRef] [PubMed]

434. Corwin, A.L.; Khiem, H.B.; Clayson, E.T.; Pham, K.S.; Vo, T.T.; Vu, T.Y.; Cao, T.T.; Vaughn, D.; Merven, J.; Richie, T.L.; et al. A waterborne outbreak of hepatitis E virus transmission in southwestern Vietnam. Am. J. Trop. Med. Hyg. 1996, 54, 559-562. [CrossRef] [PubMed]

435. Naik, S.R.; Aggarwal, R.; Salunke, P.N.; Mehrotra, N.N. A large waterborne viral hepatitis E epidemic in Kanpur, India. Bull. World Health Organ. 1992, 70, 597-604. [PubMed]

436. Tsega, E.; Krawczynski, K.; Hansson, B.G.; Nordenfelt, E.; Negusse, Y.; Alemu, W.; Bahru, Y. Outbreak of acute hepatitis E virus infection among military personnel in northern Ethiopia. J. Med. Virol. 1991, 34, 232-236. [CrossRef] [PubMed]

437. Struelens, M.J.; Maes, N.; Rost, F.; Deplano, A.; Jacobs, F.; Liesnard, C.; Bornstein, N.; Grimont, F.; Lauwers, S.; McIntyre, M.P.; et al. Genotypic and phenotypic methods for the investigation of a nosocomial Legionella pneumophila outbreak and efficacy of control measures. J. Infect. Dis. 1992, 166, 22-30. [CrossRef] [PubMed]

438. Yiallouros, P.K.; Papadouri, T.; Karaoli, C.; Papamichael, E.; Zeniou, M.; Pieridou-Bagatzouni, D.; Papageorgiou, G.T.; Pissarides, N.; Harrison, T.G.; Hadjidemetriou, A. First outbreak of nosocomial Legionella infection in term neonates caused by a cold mist ultrasonic humidifier. Clin. Infect. Dis. 2013, 57, 48-56. [CrossRef] [PubMed]

439. Ferre, M.R.; Arias, C.; Oliva, J.M.; Pedrol, A.; Garcia, M.; Pellicer, T.; Roura, P.; Dominguez, A. A community outbreak of Legionnaires' disease associated with a cooling tower in Vic and Gurb, Catalonia (Spain) in 2005. Eur. J. Clin. Microbiol. Infect. Dis. 2009, 28, 153-159. [CrossRef] [PubMed]

440. Burnsed, L.J.; Hicks, L.A.; Smithee, L.M.; Fields, B.S.; Bradley, K.K.; Pascoe, N.; Richards, S.M.; Mallonee, S.; Littrell, L.; Benson, R.F.; et al. A large, travel-associated outbreak of legionellosis among hotel guests: Utility of the urine antigen assay in confirming Pontiac fever. Clin. Infect. Dis. 2007, 44, 222-228. [CrossRef] [PubMed]

441. Okada, M.; Kawano, K.; Kura, F.; Amemura-Maekawa, J.; Watanabe, H.; Yagita, K.; Endo, T.; Suzuki, S. The largest outbreak of legionellosis in Japan associated with spa baths: Epidemic curve and environmental investigation. Kansenshogaku Zasshi 2005, 79, 365-374. [CrossRef] [PubMed]

442. Garcia-Fulgueiras, A.; Navarro, C.; Fenoll, D.; Garcia, J.; Gonzalez-Diego, P.; Jimenez-Bunuales, T.; Rodriguez, M.; Lopez, R.; Pacheco, F.; Ruiz, J.; et al. Legionnaires' disease outbreak in Murcia, Spain. Emerg. Infect. Dis. 2003, 9, 915-921. [CrossRef] [PubMed] 
443. Den Boer, J.W.; Yzerman, E.P.; Schellekens, J.; Lettinga, K.D.; Boshuizen, H.C.; Van Steenbergen, J.E.; Bosman, A.; Van den Hof, S.; Van Vliet, H.A.; Peeters, M.F.; et al. A large outbreak of Legionnaires' disease at a flower show, the Netherlands, 1999. Emerg. Infect. Dis. 2002, 8, 37-43. [CrossRef] [PubMed]

444. Fisman, D.N.; Lim, S.; Wellenius, G.A.; Johnson, C.; Britz, P.; Gaskins, M.; Maher, J.; Mittleman, M.A.; Spain, C.V.; Haas, C.N.; et al. It's not the heat, it's the humidity: Wet weather increases legionellosis risk in the greater Philadelphia metropolitan area. J. Infect. Dis. 2005, 192, 2066-2073. [CrossRef] [PubMed]

445. Herrera-Lara, S.; Fernandez-Fabrellas, E.; Cervera-Juan, A.; Blanquer-Olivas, R. Do seasonal changes and climate influence the etiology of community acquired pneumonia? Arch. Bronconeumol. 2013, 49, 140-145. [CrossRef] [PubMed]

446. Garcia-Vidal, C.; Labori, M.; Viasus, D.; Simonetti, A.; Garcia-Somoza, D.; Dorca, J.; Gudiol, F.; Carratala, J. Rainfall is a risk factor for sporadic cases of Legionella pneumophila pneumonia. PLoS ONE 2013, 8, e61036. [CrossRef] [PubMed]

447. Kool, J.L.; Warwick, M.C.; Pruckler, J.M.; Brown, E.W.; Butler, J.C. Outbreak of Legionnaires' disease at a bar after basement flooding. Lancet 1998, 351, 1030. [CrossRef]

448. Cacciapuoti, B.; Ciceroni, L.; Maffei, C.; Di Stanislao, F.; Strusi, P.; Calegari, L.; Lupidi, R.; Scalise, G.; Cagnoni, G.; Renga, G. A waterborne outbreak of leptospirosis. Am. J. Epidemiol. 1987, 126, 535-545. [CrossRef] [PubMed]

449. Stern, E.J.; Galloway, R.; Shadomy, S.V.; Wannemuehler, K.; Atrubin, D.; Blackmore, C.; Wofford, T.; Wilkins, P.P.; Ari, M.D.; Harris, L.; et al. Outbreak of leptospirosis among Adventure Race participants in Florida, 2005. Clin. Infect. Dis. 2010, 50, 843-849. [CrossRef] [PubMed]

450. Chumakov, M.E. Leptospirosis in the Republic of Mordovia. Med. Parazitol. (Mosk) 2004, 45-50.

451. Ramakrishnan, R.; Patel, M.S.; Gupte, M.D.; Manickam, P.; Venkataraghavan, S. An institutional outbreak of leptospirosis in Chennai, South India. J. Commun. Dis. 2003, 35, 1-8. [PubMed]

452. Perra, A.; Servas, V.; Terrier, G.; Postic, D.; Baranton, G.; Andre-Fontaine, G.; Vaillant, V.; Capek, I. Clustered cases of leptospirosis in Rochefort, France, June 2001. Euro Surveill. 2002, 7, 131-136. [CrossRef] [PubMed]

453. Ashford, D.A.; Kaiser, R.M.; Spiegel, R.A.; Perkins, B.A.; Weyant, R.S.; Bragg, S.L.; Plikaytis, B.; Jarquin, C.; De Lose Reyes, J.O.; Amador, J.J. Asymptomatic infection and risk factors for leptospirosis in Nicaragua. Am. J. Trop. Med. Hyg. 2000, 63, 249-254. [CrossRef] [PubMed]

454. Ciceroni, L.; Stepan, E.; Pinto, A.; Pizzocaro, P.; Dettori, G.; Franzin, L.; Lupidi, R.; Mansueto, S.; Manera, A.; Ioli, A.; et al. Epidemiological trend of human leptospirosis in Italy between 1994 and 1996. Eur. J. Epidemiol. 2000, 16, 79-86. [CrossRef] [PubMed]

455. Vanasco, N.B.; Sequeira, G.; Dalla Fontana, M.L.; Fusco, S.; Sequeira, M.D.; Enria, D. Report on a leptospirosis outbreak in the city of Santa Fe, Argentina, March-April 1998. Rev. Panam. Salud Publ. 2000, 7, 35-40. [CrossRef]

456. Corwin, A.; Ryan, A.; Bloys, W.; Thomas, R.; Deniega, B.; Watts, D. A waterborne outbreak of leptospirosis among United States military personnel in Okinawa, Japan. Int. J. Epidemiol. 1990, 19, 743-748. [CrossRef] [PubMed]

457. Radl, C.; Muller, M.; Revilla-Fernandez, S.; Karner-Zuser, S.; de Martin, A.; Schauer, U.; Karner, F.; Stanek, G.; Balcke, P.; Hallas, A.; et al. Outbreak of leptospirosis among triathlon participants in Langau, Austria, 2010. Wien. Klin. Wochenschr. 2011, 123, 751-755. [CrossRef] [PubMed]

458. Sohan, L.; Shyamal, B.; Kumar, T.S.; Malini, M.; Ravi, K.; Venkatesh, V.; Veena, M.; Lal, S. Studies on leptospirosis outbreaks in Peddamandem Mandal of Chittoor district, Andhra Pradesh. J. Commun. Dis. 2008, 40, 127-132. [PubMed]

459. Gaynor, K.; Katz, A.R.; Park, S.Y.; Nakata, M.; Clark, T.A.; Effler, P.V. Leptospirosis on Oahu: An outbreak associated with flooding of a university campus. Am. J. Trop. Med. Hyg. 2007, 76, 882-885. [CrossRef] [PubMed]

460. Narita, M.; Fujitani, S.; Haake, D.A.; Paterson, D.L. Leptospirosis after recreational exposure to water in the Yaeyama islands, Japan. Am. J. Trop. Med. Hyg. 2005, 73, 652-656. [CrossRef] [PubMed]

461. Boland, M.; Sayers, G.; Coleman, T.; Bergin, C.; Sheehan, N.; Creamer, E.; O'Connell, M.; Jones, L.; Zochowski, W. A cluster of leptospirosis cases in canoeists following a competition on the River Liffey. Epidemiol. Infect. 2004, 132, 195-200. [CrossRef] [PubMed]

462. Karande, S.; Bhatt, M.; Kelkar, A.; Kulkarni, M.; De, A.; Varaiya, A. An observational study to detect leptospirosis in Mumbai, India, 2000. Arch. Dis. Child. 2003, 88, 1070-1075. [CrossRef] [PubMed] 
463. Gol'denshtein, Z.A.; Kalashnikov, I.A.; Mkrtchan, M.O.; Popov, V.A.; Pshenichnyi, V.N. Causes of leptospirosis morbidity in Krasnodar region. Zh Mikrobiol. Epidemiol. Immunobiol. 2001, 77-79.

464. Karande, S.; Kulkarni, H.; Kulkarni, M.; De, A.; Varaiya, A. Leptospirosis in children in Mumbai slums. Indian J. Pediatr. 2002, 69, 855-858. [CrossRef] [PubMed]

465. Morgan, J.; Bornstein, S.L.; Karpati, A.M.; Bruce, M.; Bolin, C.A.; Austin, C.C.; Woods, C.W.; Lingappa, J.; Langkop, C.; Davis, B.; et al. Outbreak of leptospirosis among triathlon participants and community residents in Springfield, Illinois, 1998. Clin. Infect. Dis. 2002, 34, 1593-1599. [CrossRef] [PubMed]

466. Trevejo, R.T.; Rigau-Perez, J.G.; Ashford, D.A.; McClure, E.M.; Jarquin-Gonzalez, C.; Amador, J.J.; de los Reyes, J.O.; Gonzalez, A.; Zaki, S.R.; Shieh, W.J.; et al. Epidemic leptospirosis associated with pulmonary hemorrhage-Nicaragua, 1995. J. Infect. Dis. 1998, 178, 1457-1463. [CrossRef] [PubMed]

467. Centers for Disease Control and Prevention. Outbreak of leptospirosis among white-water rafters-Costa Rica, 1996. MMWR Morb. Mortal. Wkly. Rep. 1997, 46, 577-579.

468. Anderson, D.C.; Folland, D.S.; Fox, M.D.; Patton, C.M.; Kaufmann, A.F. Leptospirosis: A common-source outbreak due to leptospires of the grippotyphosa serogroup. Am. J. Epidemiol. 1978, 107, 538-544. [CrossRef] [PubMed]

469. Perez, J.; Brescia, F.; Becam, J.; Mauron, C.; Goarant, C. Rodent abundance dynamics and leptospirosis carriage in an area of hyper-endemicity in New Caledonia. PLoS Negl. Trop. Dis. 2011, 5, e1361. [CrossRef] [PubMed]

470. Robertson, C.; Nelson, T.A.; Stephen, C. Spatial epidemiology of suspected clinical leptospirosis in Sri Lanka. Epidemiol. Infect. 2012, 140, 731-743. [CrossRef] [PubMed]

471. Desai, S.; van Treeck, U.; Lierz, M.; Espelage, W.; Zota, L.; Sarbu, A.; Czerwinski, M.; Sadkowska-Todys, M.; Avdicova, M.; Reetz, J.; et al. Resurgence of field fever in a temperate country: An epidemic of leptospirosis among seasonal strawberry harvesters in Germany in 2007. Clin. Infect. Dis. 2009, 48, 691-697. [CrossRef] [PubMed]

472. Hicks, L.A.; Rose, C.E., Jr.; Fields, B.S.; Drees, M.L.; Engel, J.P.; Jenkins, P.R.; Rouse, B.S.; Blythe, D.; Khalifah, A.P.; Feikin, D.R.; et al. Increased rainfall is associated with increased risk for legionellosis. Epidemiol. Infect. 2007, 135, 811-817. [CrossRef] [PubMed]

473. Lau, C.L.; Watson, C.H.; Lowry, J.H.; David, M.C.; Craig, S.B.; Wynwood, S.J.; Kama, M.; Nilles, E.J. Human Leptospirosis Infection in Fiji: An Eco-epidemiological Approach to Identifying Risk Factors and Environmental Drivers for Transmission. PLoS Negl. Trop. Dis. 2016, 10, e0004405. [CrossRef] [PubMed]

474. Decraene, V.; Lebbad, M.; Botero-Kleiven, S.; Gustavsson, A.M.; Lofdahl, M. First reported foodborne outbreak associated with microsporidia, Sweden, October 2009. Epidemiol. Infect. 2012, 140, 519-527. [CrossRef] [PubMed]

475. Cotte, L.; Rabodonirina, M.; Chapuis, F.; Bailly, F.; Bissuel, F.; Raynal, C.; Gelas, P.; Persat, F.; Piens, M.A.; Trepo, C. Waterborne outbreak of intestinal microsporidiosis in persons with and without human immunodeficiency virus infection. J. Infect. Dis. 1999, 180, 2003-2008. [CrossRef] [PubMed]

476. Hunter, P.R. Waterborne outbreak of microsporidiosis. J. Infect. Dis. 2000, 182, 380-381. [CrossRef] [PubMed]

477. Sengupta, J.; Saha, S.; Khetan, A.; Pal, D.; Gangopadhyay, N.; Banerjee, D. Characteristics of microsporidial keratoconjunctivitis in an eastern Indian cohort: A case series. Indian J. Pathol. Microbiol. 2011, 54, 565-568. [CrossRef] [PubMed]

478. Sharma, S.; Das, S.; Joseph, J.; Vemuganti, G.K.; Murthy, S. Microsporidial keratitis: Need for increased awareness. Surv. Ophthalmol. 2011, 56, 1-22. [CrossRef] [PubMed]

479. Das, S.; Sharma, S.; Sahu, S.K.; Nayak, S.S.; Kar, S. New microbial spectrum of epidemic keratoconjunctivitis: Clinical and laboratory aspects of an outbreak. Br. J. Ophthalmol. 2008, 92, 861-862. [PubMed]

480. Didier, E.S.; Weiss, L.M. Microsporidiosis: Not just in AIDS patients. Curr. Opin. Infect. Dis. 2011, $24,490-495$. [CrossRef] [PubMed]

481. Tu, E.Y.; Joslin, C.E. Microsporidia and Acanthamoeba: The role of emerging corneal pathogens. Eye 2012, 26, 222-227. [CrossRef] [PubMed]

482. Merlani, G.M.; Francioli, P. Established and emerging waterborne nosocomial infections. Curr. Opin. Infect. Dis. 2003, 16, 343-347. [CrossRef] [PubMed]

483. Moraga-McHaley, S.A.; Landen, M.; Krapfl, H.; Sewell, C.M. Hypersensitivity pneumonitis with Mycobacterium avium complex among spa workers. Int. J. Occup. Environ. Health 2013, 19, 55-61. [CrossRef] [PubMed] 
484. Brown-Elliott, B.A.; Wallace, R.J., Jr.; Tichindelean, C.; Sarria, J.C.; McNulty, S.; Vasireddy, R.; Bridge, L.; Mayhall, C.G.; Turenne, C.; Loeffelholz, M. Five-year outbreak of community- and hospital-acquired Mycobacterium porcinum infections related to public water supplies. J. Clin. Microbiol. 2011, 49, 4231-4238. [CrossRef] [PubMed]

485. Yuan, J.; Liu, Y.; Yang, Z.; Cai, Y.; Deng, Z.; Qin, P.; Li, T.; Dong, Z.; Yan, Z.; Zhou, D.; et al. Mycobacterium abscessus post-injection abscesses from extrinsic contamination of multiple-dose bottles of normal saline in a rural clinic. Int. J. Infect. Dis. 2009, 13, 537-542. [CrossRef] [PubMed]

486. Livni, G.; Yaniv, I.; Samra, Z.; Kaufman, L.; Solter, E.; Ashkenazi, S.; Levy, I. Outbreak of Mycobacterium mucogenicum bacteraemia due to contaminated water supply in a paediatric haematology-oncology department. J. Hosp. Infect. 2008, 70, 253-258. [CrossRef] [PubMed]

487. Kline, S.; Cameron, S.; Streifel, A.; Yakrus, M.A.; Kairis, F.; Peacock, K.; Besser, J.; Cooksey, R.C. An outbreak of bacteremias associated with Mycobacterium mucogenicum in a hospital water supply. Infect. Control Hosp. Epidemiol. 2004, 25, 1042-1049. [CrossRef] [PubMed]

488. Falkinham, J.O., 3rd. Mycobacterial aerosols and respiratory disease. Emerg. Infect. Dis. 2003, 9, $763-767$. [CrossRef] [PubMed]

489. Winthrop, K.L.; Abrams, M.; Yakrus, M.; Schwartz, I.; Ely, J.; Gillies, D.; Vugia, D.J. An outbreak of mycobacterial furunculosis associated with footbaths at a nail salon. N. Engl. J. Med. 2002, 346, 1366-1371. [CrossRef] [PubMed]

490. Astagneau, P.; Desplaces, N.; Vincent, V.; Chicheportiche, V.; Botherel, A.; Maugat, S.; Lebascle, K.; Leonard, P.; Desenclos, J.; Grosset, J.; et al. Mycobacterium xenopi spinal infections after discovertebral surgery: Investigation and screening of a large outbreak. Lancet 2001, 358, 747-751. [CrossRef]

491. Wenger, J.D.; Spika, J.S.; Smithwick, R.W.; Pryor, V.; Dodson, D.W.; Carden, G.A.; Klontz, K.C. Outbreak of Mycobacterium chelonae infection associated with use of jet injectors. JAMA 1990, 264, 373-376. [CrossRef] [PubMed]

492. Bolan, G.; Reingold, A.L.; Carson, L.A.; Silcox, V.A.; Woodley, C.L.; Hayes, P.S.; Hightower, A.W.; McFarland, L.; Brown, J.W., 3rd; Petersen, N.J.; et al. Infections with Mycobacterium chelonei in patients receiving dialysis and using processed hemodialyzers. J. Infect. Dis. 1985, 152, 1013-1019. [CrossRef] [PubMed]

493. Apisarnthanarak, A.; Warren, D.K.; Glen Mayhall, C. Healthcare-associated infections and their prevention after extensive flooding. Curr. Opin. Infect. Dis. 2013, 26, 359-365. [CrossRef] [PubMed]

494. Falkinham, J.O., 3rd; Iseman, M.D.; de Haas, P.; van Soolingen, D. Mycobacterium avium in a shower linked to pulmonary disease. J. Water Health 2008, 6, 209-213. [CrossRef] [PubMed]

495. Yagupsky, P.; Menegus, M.A. Waterborne Mycobacterium avium infection. JAMA 1989, 261, 994. [CrossRef] [PubMed]

496. Marciano-Cabral, F. Biology of Naegleria spp. Microbiol. Rev. 1988, 52, 114-133. [PubMed]

497. Levy, D.A.; Bens, M.S.; Craun, G.F.; Calderon, R.L.; Herwaldt, B.L. Surveillance for waterborne-disease outbreaks-United States, 1995-1996. MMWR CDC Surveill. Summ. 1998, 47, 1-34. [PubMed]

498. Diaz, J. Seasonal primary amebic meningoencephalitis (PAM) in the south: Summertime is PAM time. J. La. State Med. Soc. 2012, 164, 148-150. [PubMed]

499. Weeks, J.; Mooney, P.; Lipscomb, G.; Pearson, J.M.; Ong, A.; Singh, S. An unexpected finding on gastroscopy: Gastro-gastric fistula with Helicobacter pylori and Giardia lamblia. Endoscopy 2013, 45 (Suppl. 2). [CrossRef] [PubMed]

500. Zhou, X.; Li, H.; Sun, L.; Mo, Y.; Chen, S.; Wu, X.; Liang, J.; Zheng, H.; Ke, C.; Varma, J.K.; et al. Epidemiological and molecular analysis of a waterborne outbreak of norovirus GII.4. Epidemiol. Infect. 2012, 140, 2282-2289. [CrossRef] [PubMed]

501. Nenonen, N.P.; Hannoun, C.; Larsson, C.U.; Bergstrom, T. Marked genomic diversity of norovirus genogroup I strains in a waterborne outbreak. Appl. Environ. Microbiol. 2012, 78, 1846-1852. [CrossRef] [PubMed]

502. Matthews, J.E.; Dickey, B.W.; Miller, R.D.; Felzer, J.R.; Dawson, B.P.; Lee, A.S.; Rocks, J.J.; Kiel, J.; Montes, J.S.; Moe, C.L.; et al. The epidemiology of published norovirus outbreaks: A review of risk factors associated with attack rate and genogroup. Epidemiol. Infect. 2012, 140, 1161-1172. [CrossRef] [PubMed]

503. Arvelo, W.; Sosa, S.M.; Juliao, P.; Lopez, M.R.; Estevez, A.; Lopez, B.; Morales-Betoulle, M.E.; Gonzalez, M.; Gregoricus, N.A.; Hall, A.J.; et al. Norovirus outbreak of probable waterborne transmission with high attack rate in a Guatemalan resort. J. Clin. Virol. 2012, 55, 8-11. [CrossRef] [PubMed] 
504. Riera-Montes, M.; Brus Sjolander, K.; Allestam, G.; Hallin, E.; Hedlund, K.O.; Lofdahl, M. Waterborne norovirus outbreak in a municipal drinking-water supply in Sweden. Epidemiol. Infect. 2011, 139, 1928-1935. [CrossRef] [PubMed]

505. Koh, S.J.; Cho, H.G.; Kim, B.H.; Choi, B.Y. An outbreak of gastroenteritis caused by norovirus-contaminated groundwater at a waterpark in Korea. J. Korean Med. Sci. 2011, 26, 28-32. [CrossRef] [PubMed]

506. Breitenmoser, A.; Fretz, R.; Schmid, J.; Besl, A.; Etter, R. Outbreak of acute gastroenteritis due to a washwater-contaminated water supply, Switzerland, 2008. J. Water Health 2011, 9, 569-576. [CrossRef] [PubMed]

507. Werber, D.; Lausevic, D.; Mugosa, B.; Vratnica, Z.; Ivanovic-Nikolic, L.; Zizic, L.; Alexandre-Bird, A.; Fiore, L.; Ruggeri, F.M.; Di Bartolo, I.; et al. Massive outbreak of viral gastroenteritis associated with consumption of municipal drinking water in a European capital city. Epidemiol. Infect. 2009, 137, 1713-1720. [CrossRef] [PubMed]

508. Podewils, L.J.; Zanardi Blevins, L.; Hagenbuch, M.; Itani, D.; Burns, A.; Otto, C.; Blanton, L.; Adams, S.; Monroe, S.S.; Beach, M.J.; et al. Outbreak of norovirus illness associated with a swimming pool. Epidemiol. Infect. 2007, 135, 827-833. [CrossRef] [PubMed]

509. Doyle, A.; Barataud, D.; Gallay, A.; Thiolet, J.M.; Le Guyaguer, S.; Kohli, E.; Vaillant, V. Norovirus foodborne outbreaks associated with the consumption of oysters from the Etang de Thau, France, December 2002. Euro Surveill. 2004, 9, 24-26. [CrossRef] [PubMed]

510. Kramer, M.H.; Herwaldt, B.L.; Craun, G.F.; Calderon, R.L.; Juranek, D.D. Surveillance for waterborne-disease outbreaks-United States, 1993-1994. MMWR CDC Surveill. Summ. 1996, 45, 1-33. [PubMed]

511. Moore, A.C.; Herwaldt, B.L.; Craun, G.F.; Calderon, R.L.; Highsmith, A.K.; Juranek, D.D. Surveillance for waterborne disease outbreaks-United States, 1991-1992. MMWR CDC Surveill. Summ. 1993, 42, 1-22. [PubMed]

512. Levine, W.C.; Stephenson, W.T.; Craun, G.F. Waterborne disease outbreaks, 1986-1988. MMWR CDC Surveill. Summ. 1990, 39, 1-13. [CrossRef] [PubMed]

513. Tsukamoto, T.; Kinoshita, Y.; Shimada, T.; Sakazaki, R. Two epidemics of diarrhoeal disease possibly caused by Plesiomonas shigelloides. J. Hyg. (Lond.) 1978, 80, 275-280. [CrossRef] [PubMed]

514. Van Asperen, I.A.; de Rover, C.M.; Schijven, J.F.; Oetomo, S.B.; Schellekens, J.F.; van Leeuwen, N.J.; Colle, C.; Havelaar, A.H.; Kromhout, D.; Sprenger, M.W. Risk of otitis externa after swimming in recreational fresh water lakes containing Pseudomonas aeruginosa. BMJ 1995, 311, 1407-1410. [CrossRef] [PubMed]

515. Arseculeratne, S.N.; Sumathipala, S.; Eriyagama, N.B. Patterns of rhinosporidiosis in Sri Lanka: Comparison with international data. Southeast Asian J. Trop. Med. Public Health 2010, 41, 175-191. [PubMed]

516. Radovanovic, Z.; Vukovic, Z.; Jankovic, S. Attitude of involved epidemiologists toward the first European outbreak of rhinosporidiosis. Eur. J. Epidemiol. 1997, 13, 157-160. [CrossRef] [PubMed]

517. Vukovic, Z.; Bobic-Radovanovic, A.; Latkovic, Z.; Radovanovic, Z. An epidemiological investigation of the first outbreak of rhinosporidiosis in Europe. J. Trop. Med. Hyg. 1995, 98, 333-337. [PubMed]

518. Kozlica, J.; Claudet, A.L.; Solomon, D.; Dunn, J.R.; Carpenter, L.R. Waterborne outbreak of Salmonella I 4,[5],12:i. Foodborne Pathog. Dis. 2010, 7, 1431-1433. [CrossRef] [PubMed]

519. Gallay, A.; De Valk, H.; Cournot, M.; Ladeuil, B.; Hemery, C.; Castor, C.; Bon, F.; Megraud, F.; Le Cann, P.; Desenclos, J.C.; et al. A large multi-pathogen waterborne community outbreak linked to faecal contamination of a groundwater system, France, 2000. Clin. Microbiol. Infect. 2006, 12, 561-570. [CrossRef] [PubMed]

520. Koroglu, M.; Yakupogullari, Y.; Otlu, B.; Ozturk, S.; Ozden, M.; Ozer, A.; Sener, K.; Durmaz, R. A waterborne outbreak of epidemic diarrhea due to group A rotavirus in Malatya, Turkey. New Microbiol. 2011, 34, 17-24. [PubMed]

521. Siqueira, A.A.; Santelli, A.C.; Alencar, L.R., Jr.; Dantas, M.P.; Dimech, C.P.; Carmo, G.M.; Santos, D.A.; Alves, R.M.; Lucena, M.B.; Morais, M.; et al. Outbreak of acute gastroenteritis in young children with death due to rotavirus genotype G9 in Rio Branco, Brazilian Amazon region, 2005. Int. J. Infect. Dis. 2010, 14, e898-e903. [CrossRef] [PubMed]

522. Timenetsky, M.C.; Gouvea, V.; Santos, N.; Alge, M.E.; Kisiellius, J.J.; Carmona, R.C. Outbreak of severe gastroenteritis in adults and children associated with type G2 rotavirus. Study Group on Diarrhea of the Instituto Adolfo Lutz. J. Diarrhoeal Dis. Res. 1996, 14, 71-74. [PubMed] 
523. Hopkins, R.S.; Gaspard, G.B.; Williams, F.P., Jr.; Karlin, R.J.; Cukor, G.; Blacklow, N.R. A community waterborne gastroenteritis outbreak: Evidence for rotavirus as the agent. Am. J. Public Health 1984, 74, 263-265. [CrossRef] [PubMed]

524. Sutmoller, F.; Azeredo, R.S.; Lacerda, M.D.; Barth, O.M.; Pereira, H.G.; Hoffer, E.; Schatzmayr, H.G. An outbreak of gastroenteritis caused by both rotavirus and Shigella sonnei in a private school in Rio de Janeiro. J. Hyg. (Lond.) 1982, 88, 285-293. [CrossRef] [PubMed]

525. Zamotin, B.A.; Libiiainen, L.T.; Bortnik, F.L.; Chernitskaia, E.P.; Enina, Z.I. Water-borne outbreaks of rotavirus infections. Zh Mikrobiol. Epidemiol. Immunobiol. 1981, 100-102.

526. Gouvea, V.S.; Dias, G.S.; Aguiar, E.A.; Pedro, A.R.; Fichman, E.R.; Chinem, E.S.; Gomes, S.P.; Domingues, A.L. Acute gastroenteritis in a pediatric hospital in rio de janeiro in pre- and post-rotavirus vaccination settings. Open Virol. J. 2009, 3, 26-30. [CrossRef] [PubMed]

527. Cervia, J.S.; Farber, B.; Armellino, D.; Klocke, J.; Bayer, R.L.; McAlister, M.; Stanchfield, I.; Canonica, F.P.; Ortolano, G.A. Point-of-use water filtration reduces healthcare-associated infections in bone marrow transplant recipients. Transpl. Infect. Dis. 2010, 12, 238-241. [CrossRef] [PubMed]

528. Dignani, M.C.; Grazziutti, M.; Anaissie, E. Stenotrophomonas maltophilia infections. Semin. Respir. Crit. Care Med. 2003, 24, 89-98. [CrossRef] [PubMed]

529. Sakhnini, E.; Weissmann, A.; Oren, I. Fulminant Stenotrophomonas maltophilia soft tissue infection in immunocompromised patients: An outbreak transmitted via tap water. Am. J. Med. Sci. 2002, 323, 269-272. [CrossRef] [PubMed]

530. Verweij, P.E.; Meis, J.F.; Christmann, V.; Van der Bor, M.; Melchers, W.J.; Hilderink, B.G.; Voss, A. Nosocomial outbreak of colonization and infection with Stenotrophomonas maltophilia in preterm infants associated with contaminated tap water. Epidemiol. Infect. 1998, 120, 251-256. [CrossRef] [PubMed]

531. Weber, D.J.; Rutala, W.A.; Blanchet, C.N.; Jordan, M.; Gergen, M.F. Faucet aerators: A source of patient colonization with Stenotrophomonas maltophilia. Am. J. Infect. Control 1999, 27, 59-63. [CrossRef]

532. Ailes, E.; Budge, P.; Shankar, M.; Collier, S.; Brinton, W.; Cronquist, A.; Chen, M.; Thornton, A.; Beach, M.J.; Brunkard, J.M. Economic and health impacts associated with a Salmonella Typhimurium drinking water outbreak-Alamosa, CO, 2008. PLoS ONE 2013, 8, e57439. [CrossRef] [PubMed]

533. Anita, S.; Amir, K.M.; Fadzilah, K.; Ahamad, J.; Noorhaida, U.; Marina, K.; Paid, M.Y.; Hanif, Z. Risk factors for typhoid outbreak in Sungai Congkak Recreational Park, Selangor 2009. Med. J. Malays. 2012, 67, 12-16.

534. Bayram, Y.; Guducuoglu, H.; Otlu, B.; Aypak, C.; Gursoy, N.C.; Uluc, H.; Berktas, M. Epidemiological characteristics and molecular typing of Salmonella enterica serovar Typhi during a waterborne outbreak in Eastern Anatolia. Ann. Trop. Med. Parasitol. 2011, 105, 359-365. [CrossRef] [PubMed]

535. Bhunia, R.; Hutin, Y.; Ramakrishnan, R.; Pal, N.; Sen, T.; Murhekar, M. A typhoid fever outbreak in a slum of South Dumdum municipality, West Bengal, India, 2007: Evidence for foodborne and waterborne transmission. BMC Public Health 2009, 9, 115. [CrossRef] [PubMed]

536. Farooqui, A.; Khan, A.; Kazmi, S.U. Investigation of a community outbreak of typhoid fever associated with drinking water. BMC Public Health 2009, 9, 476. [CrossRef] [PubMed]

537. Franklin, L.J.; Fielding, J.E.; Gregory, J.; Gullan, L.; Lightfoot, D.; Poznanski, S.Y.; Vally, H. An outbreak of Salmonella Typhimurium 9 at a school camp linked to contamination of rainwater tanks. Epidemiol. Infect. 2009, 137, 434-440. [CrossRef] [PubMed]

538. King, C.C.; Chen, C.J.; You, S.L.; Chuang, Y.C.; Huang, H.H.; Tsai, W.C. Community-wide epidemiological investigation of a typhoid outbreak in a rural township in Taiwan, Republic of China. Int. J. Epidemiol. 1989, 18, 254-260. [CrossRef] [PubMed]

539. Molinero, M.E.; Fernandez, I.; Garcia-Calabuig, M.A.; Peiro, E. Investigation of a water-borne Salmonella ohio outbreak. Enferm. Infecc. Microbiol. Clin. 1998, 16, 230-232. [PubMed]

540. Muramatsu, K.; Nishizawa, S. An outbreak of municipal water-associated food poisoning caused by Salmonella enteritidis. Kansenshogaku Zasshi 1992, 66, 754-760. [CrossRef] [PubMed]

541. Nishina, T.; Shiozawa, K.; Hayashi, M.; Akiyama, M.; Sahara, K.; Miwa, N.; Nakatsugawa, S.; Murakami, M.; Nakamura, A. A waterborne outbreak of typhoid fever associated with a small drinking water supply system in Fuji city. Kansenshogaku Zasshi 1989, 63, 240-247. [CrossRef] [PubMed]

542. Swaddiwudhipong, W.; Kanlayanaphotporn, J. A common-source water-borne outbreak of multidrug-resistant typhoid fever in a rural Thai community. J. Med. Assoc. Thai. 2001, 84, 1513-1517. [PubMed] 
543. Taylor, R.; Sloan, D.; Cooper, T.; Morton, B.; Hunter, I. A waterborne outbreak of Salmonella Saintpaul. Commun. Dis. Intell. 2000, 24, 336-340. [PubMed]

544. Usera, M.A.; Echeita, A.; Aladuena, A.; Alvarez, J.; Carreno, C.; Orcau, A.; Planas, C. Investigation of an outbreak of water-borne typhoid fever in Catalonia in 1994. Enferm. Infecc. Microbiol. Clin. 1995, 13, 450-454. [PubMed]

545. Yang, H.H.; Gong, J.; Zhang, J.; Wang, M.L.; Yang, J.; Wu, G.Z.; Quan, W.L.; Gong, H.M.; Szu, S.C. An outbreak of Salmonella Paratyphi A in a boarding school: A community-acquired enteric fever and carriage investigation. Epidemiol. Infect. 2010, 138, 1765-1774. [CrossRef] [PubMed]

546. Fleury, M.; Charron, D.F.; Holt, J.D.; Allen, O.B.; Maarouf, A.R. A time series analysis of the relationship of ambient temperature and common bacterial enteric infections in two Canadian provinces. Int. J. Biometeorol. 2006, 50, 385-391. [CrossRef] [PubMed]

547. Karkey, A.; Jombart, T.; Walker, A.W.; Thompson, C.N.; Torres, A.; Dongol, S.; Tran Vu Thieu, N.; Pham Thanh, D.; Tran Thi Ngoc, D.; Voong Vinh, P.; et al. The Ecological Dynamics of Fecal Contamination and Salmonella Typhi and Salmonella Paratyphi A in Municipal Kathmandu Drinking Water. PLoS Negl. Trop. Dis. 2016, 10, e0004346. [CrossRef] [PubMed]

548. Kim, S. Salmonella serovars from foodborne and waterborne diseases in Korea, 1998-2007: Total isolates decreasing versus rare serovars emerging. J. Korean Med. Sci. 2010, 25, 1693-1699. [CrossRef] [PubMed]

549. Iseri, L.; Bayraktar, M.R.; Aktas, E.; Durmaz, R. Investigation of an outbreak of Salmonella Typhi in Battalgazi district, Malatya-Turkey. Braz. J. Microbiol. 2009, 40, 170-173. [CrossRef] [PubMed]

550. Karkey, A.; Arjyal, A.; Anders, K.L.; Boni, M.F.; Dongol, S.; Koirala, S.; My, P.V.; Nga, T.V.; Clements, A.C.; Holt, K.E.; et al. The burden and characteristics of enteric fever at a healthcare facility in a densely populated area of Kathmandu. PLoS ONE 2010, 5, e13988. [CrossRef] [PubMed]

551. Krol-Turminska, K.; Olender, A. Human infections caused by free-living amoebae. Ann. Agric. Environ. Med. 2017, 24, 254-260. [CrossRef] [PubMed]

552. Gelman, B.B.; Popov, V.; Chaljub, G.; Nader, R.; Rauf, S.J.; Nauta, H.W.; Visvesvara, G.S. Neuropathological and ultrastructural features of amebic encephalitis caused by Sappinia diploidea. J. Neuropathol. Exp. Neurol. 2003, 62, 990-998. [CrossRef] [PubMed]

553. Makhija, M. Histological identification of muscular sarcocystis: A report of two cases. Indian J. Pathol. Microbiol. 2012, 55, 552-554. [CrossRef] [PubMed]

554. Nichols, G.L. Food-borne protozoa. Br. Med. Bull. 2000, 56, 209-235. [CrossRef] [PubMed]

555. Remais, J. Modelling environmentally-mediated infectious diseases of humans: Transmission dynamics of schistosomiasis in China. Adv. Exp. Med. Boil. 2010, 673, 79-98.

556. Barbosa, C.S.; Domingues, A.L.; Abath, F.; Montenegro, S.M.; Guida, U.; Carneiro, J.; Tabosa, B.; Moraes, C.N.; Spinelli, V. An outbreak of acute schistosomiasis at Porto de Galinhas beach, Pernambuco, Brazil. Cad. Saude Publica 2001, 17, 725-728. [CrossRef] [PubMed]

557. Bavia, M.E.; Hale, L.F.; Malone, J.B.; Braud, D.H.; Shane, S.M. Geographic information systems and the environmental risk of schistosomiasis in Bahia, Brazil. Am. J. Trop. Med. Hyg. 1999, 60, 566-572. [CrossRef] [PubMed]

558. Ekpo, U.F.; Mafiana, C.F.; Adeofun, C.O.; Solarin, A.R.; Idowu, A.B. Geographical information system and predictive risk maps of urinary schistosomiasis in Ogun State, Nigeria. BMC Infect. Dis. 2008, 8, 74. [CrossRef] [PubMed]

559. Kabatereine, N.B.; Brooker, S.; Tukahebwa, E.M.; Kazibwe, F.; Onapa, A.W. Epidemiology and geography of Schistosoma mansoni in Uganda: Implications for planning control. Trop. Med. Int. Health 2004, 9, 372-380. [CrossRef] [PubMed]

560. Raso, G.; Matthys, B.; N'Goran, E.K.; Tanner, M.; Vounatsou, P.; Utzinger, J. Spatial risk prediction and mapping of Schistosoma mansoni infections among schoolchildren living in western Cote d'Ivoire. Parasitology 2005, 131, 97-108. [CrossRef] [PubMed]

561. Remais, J.; Liang, S.; Spear, R.C. Coupling hydrologic and infectious disease models to explain regional differences in schistosomiasis transmission in southwestern China. Environ. Sci. Technol. 2008, 42, 2643-2649. [CrossRef] [PubMed]

562. Remais, J.; Zhong, B.; Carlton, E.J.; Spear, R.C. Model approaches for estimating the influence of time-varying socio-environmental factors on macroparasite transmission in two endemic regions. Epidemics 2009, 1, 213-220. [CrossRef] [PubMed] 
563. Yang, J.; Zhao, Z.; Li, Y.; Krewski, D.; Wen, S.W. A multi-level analysis of risk factors for Schistosoma japonicum infection in China. Int. J. Infect. Dis. 2009, 13, e407-e412. [CrossRef] [PubMed]

564. Visser, L.G.; Polderman, A.M.; Stuiver, P.C. Outbreak of schistosomiasis among travelers returning from Mali, West Africa. Clin. Infect. Dis. 1995, 20, 280-285. [CrossRef] [PubMed]

565. Blach, O.; Rai, B.; Oates, K.; Franklin, G.; Bramwell, S. An outbreak of schistosomiasis in travellers returning from endemic areas: The importance of rigorous tracing in peer groups exposed to risk of infection. J. Public Health 2012, 34, 32-36. [CrossRef] [PubMed]

566. Lin, C.Y.; Fan, P.C.; Wu, C.C. An outbreak of schistosomiasis japonica in Taiwan. Zhonghua Minguo Wei Sheng Wu Ji Mian Yi Xue Za Zhi 1988, 21, 243-246. [PubMed]

567. Chunge, C.N.; Chunge, R.N.; Masinde, M.S.; Atinga, J.N. An outbreak of acute schistosomiasis following a church retreat to Mwanza, Tanzania, 2008. J. Travel Med. 2011, 18, 408-410. [CrossRef] [PubMed]

568. Enk, M.J.; Amorim, A.; Schall, V.T. Acute schistosomiasis outbreak in the metropolitan area of Belo Horizonte, Minas Gerais: Alert about the risk of unnoticed transmission increased by growing rural tourism. Mem. Inst. Oswaldo Cruz 2003, 98, 745-750. [CrossRef] [PubMed]

569. Talla, I.; Kongs, A.; Verle, P.; Belot, J.; Sarr, S.; Coll, A.M. Outbreak of intestinal schistosomiasis in the Senegal River Basin. Ann. Soc. Belg. Med. Trop. 1990, 70, 173-180. [PubMed]

570. Saeed, A.A.; Magzoub, M. An outbreak of Schistosoma mansoni infection in a European community in Darfur, Western Sudan. Ann. Trop. Med. Parasitol. 1974, 68, 405-413. [CrossRef] [PubMed]

571. Sayasone, S.; Rasphone, O.; Vanmany, M.; Vounatsou, P.; Utzinger, J.; Tanner, M.; Akkhavong, K.; Hatz, C.; Odermatt, P. Severe morbidity due to Opisthorchis viverrini and Schistosoma mekongi infection in Lao People's Democratic Republic. Clin. Infect. Dis. 2012, 55, e54-e57. [CrossRef] [PubMed]

572. Sinuon, M.; Tsuyuoka, R.; Socheat, D.; Odermatt, P.; Ohmae, H.; Matsuda, H.; Montresor, A.; Palmer, K. Control of Schistosoma mekongi in Cambodia: Results of eight years of control activities in the two endemic provinces. Trans. R. Soc. Trop. Med. Hyg. 2007, 101, 34-39. [CrossRef] [PubMed]

573. Urbani, C.; Sinoun, M.; Socheat, D.; Pholsena, K.; Strandgaard, H.; Odermatt, P.; Hatz, C. Epidemiology and control of mekongi schistosomiasis. Acta Trop. 2002, 82, 157-168. [CrossRef]

574. Attwood, S.W. Schistosomiasis in the Mekong region: Epidemiology and phylogeography. Adv. Parasitol. 2001, 50, 87-152. [PubMed]

575. Kullavanijaya, P.; Wongwaisayawan, H. Outbreak of cercarial dermatitis in Thailand. Int. J. Dermatol. 1993, 32, 113-115. [CrossRef] [PubMed]

576. Bracaglia, G.; Ranno, S.; Mancinelli, L.; Santoro, M.; Cerroni, L.; Massone, C.; Sangueza, O.; Bravo, F.G.; Diociaiuti, A.; Nicastri, E.; et al. A waterborn zoonotic helminthiase in an Italian diver: A case report of a cutaneous Sparganum infection and a review of European cases. Pathog. Glob. Health 2015, 109, 383-386. [CrossRef] [PubMed]

577. Wiwanitkit, V. A review of human sparganosis in Thailand. Int. J. Infect. Dis. 2005, 9, 312-316. [CrossRef] [PubMed]

578. Pampiglione, S.; Fioravanti, M.L.; Rivasi, F. Human sparganosis in Italy. Case report and review of the European cases. APMIS 2003, 111, 349-354. [CrossRef] [PubMed]

579. Chang, J.H.; Lin, O.S.; Yeh, K.T. Subcutaneous sparganosis-A case report and a review of human sparganosis in Taiwan. Kaohsiung J. Med. Sci. 1999, 15, 567-571. [PubMed]

580. Ma, Q.; Xu, X.; Luo, M.; Wang, J.; Yang, C.; Hu, X.; Liang, B.; Wu, F.; Yang, X.; Wang, J.; et al. A Waterborne Outbreak of Shigella sonnei with Resistance to Azithromycin and Third-Generation Cephalosporins in China in 2015. Antimicrob. Agents Chemother. 2017, 61. [CrossRef] [PubMed]

581. Godoy, P.; Bartolome, R.; Torres, J.; Espinet, L.; Escobar, A.; Nuin, C.; Dominguez, A. Waterborne outbreak of Shigella sonnei caused by consumption of public supply water. Gac. Sanit. 2011, 25, 363-367. [CrossRef] [PubMed]

582. Arias, C.; Sala, M.R.; Dominguez, A.; Bartolome, R.; Benavente, A.; Veciana, P.; Pedrol, A.; Hoyo, G.; Outbreak Working, G. Waterborne epidemic outbreak of Shigella sonnei gastroenteritis in Santa Maria de Palautordera, Catalonia, Spain. Epidemiol. Infect. 2006, 134, 598-604. [CrossRef] [PubMed]

583. Alamanos, Y.; Maipa, V.; Levidiotou, S.; Gessouli, E. A community waterborne outbreak of gastro-enteritis attributed to Shigella sonnei. Epidemiol. Infect. 2000, 125, 499-503. [CrossRef] [PubMed]

584. Sergevnin, V.I.; Sarmometov, E.V.; Skovorodin, A.N. Waterborne outbreaks of Sonne dysentery are not myth but reality. Zh Mikrobiol. Epidemiol. Immunobiol. 1999, 112-113. 
585. Vaudaux, J.D.; Muccioli, C.; James, E.R.; Silveira, C.; Magargal, S.L.; Jung, C.; Dubey, J.P.; Jones, J.L.; Doymaz, M.Z.; Bruckner, D.A.; et al. Identification of an atypical strain of toxoplasma gondii as the cause of a waterborne outbreak of toxoplasmosis in Santa Isabel do Ivai, Brazil. J. Infect. Dis. 2010, 202, 1226-1233. [CrossRef] [PubMed]

586. Balasundaram, M.B.; Andavar, R.; Palaniswamy, M.; Venkatapathy, N. Outbreak of acquired ocular toxoplasmosis involving 248 patients. Arch. Ophthalmol. 2010, 128, 28-32. [CrossRef] [PubMed]

587. De Moura, L.; Bahia-Oliveira, L.M.; Wada, M.Y.; Jones, J.L.; Tuboi, S.H.; Carmo, E.H.; Ramalho, W.M.; Camargo, N.J.; Trevisan, R.; Graca, R.M.; et al. Waterborne toxoplasmosis, Brazil, from field to gene. Emerg. Infect. Dis. 2006, 12, 326-329. [CrossRef] [PubMed]

588. Heukelbach, J.; Meyer-Cirkel, V.; Moura, R.C.; Gomide, M.; Queiroz, J.A.; Saweljew, P.; Liesenfeld, O. Waterborne toxoplasmosis, northeastern Brazil. Emerg. Infect. Dis. 2007, 13, 287-289. [CrossRef] [PubMed]

589. Palanisamy, M.; Madhavan, B.; Balasundaram, M.B.; Andavar, R.; Venkatapathy, N. Outbreak of ocular toxoplasmosis in Coimbatore, India. Indian J. Ophthalmol. 2006, 54, 129-131. [CrossRef] [PubMed]

590. Bowie, W.R.; King, A.S.; Werker, D.H.; Isaac-Renton, J.L.; Bell, A.; Eng, S.B.; Marion, S.A. Outbreak of toxoplasmosis associated with municipal drinking water. The BC Toxoplasma Investigation Team. Lancet 1997, 350, 173-177. [CrossRef]

591. Eng, S.B.; Werker, D.H.; King, A.S.; Marion, S.A.; Bell, A.; Issac-Renton, J.L.; Irwin, G.S.; Bowie, W.R. Computer-generated dot maps as an epidemiologic tool: Investigating an outbreak of toxoplasmosis. Emerg. Infect. Dis. 1999, 5, 815-819. [CrossRef] [PubMed]

592. Caron, Y.; Cabaraux, A.; Marechal, F.; Losson, B. Swimmer's Itch in Belgium: First Recorded Outbreaks, Molecular Identification of the Parasite Species and Intermediate Hosts. Vector-Borne Zoonotic Dis. 2017, 17, 190-194. [CrossRef] [PubMed]

593. Lawton, S.P.; Lim, R.M.; Dukes, J.P.; Cook, R.T.; Walker, A.J.; Kirk, R.S. Identification of a major causative agent of human cercarial dermatitis, Trichobilharzia franki (Muller and Kimmig 1994), in southern England and its evolutionary relationships with other European populations. Parasit Vectors 2014, 7, 277. [CrossRef] [PubMed]

594. Kolarova, L.; Horak, P.; Skirnisson, K.; Mareckova, H.; Doenhoff, M. Cercarial dermatitis, a neglected allergic disease. Clin. Rev. Allergy Immunol. 2013, 45, 63-74. [CrossRef] [PubMed]

595. Brant, S.V.; Loker, E.S. Schistosomes in the southwest United States and their potential for causing cercarial dermatitis or 'swimmer's itch'. J. Helminthol. 2009, 83, 191-198. [CrossRef] [PubMed]

596. Valdovinos, C.; Balboa, C. Cercarial dermatitis and lake eutrophication in south-central Chile. Epidemiol. Infect. 2008, 136, 391-394. [CrossRef] [PubMed]

597. Schets, F.M.; Lodder, W.J.; van Duynhoven, Y.T.; de Roda Husman, A.M. Cercarial dermatitis in the Netherlands caused by Trichobilharzia spp. J. Water Health 2008, 6, 187-195. [CrossRef] [PubMed]

598. Kolarova, L. Schistosomes causing cercarial dermatitis: A mini-review of current trends in systematics and of host specificity and pathogenicity. Folia Parasitol. 2007, 54, 81-87. [CrossRef] [PubMed]

599. Kolarova, L.; Gottwaldova, V.; Cechova, D.; Sevcova, M. The occurrence of cercarial dermatitis in Central Bohemia. Zentralbl. Hyg. Umweltmed. 1989, 189, 1-13. [PubMed]

600. Ranjbar, R.; Rahbar, M.; Naghoni, A.; Farshad, S.; Davari, A.; Shahcheraghi, F. A cholera outbreak associated with drinking contaminated well water. Arch. Iran. Med. 2011, 14, 339-340. [PubMed]

601. Mridha, P.; Biswas, A.K.; Ramakrishnan, R.; Murhekar, M.V. The 2010 outbreak of cholera among workers of a jute mill in Kolkata, West Bengal, India. J. Health Popul. Nutr. 2011, 29, 9-13. [CrossRef] [PubMed]

602. Bhunia, R.; Ramakrishnan, R.; Hutin, Y.; Gupte, M.D. Cholera outbreak secondary to contaminated pipe water in an urban area, West Bengal, India, 2006. Indian J. Gastroenterol. 2009, 28, 62-64. [CrossRef] [PubMed]

603. De Magny, G.C.; Thiaw, W.; Kumar, V.; Manga, N.M.; Diop, B.M.; Gueye, L.; Kamara, M.; Roche, B.; Murtugudde, R.; Colwell, R.R. Cholera outbreak in Senegal in 2005: Was climate a factor? PLoS ONE 2012, 7, e44577. [CrossRef]

604. Goel, A.K.; Jiang, S.C. Association of Heavy Rainfall on Genotypic Diversity in V. cholerae Isolates from an Outbreak in India. Int. J. Microbiol. 2011, 2011, 230597. [CrossRef] [PubMed]

605. Martinez-Urtaza, J.; Huapaya, B.; Gavilan, R.G.; Blanco-Abad, V.; Ansede-Bermejo, J.; Cadarso-Suarez, C.; Figueiras, A.; Trinanes, J. Emergence of Asiatic Vibrio diseases in South America in phase with El Nino. Epidemiology 2008, 19, 829-837. [CrossRef] [PubMed] 
606. Oberbeckmann, S.; Fuchs, B.M.; Meiners, M.; Wichels, A.; Wiltshire, K.H.; Gerdts, G. Seasonal dynamics and modeling of a Vibrio community in coastal waters of the North Sea. Microb. Ecol. 2012, 63, 543-551. [CrossRef] [PubMed]

607. Constantin de Magny, G.; Murtugudde, R.; Sapiano, M.R.; Nizam, A.; Brown, C.W.; Busalacchi, A.J.; Yunus, M.; Nair, G.B.; Gil, A.I.; Lanata, C.F.; et al. Environmental signatures associated with cholera epidemics. Proc. Natl. Acad. Sci. USA 2008, 105, 17676-17681. [CrossRef] [PubMed]

608. Huq, A.; Sack, R.B.; Nizam, A.; Longini, I.M.; Nair, G.B.; Ali, A.; Morris, J.G., Jr.; Khan, M.N.; Siddique, A.K.; Yunus, M.; et al. Critical factors influencing the occurrence of Vibrio cholerae in the environment of Bangladesh. Appl. Environ. Microbiol. 2005, 71, 4645-4654. [CrossRef] [PubMed]

609. Dziuban, E.J.; Liang, J.L.; Craun, G.F.; Hill, V.; Yu, P.A.; Painter, J.; Moore, M.R.; Calderon, R.L.; Roy, S.L.; Beach, M.J.; et al. Surveillance for waterborne disease and outbreaks associated with recreational water-United States, 2003-2004. Morb. Mortal. Wkly. Rep. Surveill. Summ. 2006, 55, 1-30.

610. Shaw, K.S.; Sapkota, A.R.; Jacobs, J.M.; He, X.; Crump, B.C. Recreational swimmers' exposure to Vibrio vulnificus and Vibrio parahaemolyticus in the Chesapeake Bay, Maryland, USA. Environ. Int. 2015, 74, 99-105. [CrossRef] [PubMed]

611. Paz, S.; Bisharat, N.; Paz, E.; Kidar, O.; Cohen, D. Climate change and the emergence of Vibrio vulnificus disease in Israel. Environ. Res. 2007, 103, 390-396. [CrossRef] [PubMed]

612. Wallace, B.J.; Guzewich, J.J.; Cambridge, M.; Altekruse, S.; Morse, D.L. Seafood-associated disease outbreaks in New York, 1980-1994. Am. J. Prev. Med. 1999, 17, 48-54. [CrossRef]

613. Esteves, K.; Hervio-Heath, D.; Mosser, T.; Rodier, C.; Tournoud, M.G.; Jumas-Bilak, E.; Colwell, R.R.; Monfort, P. Rapid proliferation of Vibrio parahaemolyticus, Vibrio vulnificus, and Vibrio cholerae during freshwater flash floods in French Mediterranean coastal lagoons. Appl. Environ. Microbiol. 2015, 81, 7600-7609. [CrossRef] [PubMed]

614. Banakar, V.; Constantin de Magny, G.; Jacobs, J.; Murtugudde, R.; Huq, A.; Wood, R.J.; Colwell, R.R. Temporal and spatial variability in the distribution of Vibrio vulnificus in the Chesapeake Bay: A hindcast study. Ecohealth 2011, 8, 456-467. [CrossRef] [PubMed]

615. Inoue, Y.; Miyasaka, J.; Ono, T.; Ihn, H. The growth of Vibrio vulnificus and the habitat of infected patients in Kumamoto. Biosci. Trends 2007, 1, 134-139. [PubMed]

616. Fuenzalida, L.; Armijo, L.; Zabala, B.; Hernandez, C.; Rioseco, M.L.; Riquelme, C.; Espejo, R.T. Vibrio parahaemolyticus strains isolated during investigation of the summer 2006 seafood related diarrhea outbreaks in two regions of Chile. Int. J. Food Microbiol. 2007, 117, 270-275. [CrossRef] [PubMed]

617. McLaughlin, J.B.; DePaola, A.; Bopp, C.A.; Martinek, K.A.; Napolilli, N.P.; Allison, C.G.; Murray, S.L.; Thompson, E.C.; Bird, M.M.; Middaugh, J.P. Outbreak of Vibrio parahaemolyticus gastroenteritis associated with Alaskan oysters. N. Engl. J. Med. 2005, 353, 1463-1470. [CrossRef] [PubMed]

618. Meusburger, S.; Reichart, S.; Kapfer, S.; Schableger, K.; Fretz, R.; Allerberger, F. Outbreak of acute gastroenteritis of unknown etiology caused by contaminated drinking water in a rural village in Austria, August 2006. Wien. Klin. Wochenschr. 2007, 119, 717-721. [CrossRef] [PubMed]

619. Inoue, M.; Nakashima, H.; Ishida, T.; Tsubokura, M. Three outbreaks of yersinia pseudotuberculosis infection. Zentralbl. Bakteriol. Mikrobiol. Hyg. B 1988, 186, 504-511. [PubMed]

620. Thompson, J.S.; Gravel, M.J. Family outbreak of gastroenteritis due to Yersinia enterocolitica serotype 0:3 from well water. Can. J. Microbiol. 1986, 32, 700-701. [CrossRef] [PubMed]

621. Kozisek, F.; Jeligova, H.; Dvorakova, A. Waterborne diseases outbreaks in the Czech Republic, $1995-2005$. Epidemiol. Mikrobiol. Imunol. 2009, 58, 124-131. [PubMed]

622. Schuster, C.J.; Ellis, A.G.; Robertson, W.J.; Charron, D.F.; Aramini, J.J.; Marshall, B.J.; Medeiros, D.T. Infectious disease outbreaks related to drinking water in Canada, 1974-2001. Can. J. Public Health 2005, 96, 254-258. [PubMed]

623. Eregno, F.E.; Tryland, I.; Tjomsland, T.; Myrmel, M.; Robertson, L.; Heistad, A. Quantitative microbial risk assessment combined with hydrodynamic modelling to estimate the public health risk associated with bathing after rainfall events. Sci. Total Environ. 2016, 548-549, 270-279. [CrossRef] [PubMed]

(C) 2018 by the authors. Licensee MDPI, Basel, Switzerland. This article is an open access article distributed under the terms and conditions of the Creative Commons Attribution (CC BY) license (http:/ / creativecommons.org/licenses/by/4.0/). 